I N T ER N ATIONAL MONETARY FUND

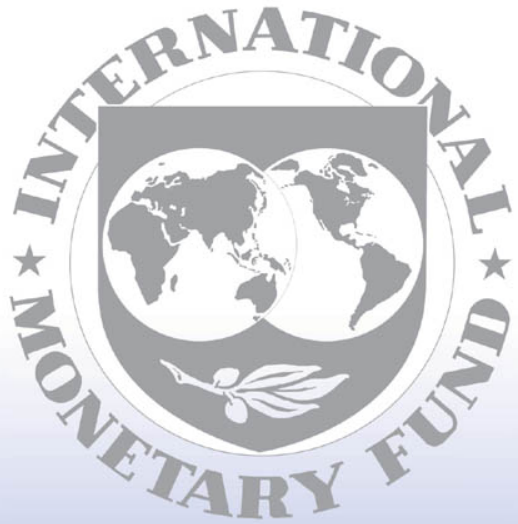

Staff

Country

Reports 


\section{Panama: Recent Economic Developments}

This Recent Economic Developments paper on Panama was prepared by a staff team of the International Monetary Fund as background documentation for the periodic consultation with the member country. It is based on the information available at the time it was completed on January 5, 2001. The views expressed in this document are those of the staff team and do not necessary reflect the views of the government of Panama or the Executive Board of the IMF.

The policy of publication of staff reporis and other documents by the IMF allows for the deletion of market-sensitive information.

To assist the IMF in evaluating the publication policy, reader comments are invited and may be sent by e-mail to Publicationpolicy@imf.org.

Copies of this report are available to the public from International Monetary Fund - Publication Services

70019 th Street, N.W. - Washington, D.C. 20431

Telephone: (202) 6237430 - Telefax: (202) 6237201

E-mail: publications@imf.org - Internet; http://www.imf.org

Price: $\$ 15.00$ a copy

\section{International Monetary Fund Washington, D.C.}


PANAMA

\section{Recent Economic Developments}

Prepared by G.A. Mackenzie (Head), G. Bindley-Taylor, M. Gapen, A. Gómez-Oliver, C. Paiva, M. Papaioannou (all WHD) and M. Moore (MAE)

Approved by the Western Hemisphere Department

January 5,2001

Contents

Basic Data. 4

Introduction 6

I. Review of Recent Economic Developments

A. Summary of Developments.

B.

C.

D. Aggregate Supply and Demand, Employment and Prices ........................... 7

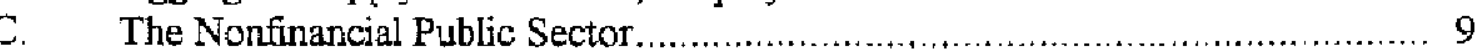

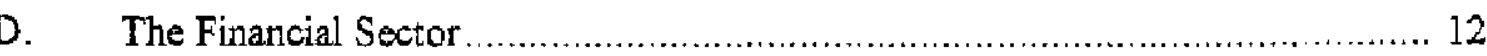

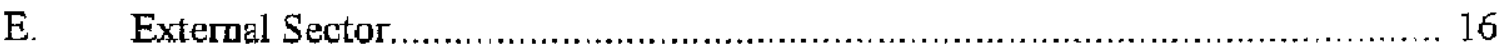

II. The Panama Canal and the Reverted Areas - An Update ..................................... 19

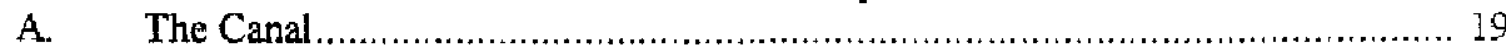

B. Development \$trategy and Economic Impact of the Reverted Areas ............. 21

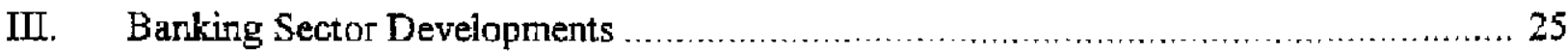

A. Introduction and Background on Recent Events .................................... 25

B. Structure of the Banking System and Current Banking Conditions ................. 25

C. Developments in Supervision and Regulation....................................... 30

D. Private Banking and Anti-Money Laundering Measures .............................. 33

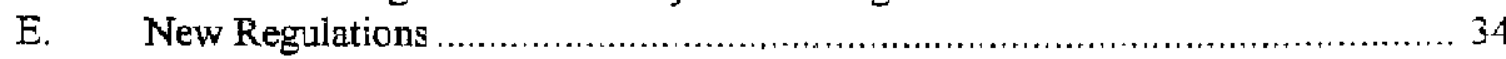

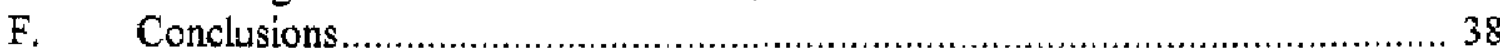

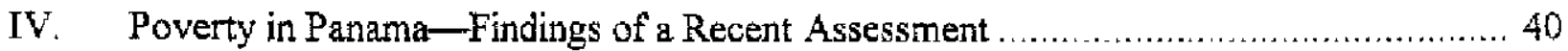

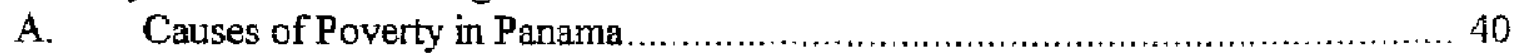

B. Poverty Reduction Strategy and Reform ............................................ 42 
Text Tables

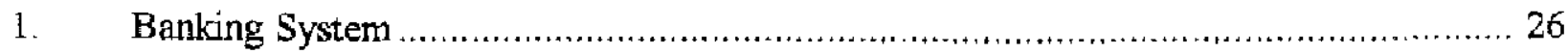

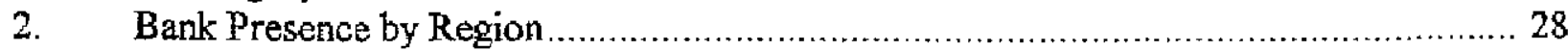

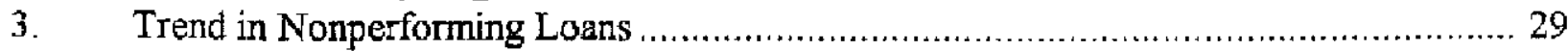

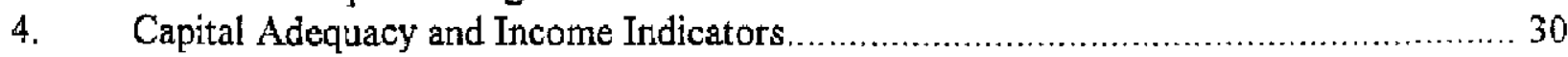

\section{Statistical Appendix Tables}

5. National Accounts by Productive Activity ........................................................ 44

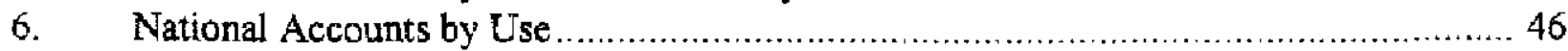

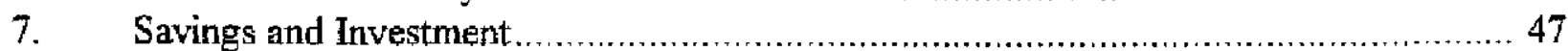

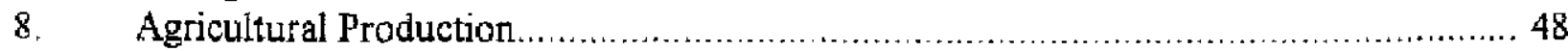

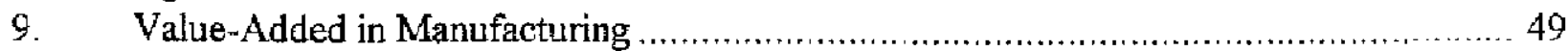

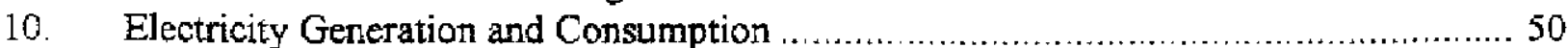

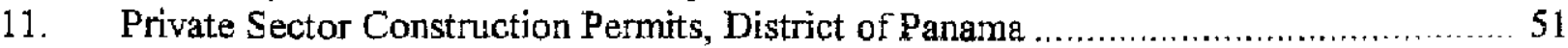

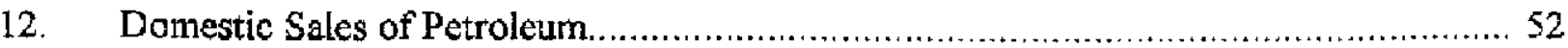

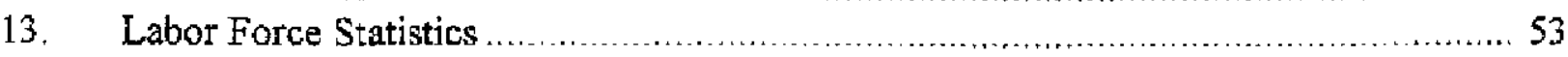

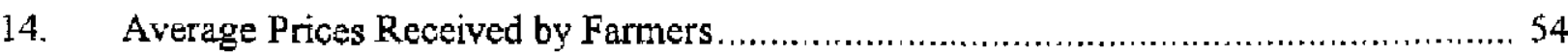

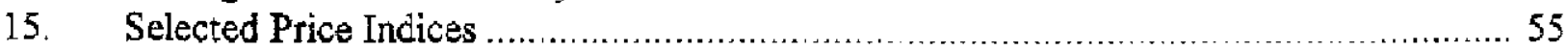

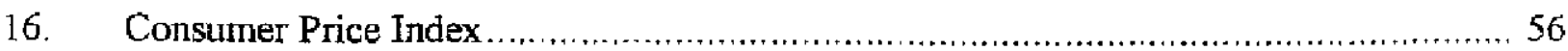

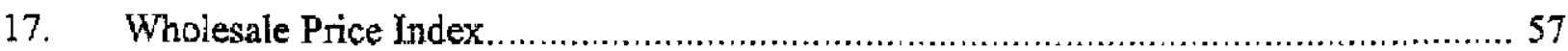

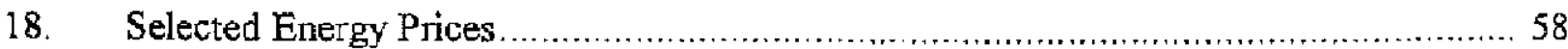

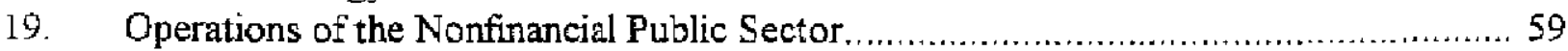

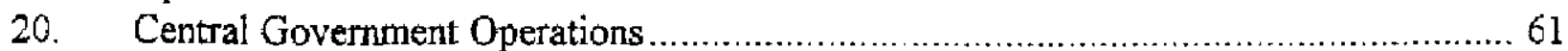

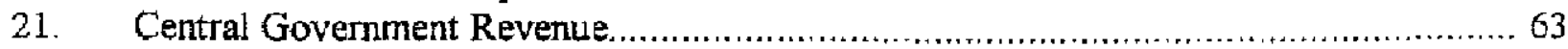

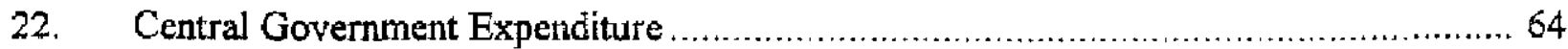

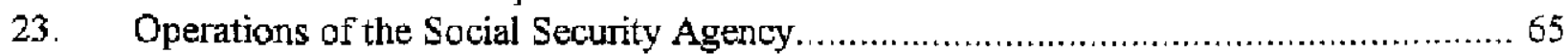

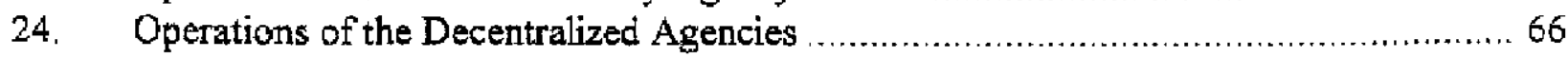

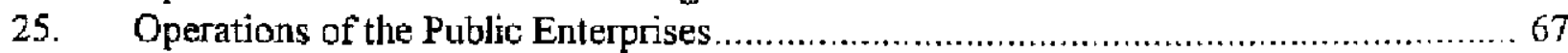

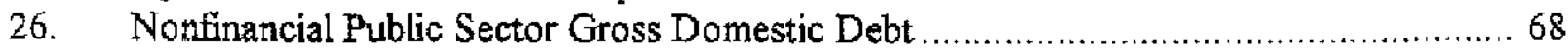

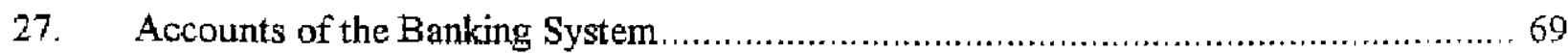

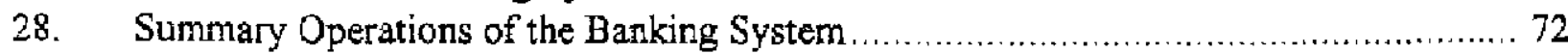

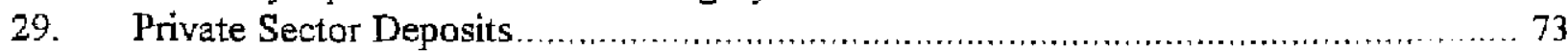

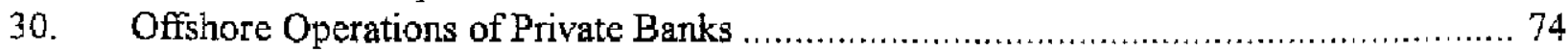

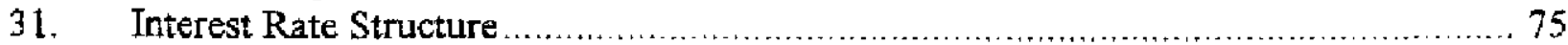

32. Banking System Credit to the Domestic Private

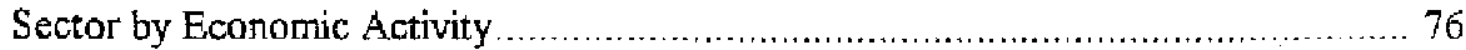

33. Public Sector Banks_-Operating Revenue and Expenditure $\ldots \ldots \ldots \ldots \ldots \ldots \ldots \ldots \ldots \ldots \ldots \ldots .77$

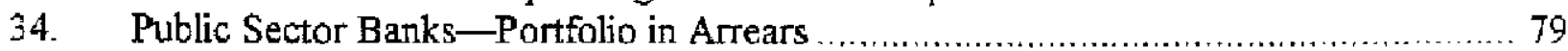

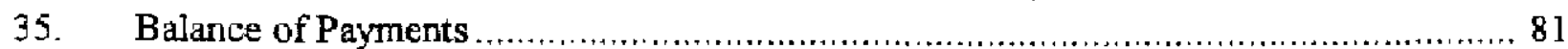

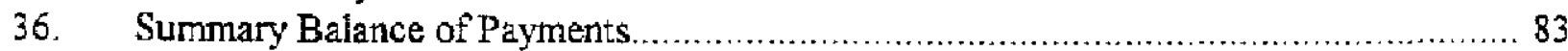

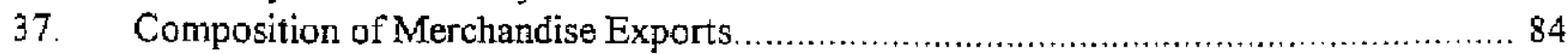

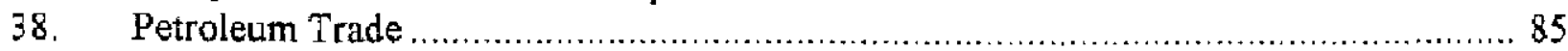

39. Nontraditional Exports and Issue of Tax Credit Certificates ............................... 86

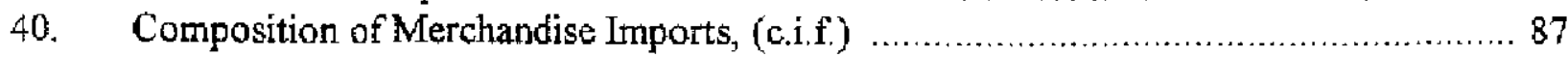

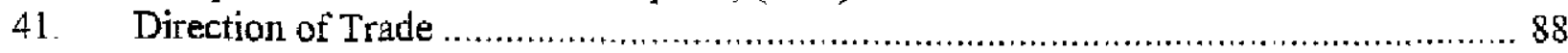




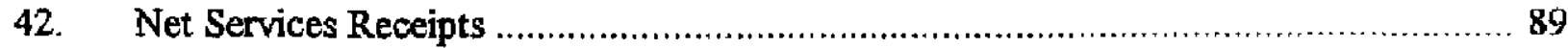

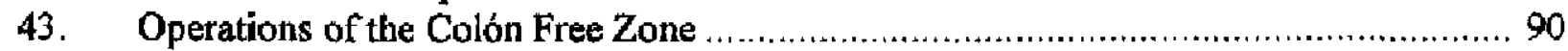

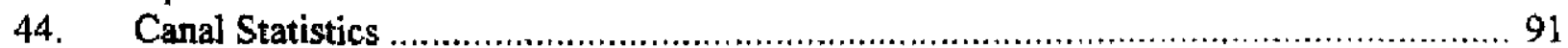

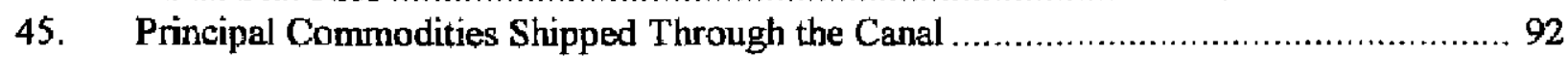

46. Travel Receipts and Expenditure, and Number of Visitors ................................ 93

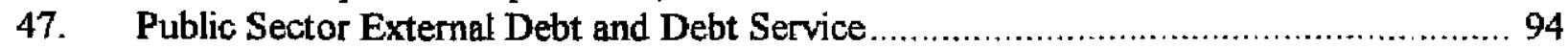

48, External Public Debt Indicators .................................................................... 95

49. Operations on Medium- and Long-Term External Debt of the Nonfinancial

Public Sector Classified by Creditor ............................................................ 96

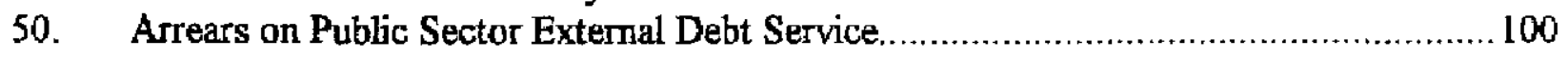


Panama: Basic Data

I. Social and Demographic Indicators

$\begin{array}{lr}\text { Area (thousand sq. km) } & 77,082 \\ & \\ \text { Population } & 2.9 \\ \text { Total (million) (est., 2000) } & 1.6 \\ \text { Rate of increase (percent a year) } & 38 \\ \text { Density (per sq. lm.) } & 3,395 \\ \text { GDP per capita (US\$) (1999) } & 13.3 \\ \text { Unemployment (Aug. 2000) } & \\ & \\ \text { Population characteristics (1999) } & 75.5 \\ \text { Iife expectancy at birth (years) } & 19.5 \\ \text { Crude birth rate (per thousand) } & 5.0 \\ \text { Crude death rate (per thousand) } & \\ \text { Infant mortality (per thousand live birt } & 20.8 \\ & \\ \text { Income distribution (1999) } & \\ \text { By highest 20 percent of households } & 63 \\ \text { By lowest 20 percent of households } & 2\end{array}$

Health (1994)

Per capita calorie intake $\quad 2,534$

2.9

Population

Per physictan (1995) 592

1.6
38

3,395

Per hospital bed (1996) 455

Access to safe water (percent

of population, 1998)

Total 84

Urban 92

19.5

Rural 72

Education (in percent, 1997)

Net Eurollment rates

Primary education $\quad 92$

Secondary education 62

Higher education

GDP (1999) US $\$ 9,545$ million

II. Economic Indicators, $1996-2000$

\begin{tabular}{|c|c|c|c|c|c|}
\hline & 1996 & 1997 & 1998 & $\begin{array}{r}\text { Revised } \\
1999 \\
\end{array}$ & $\begin{array}{l}\text { Proj. } \\
2000\end{array}$ \\
\hline \multicolumn{6}{|c|}{ (In percent change) } \\
\hline $\begin{array}{l}\text { National accounts and prices } \\
\text { GDP at constant } 1982 \text { market prices } \\
\text { Agriculture and mining } \\
\text { Manufacturing and construction } \\
\text { Services } \\
\text { Consurner price index (end-of-period) }\end{array}$ & $\begin{array}{r}2.8 \\
0.8 \\
-2.1 \\
4.2 \\
2.3\end{array}$ & $\begin{array}{r}4.5 \\
1.2 \\
6.1 \\
4.8 \\
-0.5\end{array}$ & $\begin{array}{l}4.4 \\
6.8 \\
4.7 \\
4.7 \\
1.4\end{array}$ & $\begin{array}{r}3.0 \\
-0.3 \\
0.6 \\
4.7 \\
1.5\end{array}$ & $\begin{array}{r}2.3 \\
-2.3 \\
-6.7 \\
4.7 \\
2.0\end{array}$ \\
\hline $\begin{array}{l}\text { Monstary } 1 / \\
\text { Net Domestic assets } \\
\text { Credit to the public sector } \\
\text { Credit to the private sector } \\
\text { Liabilities to the domestic private sector }\end{array}$ & $\begin{array}{l}5.0 \\
2.5 \\
7.0 \\
8.1\end{array}$ & $\begin{array}{l}10.3 \\
2.0 \\
12.5 \\
15.4\end{array}$ & $\begin{array}{r}17.8 \\
-1.2 \\
21.9 \\
12.4\end{array}$ & $\begin{array}{r}18.0 \\
-0.7 \\
17.4 \\
7.6\end{array}$ & $\begin{array}{r}12.0 \\
-0.1 \\
13.1 \\
9.1\end{array}$ \\
\hline \multicolumn{5}{|c|}{ (In percent of GDP) 3 / } &. \\
\hline $\begin{array}{l}\text { Investment and saving } \\
\text { Gross domestic investment } \\
\text { Private investment } \\
\text { Gross national savings } \\
\text { Private saving. }\end{array}$ & $\begin{array}{l}30.5 \\
26.7 \\
26.8 \\
22.8\end{array}$ & $\begin{array}{l}31.1 \\
26.6 \\
24.3 \\
21.3\end{array}$ & $\begin{array}{l}32.8 \\
26.4 \\
19.7 \\
17.3\end{array}$ & $\begin{array}{l}32.5 \\
27.8 \\
18.2 \\
15.3\end{array}$ & $\begin{array}{l}30.2 \\
26.5 \\
19.8 \\
17.6\end{array}$ \\
\hline $\begin{array}{l}\text { Nonfinancial public sector } \\
\text { Revenue and Grants } \\
\text { Expenditure } \\
\text { Current } \\
\text { Capital. } \\
\text { Primary balance } \\
\text { Overall balance }\end{array}$ & $\begin{array}{r}28.0 \\
27.5 \\
23.7 \\
3.8 \\
3.8 \\
0.5\end{array}$ & $\begin{array}{r}28.7 \\
28.9 \\
24.5 \\
4.3 \\
3.5 \\
-0.2\end{array}$ & $\begin{array}{r}28.3 \\
31.3 \\
25.0 \\
6.4 \\
1.0 \\
-3.0\end{array}$ & $\begin{array}{r}29.2 \\
30.7 \\
25.9 \\
4.8 \\
2.5 \\
-3.4\end{array}$ & $\begin{array}{r}28.7 \\
29.8 \\
26.1 \\
3.7 \\
3.0 \\
-1.1\end{array}$ \\
\hline External current account & -3.7 & -6.8 & -13.1 & -14.4 & -10.4 \\
\hline $\begin{array}{l}\text { Gross public debt } \\
\text { External } \\
\text { Domestic }\end{array}$ & $\begin{array}{l}77.2 \\
62.0 \\
15.2\end{array}$ & $\begin{array}{l}71.9 \\
57.8 \\
14.1\end{array}$ & $\begin{array}{l}69.7 \\
58.5 \\
11.2\end{array}$ & $\begin{array}{l}72.8 \\
58.3 \\
14.4\end{array}$ & $\begin{array}{l}72.3 \\
57.9 \\
14.4\end{array}$ \\
\hline
\end{tabular}


Panama: Basic Data

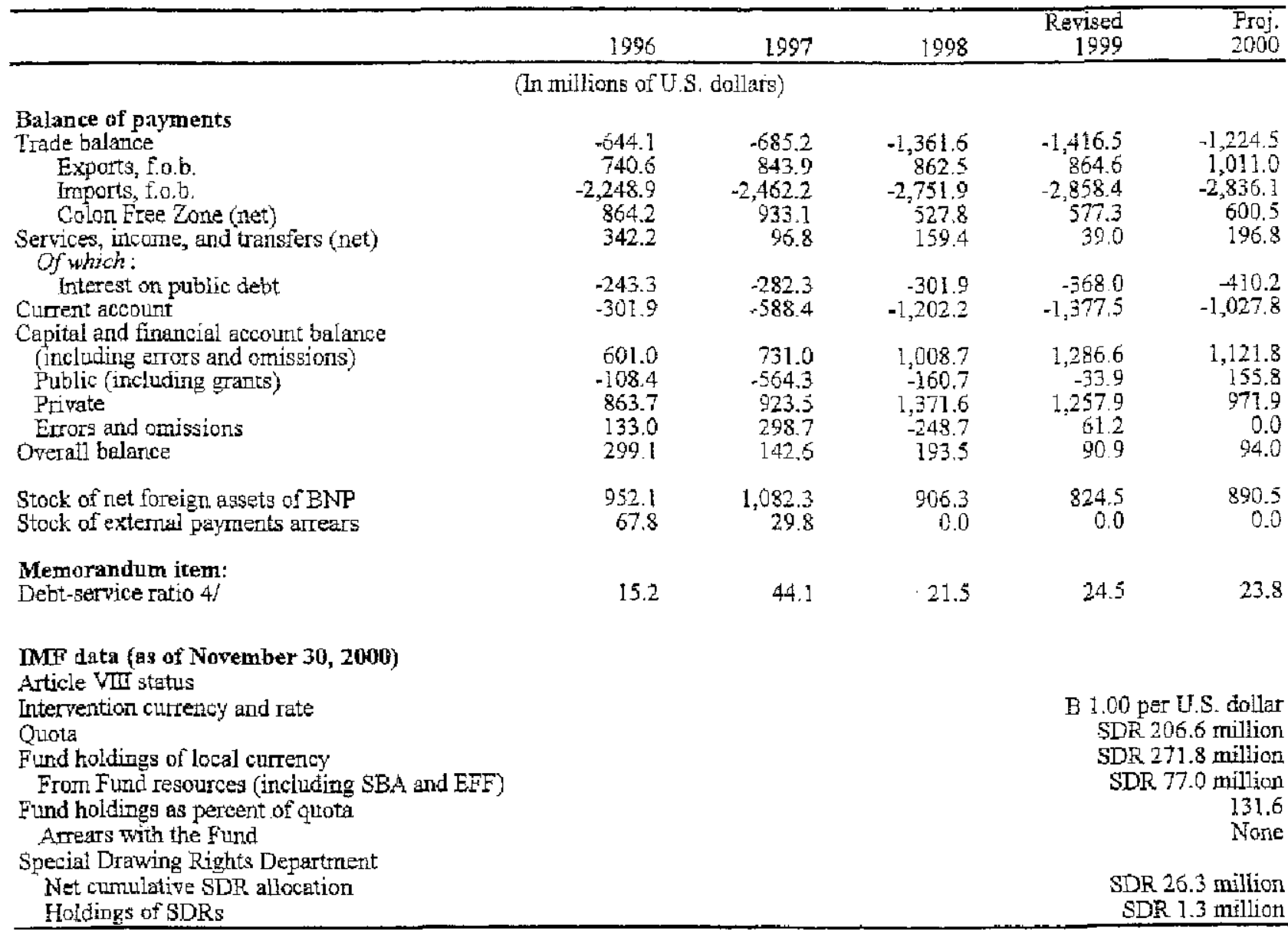

Sources: Panamanian authorities; and Fund staff estimates.

If In percent of initial stock of liabilities to the private sector.

2/ Based on the period average.

3/ Reflects the authorities' revisions to nominel GDP.

4/ Extemal debt service as percent of exports of goods and services. In 1997 the increase reflects debt restructiring involving the retirement of Brady bonds. 


\section{INTRODUCTION}

1. This report provides background information and supporting analyses for the staff report for the 2000 Article IV consuitation discussions with Panama. Chapter I presents an overview of economic developments since 1998. Chapter II summarizes the financial and economic aspects of the operation of the Panama Canal and discusses the economic impact of the reversion of the Canal and its adjacent areas to Panama. Chapter III describes the progress of bank supervisory teform. Finally, Chapter IV briefly discusses poverty and poverty alleviation programs.

\section{REVIEW OF RECENT ECONOMIC DEVELOPMENTS}

\section{A. Summary of Developments}

2. Real GDP growth fełl to an estimated 2.3 percent in 2000 from 4.4 percent in 1998 and 3.0 percent in 1999. The decline in growth is mainly attributable to the repercussions on the re-exports of the Colón Free Zone (ZLC) of economic difficulties in trading partner countries, and the impact of disease and drought on fishing and agriculture. It does not reflect a decline in the underlying rate of economic growth. Despite the decline in the value added of the ZLC, the service sector, which accounts for about 80 percent of GDP, continued to grow quite steadily at 4.7 percent per year.

3. The unemployment rate fell from 13.4 percent in 1997 to 11.8 percent in 1999 before increasing to 13.3 percent in 2000 . The increase in the CPI averaged about $1 \frac{1}{2}$ percent per year with little fluctuation despite the increase in world oil prices since March 1999.

4. Public sector finances weakened in the second half of 1998 because of electionrelated capital spending by the central government. As a result, the borrowing requirement of the nonfinancial public sector (the PSBR) rose from 0.3 percent of GDP in 1997 to 2.9 percent in 1998. Efforts to restrain central government expenditure reduced the PSBR to 1.4 percent of GDP in 1999. Restraint of capital expenditure is projected to lower the PSBR to 1.1 percent of GDP in 2000 despite a slowdown in revenue growth brought on by the decline in economic growth.

5. Substantial progress was achieved in reducing the size of the nonfinancial public enterprise sector in 1996-98, and in establishing regulatory bodies to promote competition. In 1998-00, however-apart from bank regulatory reform (discussed in Chapter II)--the pace of structural reform slackened. In particular, there were no further privatizations, and tax and social security reform did not advance. Nonetheless, the privatized complementary fund for civil servants began operations in 1998 and some progress was achieved in the development of the automated public financial information system, SIAFPA. ${ }^{1}$

\footnotetext{
${ }^{1}$ SIAFPA stands for "Sistema Integrado Automático Financiero de Panama."
} 
6. Bank credit to the domestic economy grew rapidly in 1998-00, and the domestic business of the general license banks-those allowed to deal with tesidents-is now greater than their international business. The growth of credit outstripped the growth of deposits, requiring that the banks reduce substantially their net foreign asset position. The credit growth financed private sector investment projects related to the reversion and investments by households in housing and consumer durables. Net bank credit to the public sector declined.

7. The externai current account deficit increased from about 6.8 percent of GDP in 1997 to an average of 13.8 percent of GDP in 1998-99 (it is estimated to have declined to 10.4 percent of GDP in 2000). An increase in the trade deficit of 7.0 percent of GDP and an increase in net factor income payments of 2.0 percent of GDP outweighed an increase in the surplus on services. The drop in the net exports of the ZLC and an increase in imports related to the investment boom and easy terms for consumer credit explain most of the deterioration of the trade balance. The increase in the current account deficit in 1997-99 was mirrored by an increase in the private sector's financing requirement of 7.0 percent.

8. The current account deficits were financed entirely by the private sector in 1998-00. Net public capital inflows (including changes in public sector deposits abroad) were negative in these years. Public external debt remained at about 59 percent of GDP.

\section{B. Aggregate Supply and Demand, Employment and Prices}

9. The growth of real GDF fell from 4.5 percent in 1997 to 3.0 percent in 1999 , and is estimated to have declined to 2.3 percent in 2000 . The stowdown was mainly attributable to the impact of economic difficulties in Brazil, Colombia, Ecuador, and Venezuela on net exports of the ZLC. ${ }^{2}$ Specifically, the ZLC's net exports fell from US\$933 million in 1997 to US\$577 million in 1999, and are estimated to have risen to US\$600 million in 2000 . Severe declines in agriculture and fishing output also contributed. ${ }^{3}$ In contrast, the service sector, and in particular financial intermediation and telecommunications grew strongly, construction activity was stimulated by investments in the reverted areas and some large public works projects in 1998--99, and electricity output recovered from the effects of the El Niño-related drought in 1998. The growth rate of the service sector has been relatively constant in recent years and has contributed to the overall stability of economic growth given its large contribution to output. ${ }^{4}$

${ }^{2}$ These four countries account for 44 percent of the ZLC's exports.

${ }^{3}$ Primary activity, including agriculture and mining, accounts for approximately 8 percent of GDP. Manufacturing and construction account for 12 percent.

${ }^{4}$ The reversion of the Canal at end-1999 and the closure of the U.S. military bases in the adjacent areas entailed a loss of income from employment on the bases and the sale of goods 
10. Domestic demand increased much more rapidly than supply from 1997-99, and the deficit on external current account increased from 6.8 percent of GDP in 1997 to 14.4 percent of GDP in 1999, before declining to an estimated 10.4 percent of GDP in 2000 . The increase in the current account was mirrored by an increase in the private sector"s financing requirement (investment minus saving) of 7 percent of GDP. In particular, private sector saving declined steeply from 21.3 percent of GDP in 1997 to 15.3 percent of GDP in 1999, in part because banks were extending consumer loans on more liberal terms than previously. Private sector investment increased from the already high level of 26.6 percent of GDP in 1997 to 27.8 percent in 1999 because of investment in the reverted areas and other projects already noted. It is estimated to have declined to 26.5 percent of GDP in 2000 . Much of the increase in fixed investment since the mid-1990s was financed by direct foreign investment.

11. On the basis of estimates through the third quarter, the rate of growth of GDP fell to 2.3 percent in 2000 compared with the program projection of 3.8 percent. Growth in services remained robust, and the $Z$ LLC began to recover from its slump, but construction, farming and fishing, and related food-processing industries experienced unexpectedly large declines. The completion of several large infrastructure projects reduced construction activity by more than expected, while the lingering effects of disease on the shrimp harvest and a change in the European Union (EU) trading preferences on banana production were unexpectedly strong.

12. The rate of unemployment fell from an average of 13.5 percent in $1997-98$ to 11.8 percent in 1999 before rising again to 13.3 percent in 2000 . From 1997 to 2000 , the growth rate of the labor force was 3.5 percent and the growth rate in overall employment was 3.6 percent. The labor force participation rate declined from 61.5 percent to 59.9 percent over the same period.

13. The share of employment in the primary and secondary sectors in total employment continued to decline in 1997-00. Specifically, the share of agriculture and mining employment in the total fell from 18.9 percent in 1997 to 17.3 percent in 2000 .

Manufacturing employment's share declined from 10.6 percent to 9.1 percent. In contrast, the share of employment in services including commerce, transportation and communications grew from 63.0 percent in 1997 to 65.5 percent in 2000 .

14. Despite the impact of increases in world petroleum prices on domestic gasoline and other petroleum products, inflation remained low and stable, reflecting Panama's monetary arrangements. The average annual rates of increase in the consumer price index in 1994-00

and other services of about US $\$ 130$ million (1.4 percent of GDP). However, the phasing out of the U.S. military presence had been expected for some time, and the reversion was already stimulating substantial investment in ports and other facilities (see Chapter II).

5 The quarterly GDP estimates for the first three quarters of 2000 are product-side only. There are no estimates of the components of demand. 
have ranged from $0.6-1.5$ percent. The 12 -month inflation rate in November 2000 was 1.1 percent.

\section{The Nonfinancial Public Sector}

\section{The structure of the nonfinancial public sector}

15. Panama's monitored nonfinancial public sector (NFPS) comprises the central. government, the social security agency (CSS), a number of decentralized agencies, and several public enterprises. Total NFPS revenues and grants are equivalent to about 29 percent of GDP, whereas total expenditures amount to some 30 percent of GDP. The central government is the dominant entity in the NFPS, responding for approximately 65 percent of total revenues and 60 percent of total expenditures of the NFPS. As its second largest entity, the CSS accounts for about 27 percent of total NFPS revenues and expenditures. ${ }^{6}$

16. In addition to all ministries and offices of the direct central administration, the central government is defined to also include the Provincial Councils, the Legislative Assembly, the Supreme Court, and the Electoral Court. The nine Provincial Councils are local administration bodies with largely advisory responsibilities, as provincial governments have little autonomy and are under direct control of the central government. ${ }^{7}$ Although they are not included in the monitored public sector, municipalities collect a small share of the public sector revenues through some taxes and fees, and some small municipalities depend on transfers from the national government to finance their expenditures. Many functions that fall within the jurisdiction of local governments in other nations-such as education, the judiciary, and police administration-are the responsibility of the central government in Panama.

17. The CSS administers old-age and disability retirement plans, health insurance, workrelated accident and other work benefits. It covers about 60 percent of Panama's population, including some 550,000 active contributors, more than 100,000 pensioners, and about 1 million dependents. About 80 percent of the CSS's revenue curtently comes from payroll taxes. Most of the remaining revenue comes from earnings on CSS's accumulated surplus, which is invested in government securities and near-cash instruments, including deposits with the BNP. The CSS also receives some transfers from the central government, amounting to 0.4 percent of GDP to cover administrative costs.

\footnotetext{
${ }^{6}$ In the case of public enterprises, revenues are reported net of operating expenses.

${ }^{7}$ Each Provincial Governor is appointed and can be freely removed by the President.

${ }^{8}$ In 1999 , municipalities' revenues and expenditures were about 0.7 percent of GDP.
} 
18. The main decentralized agencies are the University of Panama, the Agriculture Development Bank (BDA), and the National Mortgage Bank (BHN). ${ }^{9}$ The decentralized agencies finance their operations mainly by means of transfers from the central govenment. Although the BDA and the BHN are formally public financial institutions, their role as quasifiscal agents justify their inclusion in the NFPS. The University of Panama has the largest budget of the decentralized agencies (corresponding to about 60 percent of the total) and receives most of the government transfers, reflecting a policy of heavily subsidizing tertiary education in public institutions.

19. The privatization program carried out during the second half of the $1990 \mathrm{~s}$ substantially reduced the size of the nonfinancial public enterprise sector in Panama. The main enterprises remaining in the NFPS are the Electricity Transmission Company (ETESA), the National Water and Sewerage Company (DAAN), and the Colon Free Zone Operating Agency. Despite some operational inefficiencies, especially at DAAN, the monitored public enterprise sector has generated consistent-albeit declining-operating surpluses. A large share of these surpluses has been transferred to the central government.

\section{Developments in 1998-99}

20. Fiscal performance in 1998-99 was mixed. The overall deficit of the NFPS increased from 0.3 percent of GDP in 1997 to 2.9 percent of GDP in 1998, substantially exceeding the deficit of 0.7 percent of GDP targeted in the program supported under the EFF. The swings in the NFPS basically reflect developments at the central government. In particular, most of the increase in the deficit can be attributed to central government capital expenditure overruns in the run-up to the presidential election of May 1999. A significant fiscal tightening took place in 1999 , mainly through outs in investment and increased tax collection. Although the adjustment reduced the overall NFPS deficit to 1.4 percent of GDP, the target of the EFF-supported program was exceeded by 0.4 percent of GDP. Net public sector debt increased from 47.2 percent of GDP in 1998 to 50.7 percent of GDP in 1999. This increase is attributable to the issuance of bonds by the government to recognize past unfunded civil service pension obligations transferred to the newly formed private plan, SIACAP. ${ }^{10}$

21. The increase in capital expenditures already noted was the main force behind the increase in the deficit of the central government from zero in 1997 to 5.0 percent of GDP in 1998. In addition, pensions and transfer payments increased sharply with the settlement of

The remaining decentralized agencies included in the monitored public sector are the Instituto de Mercadeo Agropecuario (agriculture support) and the Instituto para la Formación y Aprovechamiento de los Recursos Humanos (professional training).

${ }^{10}$ SIACAP stands for Sistema de Ahorros y Capitalización de Pensiones de los Servidores Públicos. 
arrears to the CSS. ${ }^{11}$ The deficit was reduced to 2.4 percent of GDP in 1999 , with expenditure retrenchment accounting for most of the adjustment. In addition to the decrease in pension paymeats from the extraordinarily high levels of 1998, capital expenditures were reduced by about one percent of GDP in 1999. Revenues benefited from a large transfer of profits from the Banco Nacional de Panamá, increased tolls and dividends from the Panama Canal, and higher income tax collection attributable mainly to changes in the legislation that closed loopholes and reduced the exemptions granted to some business activities. Tolls and dividends received from the Canal increased as a consequence of the impending reversion of the Canal to Panamanian administration. American workers had additional benefits for living abroad, and as the work force became increasingly dominated by locals, labor costs declined. These cost savings permitted an increase in the central government's share of Canal revenues.

22. The CSS posted a surplus of about 2.6 percent of GDP in 1998 , mostly explained by the extraordinary transfers received from the central government. Nonetheless, the CSS's financial position exciuding transfers also improved in 1998 , reflecting some administrative gains in the collection of contributions and a slowdown in the increase of benefit payments. In 1999, the overall surplus of the CSS was equivalent to about 0.9 percent of GDP, as central goverument transfers declined from 1998 levels, but the deficit without transfers remained at about 1.8 percent of GDP. The central government"s transfers also accounted for the small surplus of decentralized agencies in 1998-99. Excluding these transfers, the operating deficit of decentralized agencies was fairly stable at about 0.8 percent of GDP during 1998-99.

23. The overall balance of public enterprises declined markedly to a deficit of 1 percent of GDP in 1998. This is explained mostly by the privatizations of electricity companies that took place that year, which effectively transferred operating surpluses from the public sector to the private sector while temporarily increasing expenses associated with the preparations for the sale. As these major privatizations were concluded, the balance of public enterprises shifted into a small surplus in 1999, with both revenues and expenditures being significantly reduced.

24. Substantial progress was achieved with public sector structural reform in 1998 and early 1999. The government privatized a sligar mill in addition to the electricity companies, and granted concessions for the operation of the National Casinos and the Trans-Isthmian Railroad. A comprehensive study of the actuarial soundness of the CSS was prepared with the assistance of the International Labor Organization which will serve as input to the ongoing debate on social security reform. The reform of public administration advanced when the government approved a new job classification scheme and implemented new career streams for some occupational groups. Expenditure control has benefited from the

\footnotetext{
${ }^{11}$ Certain central government contributions to the CSS had been withheld due to a disagrement over the amount due.
} 
development and gradual implementation of an electronic and integrated system of financial administration and management (SLAFPA), Changes in the tax legislation eliminated some income tax exemptions to investments in tourism and reforestation, and reduced the amount deductible for mortgage interest payments. The pace of reform slowed considerably in 1999 , with important advances being limited to the expansion of SIAFPA and the start-up of SIACAP.

\section{Developments in 2000}

25. The public sector borrowing requirement during the first nine months of 2000 was contained to US\$86 million (approximately 1.1 percent of the estimated GDP), against US $\$ 302$ million observed in the same period of 1999 . Most of the deficit reduction can be attributed to lower capital expenditures, which declined by US $\$ 202$ million in the comparison between both periods.

26. The central government deficit of US\$294 million in the first nine months of 2000 was about US $\$ 100$ million lower than in the same period of 1999 , mainly because of lower capital expenditures. Both current expenditures and current revenues increased marginally. Nontax revenues - and notably revenues associated with the Panama Canal-continued to grow strongly. Import and sales tax collection declined, however, reflecting the slowdown in economic activity.

27. The operating balance of the CSS remained roughly unchanged from 1999 , although higher transfers from the central government increased the overall surplus. Public enterprises posted a lower operating current surplus that was more than compensated by lower capital expenses, thus closing the first nine months of 2000 with a slightly lower overall deficit than that observed in the same period of 1999 . The surplus of decentralized agencies was reduced to about US\$15 million (about US\$27 million in 1999), reflecting a reduction tin current and capital revenues that offset a decline in current expenditures

\section{The Financial Sector}

\section{Overview and structure}

28. The financial sector of Panama consists of the banking system, the stock exchange, insurance and reinsurance companies, finance houses, and leasing companies. The banking system is by far the most important component. The creation of the Banking Superintendency in 1998 marked the start of a major effort to reform the regulatory and supervisory framework of the banking system (see Chapter III).

29. At end-September 2000 , the banking system consisted of 80 banks, including two publiclyrowned banks: the National Bank of Panama (BNP), and the Savings Bank (Caja de 
Ahorros). ${ }^{12}$ Of these banks, 54 were general license banks, and 26 international license barks. The discussion of commercial banking that follows covers the operations of the general license banks, which are allowed to conduct banking with both residents and nonresidents. International license banks can conduct business only with nonresidents.

30. Finance houses specialize in small business and consumer loans at the lower end of the financial market. ${ }^{13}$ At end-September 2000 , there were 152 such institutions with assets of approximately US $\$ 900$ million. Finance houses are not authorized to accept deposits. Instead, their funding comes from bank loans or through equity participation. Several of the larger finance houses are direct subsidiarjes of banks or members of large commercial conglomerates. In recent years some finance houses have issued various forms of financial paper to the private sector. These unorthodox operations have raised concerns that they circumvent the law prohibiting the finance companies from funding their operations through deposit taking activities. New regulatory legislation for the finance houses is now being prepared.

\section{Commercial banks}

31. Since 1996 both bank liabilities to the private sector and net domestic credit have been growing faster than GDP, with liabilities growing faster than net credit in 1996-97. Since 1997, however, net domestic credit has expanded faster than bank liabilities to the private sector. As a result, net foreign assets of the banking system declined by US $\$ 1.5$ billion between 1997 and 1999. This fall in net foreign assets reflected strong credit demands by the private sector. In 2000 , net foreign assets continued to fall but at a less rapid pace, and although gross foreign assets have increased through September 2000 in part reflecting some recovery in growth in the ZLC--foreign liabilities have grown even faster. ${ }^{14}$

32. Credit to the domestic private sector grew by around 13 percent in 1997. Its rate of growth increased to 22 percent in 1998 before declining to 17 percent in $1999 .{ }^{15}$ The major

${ }^{12}$ Apart from its role as a commercial bank, the BNP functions as the financial agent for the Central Government and the official clearing house for the banking system. It also ensures an adequate supply of U.S. currency to the banking system, and has acted at times to supply liquidity to banks that were short of it.

${ }^{13}$ Traditionally finance houses have catered to the market for small business and domestic consumers who do not meet the credit standards of commercial banks.

${ }^{14} \mathrm{Many}$ of the foreign based companies in the ZLC borrow from Panamanian banks to finance working capital. In 1998-99 ZLC inventories were higher than desired due to weak demand conditions in several major export markets.

${ }^{15}$ Refers to a 12-month change in relation to liabilities to the private sector at the beginning of the period. 
factors affecting this growth in credit was the robust economic activity at first associated with rapid expansion in the ZLC in 1997-98, followed by substantial increases in gross fixed capital formation in 1998-99. At the same time, the sale of properties in the reverted areas stimulated the mortgage loan market, and aggressive competition in the consumer loan market led to rapid growth in that market. As a result, gross credit for personal consumption and mortgages grew by 40 percent and 18 percent respectively, in 1998, and by 9 percent and 36 percent, respectively in $19999^{16}$ The decline in credit demand from the ZLC in 1999 further strengthened the willingness of barks to expand into the area of domestic installment credit. ${ }^{17}$ The growth in credit from the commercial banks to finance houses of 90 percent in 1998 and 38 percent in 1999 implies that finance houses also contributed to the strong growth in credit to the private sector. ${ }^{18}$

33. Competitive pressures also affected the market for credit. Several foreign-owned general license banks attempted to exploit the credit card and lease financing markets, which they viewed as underdeveloped. Domestic banks attempted to match the competition by lowering the minimum income for obtaining a credit card, expanding credit limits and lengthening the repayment period. Banks also reduced the level of their minimum loan requirements and lengthened repayment periods on both commercial loans and mortgages. Although credit growth continued to be strong in 2000, with net credit growing by 15 percent for the 12-month period ending September 2000, the rate of increase has begun to decline.

34. This slowdown reflects several factors. The first is the drop in economic growth and employment. In response, banks have begun to shift, once again, towards the more conservative lending practices of earlier years. Minimum loan amounts have been raised and repayment periods shortened. Moreover, recent large scale repossession of cars has discouraged banks and finance houses from offering lease type arrangements. In addition, the rapid and aggressive market penetration by banks over the last two years was reducing the pool of untapped creditworthy borrowers. As a consequence, gross credit for personal

${ }^{16}$ The increase in gross credit refers to the increase in the stock of credit relative to the beginning-period stock of credit.

${ }^{17}$ Installment credit in Panama is highly collateralized. Individuals must meet specific income standards, each loan must have a guarantor, each borrower must assign to the lending agency an irrevocable right to be repaid through automatic payroll deductions, with this right being transferable whenever there is a change in employment. All consumer loans are insured and the legal framework to enforce compliance with respects to guarantors and to seize and sell assets, of those in default, is strong and functional.

${ }^{18}$ The 90 percent growth in credit refers to growth in the category identified in the accounts of the Superintendency of Banks (SB) as Financial and Insurance Enterprises. The Superindendency reports that $70-80$ percent of the activity in this group is attributable to finance houses. 
consumption and to finance and insurance companies which both grew by around 40 percent by September 1999, on a 12-month basis; had declined to rates of 24 percent and 3 percent respectively, by September 2000. Growth in mortgages, however, continued to be strong growing by 16 percent by end September 2000 compared to 13 percent by end-September 1999. Notwithstanding the rapid growth in credit and the less conservative lending practices of the last two years, the total of loans in arrears and loans written off, as a percent of total loans outstanding, grew from around 2 percent at end-1998 to around 3.2 percent by endSeptember 2000 .

35. Net credit to the public sector in 1998-00 was negative. The CSS has a financial surplus, part of which is invested with the banking system, while the central government has tended to finance much of its deficit through the issue of external debt.

36. Commercial interest rates in Panama following U.S. commercial rates, began to decline in 1997 falling from an average of 10.2 percent for the year to around 9.9 percent in 1998 and have remained relatively unchanged since. At that time the difference between the U.S. prime and Panama's interest rate on commercial loans, which is normally between 200 and 160 basis points, stood at around 200 basis points. During 2000 however, the U.S. prime rate was adjusted upward several times during the year, and the differential between the two rates narrowed to around 40 basis points by September 2000 . Average deposit rates have also remained relatively stable between September 1997 , when the six-month deposit rate stood at 6.2 percent and September 2000 when the same rate stood at 6.4 percent.

\section{The development banks}

37. As noted above, the National Mortgage Bank (BHN) has a mandate to provide housing loans to persons of below-average income. The BHN also provides apartments for rent and sells developed sites, for the purposes of home construction, to persons in this income bracket. The BHN has always run small surpluses on its current operations but these have not been large enough to cover its sporadic, but costly, capital programs. Central government transfers has financed the shortfall. After declining to around US\$3.2 million in 1997, operating profits grew to US\$7.8 million and US\$8.4 million in 1998 and 1999 respectively. The increased surplus in 1998 resulted in part from a strong effort to contain operating expenditure, in part through reductions in staff. In 1999 most of the improved financial performance was due to the sale of houses, and apartments. The BHN has been generally considered to be inefficiently run. In 1996 arrears on loans stood at approximately 24 percent of the loan portfolio. An effort was made in 1997 to forgive interest arrears and the stock of arrears fell to 4 percent of outstanding loans. Since then the arrears portfolio has more than doubled and by end 1999 , stood at around 12 percent of total loans. As of end2000 , the government is planning to submit legislation to the assembly to close the BHN and introduce a more transparent budgetary subsidy to assist the less well off in acquiring a home.

38. The BDA is, like the BHN, generally considered to be inefficiently run. Efforts to reform the bank in the past have floundered over the sensitive political issue of how to 
subsidize the agricultural sector most efficiently given strong resistance to change from sectoral interests. After averaging operating losses of 0.4 percent of GDP in 1996-97 the operating losses of the BDA fell to around less than 0.1 percent of GDP in 1998-99, reflecting measures taken to contain operating costs and improve collections. The operating losses are covered by transfers from the Special Fund for the Compensation of Interest, (FECI). ${ }^{\text {is }}$

39. By the mid-1990s the share of BDA's portfolio in arrears began to grow significantly, and at end 1998 amounted to about 25 percent of the loan portfolio. By September 1999 it had risen to 30 percent, in large part because the bank's new management team decided to apply commercial bank criteria in the classification of the arrears portfolio. In 1998 a new Board was assigned to the BDA, which quickly installed new management and both have been given the task to reform and restructure the BDA. To this end, beginning in November 2000 , an external auditor has begun to review the operations of the BDA. The findings of the auditor will provide the basis for designing a program to restructure the $\mathrm{BDA}$ and to promote the efficient functioning of the bank.

\section{E. External Sector}

40. The external current account deficit widened from about 6.8 percent of GDP in 1997 to 14.4 percent of GDP in 1999 before declining to an estimated 10.4 percent of GDP in 2000. The increase in the deficit between 1997 and 1999 is attributable to an increase in the trade deficit (including the net exports of the ZLC) of 7 percent of GDP and in net factor income payments of 3 percent which offset an increase in the surplus on services and in current transfers. The increase in the trade deficit is largely attributable to a drop in net exports of the ZLC of 3.5 percentage points of GDP, and an increase in consumer and intermediate goods imports of about 3 percent of GDP. In addition, disease and drought reduced shrimp and farm exports in 1999 by about US $\$ 65$ million ( 0.7 percent of GDP). The increase in imports reflects both strong growth in consumer durables and increased demands for intermediate goods used in public works and in construction projects in the newly reverted areas. The increased surplus on services mainly seflected higher transportation revenues (Table 35 ). The increase in net factor payments is largely a consequence of the increase in the deficit in goods and nonfactor services trade.

41. In the first half of 2000 , the current account deficit is estimated to have declined to US $\$ 470$ million from US $\$ 630$ million in the first half of 1999 . The trade deficit also declined by about US\$1 10 million in the same period. Higher exports-including a recovery in reexports of the ZLC-offset the impact of higher oil prices on imports. The service surplus

${ }^{19}$ This Fund is financed by a tax on bank loans. Its proceeds are earmarked as follows: 50 percent of the collections go towards the subsidization of interest on agricultural loans, 25 percent is use for equity support of the BDA, and the remaining 25 percent utilized in the support of cash flow operations. 
also increased by about US $\$ 35$ million, mainly because of higher revenues in travel services (Table 36).

42. Net private sector capital inflows more than fully financed the current account deficits of 1998 and 1999. Foreign private direct investment financed slightly more than 100 percent of the current account deficit in 1998 and about 38 percent of the deficit in 1999.

Acquisitions of privatized enterprises account for much of the FDI in 1998. A reduction in banks' net foreign assets financed about 66 percent of the current account deficit in the latter year. Net external financing of the public sector was negative in both years (Table 35). Although Panama's issued net new external debt of US\$578 million in 1998--99, the impact of debt issue on net external financing was largety offset by an increase in deposits abroad due to the operations of the Trust Fund for Development (TFD). The TFD, which is custodian of the proceeds of privatizations, placed US $\$ 564$ million of these proceeds abroad in cash and near-cash instruments in 1998 and 1999. The overall balance of payments incurred a deficit of US\$193 million in 1998 and US\$91 million in 1999. Net foreign assets of the National Bank of Panama declined by US $\$ 258$ million in the two years. ${ }^{20}$

43. In the first six months of 2000 , private sector net capital inflows more than financed the current account deficit. In particular foreign direct investment financed about two thirds of the current account deficit. Net public sector capital inflows were again negative. The overall balance of payments recorded a surplus of US $\$ 8$ million and the net foreign assets of the Nationai Bank of Panama tose by about US\$6 million (Table 36)

44. External debt management in the last tew years has had two principle objectives: to finance the central government's deficit and to reduce the nominal value of public external debt and the present discounted value of future debt servicing through repurchase operations. In 1998 , the government issued US $\$ 300$ million in ten-year U.S. dollar bonds and repurchased US\$ 43.9 million of Brady bonds issued in 1996, with a face value of US\$70 million. In 1999, the government issued US $\$ 500$ million in 30-year U.S. bonds and repurchased the equivalent of US\$163 miliion of Brady bonds with a nominal value of US $\$ 203$ million. The government then used the released collateral (US $\$ 20.9$ million) from the latter operations to repurchase US $\$ 20$ million of Brady bonds with a face value of US\$27.5 million in the first half of 2000 . Finally, the authorities issued US\$350 million in ten-year U.S. dollar bonds and repurchased the equivalent of US\$99.5 million of Brady bonds with a face value of US\$127 million in July 2000 . While these transactions also led to

${ }^{20}$ The overall balance of payments is defined as the sum of the change in NFA of the BNP, the change in Panama's position with the IMF, and exceptional financing. Panama has no central bank as such. The National Bank of Panama is a publicly-owned commercial bank, and its net foreign assets are not reserves in the conventional sense, since they are not maintained to influence the value of Panama's currency or the operations of the foreign exchange market. 
small reductions in the present value of the external debt, they increased debt service in 1999-00 by increasing amortization payments.

45. Despite these repurchase operations and because of net borrowing from the (InterAmerican Development Bank (IDB), the World Bank and CAF ("Corporación Andina de Fomento"), the stock of the external debt increased by US\$552 million from 1997 to 1999 and by a further US\$175 million in the first nine months of 2000 . In Jelation to GDP, the external debt of the overall public sector remained at about 59 percent in 1997-00, after falling from 63 percent in 1996 and 76 percent in 1995 (Table 48).

46. The nominal effective exchange rate appreciated by about 15 percent during 1999 and the first nine months of 2000 , mainly as a result of the appreciation of the U.S. dollar (Panama's currency) against the other major currencies. However, the real effective exchange rate only appreciated by about $4 \frac{1}{2}$ percent in the same period reflecting Panama's relatively low inflation.

47. In 1995-98, trade and tariff reforms substantially liberalized Panama's trade regime. In particular, a 1997 agreement with the World Trade Organization (WTO) established a maximum import tariff of 40 percent for all but a small number of "sensitive" products" and eliminated nontariff barriers. 22 The agreement also provided for the elimination of both the remaining export tax on bananas by January 1, 1999 and the phase-out of tax credit certificates granted to nontraditional exports by December 31, 2002.

48. Effective January 1, 1998, the government announced further tariff reductions that lowered the maximum import tariff to 15 percent, except for automobiles ( 20 percent), lactose products ( 40 percent), and rice ( 50 percent). However, in October 1999 and in January 2000, the Moscoso administration reimposed the maximum limits agreed with WTO on a small number of the sensitive products. ${ }^{23}$ Until end-2004 these tariffs are to be reduced according to the schedule agreed with the WTO implying a very gradual adjustment. At end2004 they are to be reduced to a maximum of 15 percent.

21 Agricultural products and foodstuffs.

22 The agreement required that procedures for the issue and registration of sanitary permits follow WTO rules by end-1998.

${ }^{23}$ Maximum tariffs for 2000 in the schedule agreed with WTO for these products are the following: boneless and whole hams ( 83 percent), cabbage, carrots, celery, and lettuce (32.5 percent), kitchen oils made from corn or sunflower ( 30 percent) and from soy (20 percent), margarines (20 percent), milk ( 167 percent), onions ( 73 percent), poultry meat in pieces ( 300 percent), rice ( 103 percent), salt ( 87 percent), and tomato paste ( 83 percent). 


\section{The Panama Canal And The Reverted areas-An Update}

1. The Panama Canal Treaty of 1977 , which became effective October 1, 1979 awarded Panama general territorial jurisdiction over the Canal and the lands adjacent to the Canal (formerly known as the Canal Zone, and now known as the reverted areas). The two governments agreed on a gradual transfer of land and facilities during the following two decades. Most of the reverted areas and their properties were in fact transferred in the late 1990s. This chapter describes the institutional arrangements that have been put in place to manage the Canal since the reversion, and summarizes some basic features of its operation and finances. It then turns to describe the management of the integration of the reverted areas into the Panamanian economy and to discuss in general terms the implications of the reversion for the economy of Panama.

\section{A. The Canal}

2. The Panama Canal Treaty dissolved the Canal Zone Government and replaced the Panama Canal Company by the binational Panama Canal Commission (PCC). The PCC was responsible for management, operation, and maintenance of the Canal until the expiration of the treaty on December 31, 1999 when it was replaced by the Panama Canal Authority (PCA). The PCA is an autonomous state entity run by an eleven-member board. Only a minority of board members can be nominated during the five-year term of the President of Panama and the chairperson of the board has cabinet rank in the government. The PCA, unlike the PCC seeks to make a profit on its operations.

3. The Canal, which was inaugurated on August 15, 1914 runs approximately 51 miles from the Caribbean to the Pacific Ocean. The average ship takes 8 to 10 hours to transit the Canal and is raised and then lowered 85 feet by a system of three sets of locks at either end of the Canal. The Canal operates 24 hours per day year round. Each opening and closing of a set of locks uses some 52 million gallons of water. The natural watershed on which the Canal depends faces potential environmental risks due to the changing agricultural patterns in Panama. During periods of drought, the Canal operators are required to conserve water. In extreme periods of drought, like the one in 1998 caused by El Niño, the maximum craught of ships and their transit speed must be reduced to limit ship depth. The restrictions imposed during the recent drought did not reduce noticeably the number of ships traversing the Canal. Nonetheless, the ecological health of the Canal basin has an obvious bearing on the contribution of the Canal to Panama's economy.

4. Canal tolls are based on net tonnage or displacement tonnage if net tonnage is not available. Toll revenue reached US\$569 million (roughly 6 percent of GDP) in fiscal year 1999. The sustained economic growth of the United States, a continuing recovery of Asian economies, and continued low commodity prices all increased demand for cargo transit in 
1999. The Canal by its nature is not a growth industry-there are physical limits to the number and the size of the ships that can traverse it in a year. At the same time, it is not prone to large swings in activity or revenue.

5. The investment program of the PCA for 1995-02 amounts to approximately US\$870 million. Much of the investment budget will be devoted to widening the Gaillard Cut, a section of the Canal whose narrowness prevents two-way traffic. The Canal is currently able to accommodate 35 to 37 vessels a day and has been operating at capacity during the past three years. The widening of the Gaillard Cut, to be completed by end-2002 will increase the average number of daily transits to about 42 vessels per day, a capacity increase of about 15-20 percent. Investments will also be made in the replacement and modernization of Canal equipment (tugboats, towing locomotives, locks machinery, and control systems).

6. The PCA is analyzing the feasibility of building a new set of locks parallel to the existing set to accommodate Post-Panamax vesseis. In contrast to the less ambitious project of widening the existing locks, parallel locks would allow the Canal to remain in operation during construction. They would also require less water, since the wider locks would only be used for Post-Panamax vessels. The project is provisionaily estimated to take 12 years and to cost US $\$ 7.5$ billion, or about 75 percent of GDP in 2000. The PCA bas commissioned a study of its potential profitability. A project of this size would have significant ramifications for both the finances of the PCA and the general economy.

7. In recent years, the relative importance of the Canal in the economy as a whole has fallen due to the emergence of telecommunications and other transportation and transshipment activities. From 1991-99, the value added generated by the Canal's operation averaged 6.4 percent of GDP. During the period 1980-90, the activities of the Canal accounted for a slightly higher annual average of 7.0 percent of GDP. For the first time since 1987, activities in transportation and communication have accounted for a higher percentage of GDP than the activities directly related to the Canal's operation. In 1998-99, transportation and communication accounted for 7.3 percent of GDP while the operations of the PCC accounted for 6.4 percent. This trend is expected to continue given the strong rate of growth in transportation and communication, which has averaged 16.5 percent annually during 1997-99, as Panama fully develops the interoceanic region.

${ }^{1}$ The most recent toll increase of 7.5 percent became effective on January 1, 1998. In 1999 , the average net tonnage per oceangoing commercial vessel increased 1.6 percent to 17 percent, 419 tons. There were 13,136 oceangoing transits in fiscal year 1999,85 percent of which were commercially related-an increase of 0.9 percent over fiscal year 1998 . 


\section{B. Development Strategy and Economic Impact of the Reverted Areas}

8. The process of transferring the former Canal Zone and its infrastructure began in 1979 , but intensified in 1997-99. The interoceanic region that reverted to Panama at the end of 1999 stretches from the Caribbean to the Pacific Ocean on both sides of the Panama Canal. Five army installations, two air force bases, and one naval station were located in the reverted areas. The reverted areas contain many houses, residential areas, schools, hospitals, industrial areas, storage facilities, ports, marinas, golf courses, theaters, bowling alleys, and other recreational facilities. In all, 95,000 hectares and 7,000 buildings and instatlations were transferred. In 1993, the authorities decided to privatize all reverting properties by means of outright sales, or concessions and rentals of the properties.

9. The reversion of the interoceanic region can be expected to increase economic growth. Economic theory suggests that economic growth depends on increases in one or more of the factors of production; land, capital, labor, or technology. The reversion should increase the rate of growth of Panama's economy temporarily if not permanently, because it entails a substantial transfer of land and physical capital. ${ }^{2}$ It creates opportunities for investments that can profitably exploit Panama's comparative advantage in services like transshipment, telecommunications, and other associated Canal activities with high marginal productivities. ${ }^{3}$ These opportunities did not exist previously because the reverted land could not be devoted to commercial or industrial activities-for example, the expansion of ports and the ZLC into adjacent land previously part of the U.S. military bases. In addition, the residential housing in the reverted areas requires little additional expenditure to make it useable.

10. The Interoceanic Region Authority (ARI) is an autonomous government agency created in Febnary 1993 to integrate the reverted areas into the Panamanian economy. ARI is responsible for administering the privatization and use of the reverted areas, and promotes

\footnotetext{
2 Neoclassical growth theory (with exogenously determined technical progress) implies that a once-off increase in the capital stock will not increase the steady-state rate of growth. However, it will increase the rate of growth temporarily, and conceivably for some time, during the transition to the higher steady state. The reverted areas (the former Canal Zone) were not part of Panamanian ternitory, and economic activity there was not included in GDP.

${ }^{3}$ A substantial share of the value added generated by the Canal was already accruing to residents in the form of wages and salaries and payments to the government. Consequently, the transfer of ownership of the Canal itself-apart from the reverted areas-does not greatly increase the nation's capital stock. Assuming unchanged revenues in real terms and a discount rate of 7 percent, the staff estimate that the present value of the additional income stream that accrues to residents of Panama (the government in this case) would be approximately US\$300 million.
} 
investment in ports, industry, commerce, and tourism. The National Maritime Authority (AMN) coordinates the port projects. ARI (in cooperation with AMN) seeks projects that make a contribution to the Panamanian economy by generating local employment, stimulating exports, and using local materiais and inputs when possible. It also requires that investors comply with requirements for the protection of the Panama Canal watershed.

11. ARI receives most of its revenue from the sale of land, housing, and office buildings, but also receives revenue from leasing operations and concessions. ARI's proceeds during 1999 and 2000 from the sale of land, housing, and offices amounted to approximately US $\$ 120$ million.

\section{The development strategy}

12. ARI is promoting investment projects for the reverted areas in maritime facilities and services, other transportation, manufacturing and expont industries, education, and tourism. ARI estimates that to date, approximately US $\$ 1.8$ billion has been invested or committed through 2005 in the interoceanic region. The investment program in maritime facilities and other transportation is particularly significant.

\section{Maritime facilities and services}

13. The maritime sector has already developed considerably, and Panama's two major ports have been privatized and modernized. The large number of ships passing through the Canal and the 22 to 24 hours they spend waiting to enter the Canal creates a natural demand for maritime services. In consequence, new enterprises are being established in ship handling, salvage operations, and maritime insurance. Maritime services to be developed further include ship registration, legal and arbitration services, financial and banking services and naval mortgages, and conmunications and other business-related infrastucture. Specific ship services offered will include hull and tank cleaning, ship and container repairs, crew services, insurance, rescue and towage, brokerage of cargo space, piloting in port, and medical services.

14. The Cristobal and Balboa ports on the Caribbean and Pacific ends of the Canal were privatized in 1997-98, and in 1999-00 an estimated US\$143.6 million was invested in their development. The Manzanillo International Terminal (MIT), located on the Caribbean end of the Canal, transports 70,000 TEUs (20 foot container units) per month. Its operative standard is 30 containers per hour, matching the port movement in Miami. MT has invested US $\$ 12.5$ million to add an additional 20 hectares of operating space to the 37 currently in usage. Adjacent to the MIT, the recently completed Colon Container Terminal, operated by Evergreen, has an operative standard of 34 containers per hour and storage capabilities for 400,000 containers. On the Pacific end of the Canal, the Panama Ports Company, which is a subsidiary of Hutchinson-Whampoa, plans to invest US\$209.2 million in 1999-01 (US\$73.2 million was invested in 1999-..00) to develop the port at Balboa. The Balboa terminal is divided into three phases, with Phase I having been recently completed. Phases I and II will have an estimated annual capacity of 600,000 containers and Phase III will add 
capacity for an additiona] 300,000 containers. The completion of the Balboa port will require deepening the entrance in order to allow large Post-Panamax ships to enter and unload. ${ }^{4}$

\section{Other transportation investment}

15. The Panama Canal Railway Company, a subsidiary of Kansas City Southern Railway, is investing U\$\$75 million to develop a railway that will nun 47 miles and connect the Colon Free Zone and the ports on the Caribbean to the ports on the Pacific. The railway is expected to begin operations in the first half of 2001 . Initially, it will handle only containers. It is expected to add passenger transportation in the medium-term.

16. The railway is part of a proposed multimodal transportation system. The strategy behind the system is to offer a diverse set of transportation modes (maritime, air, rail, and motor vehicle) that improve transportation across the lsthmus and in Panama as a whole. The completion of the multimodal transportation system will require additional investment in the modernization of airports and development of the trucking terminal adjacent to the $Z L C$. The former military bases of Albrook and Howard contain airport facilities. The Administration of the ZLC has designated 23 hectares of the newly added tand at the head of the recently expanded highway from Colón to Panama City for the purpose of developing a modem truck transportation terminal.

17. The ZLC, which is currently situated on 400 hectares of land at the entrance to the Canal on the Caribbean, is adding an additional 885 hectares. This expansion will give it ample room to increase the number of its resident companies, which have already increased from 1,469 in 1990 to 1,944 as of September 2000. The ZLC's expansion will also allow for the expansion of the multimodal transportation system.

\section{Projects in other areas}

18. An export processing zone has been established in the former Fort Davis, focusing on manufacturing and assembly. In addition, tertiary educational establishments are being established in the area of the former Fort Clayton. The tourism sector is also a target for development and several international investors have shown interest in eco-tourist resorts and increased cruise ship transit. The country has about 2,000 miles of coastline on two oceans. Major projects are planned or are in partial execution near Fort Amador at the Pacific mouth of the Canal, including the Amador causeway, cruise ship facilities, hotels, and related services,

19. $\mathrm{ARI}^{\dagger}$ s sale, concessions, or rental of property in the reverted areas has contributed to the development in housing, industry, and tourism. In 1999 and 2000 , housing sales started

\footnotetext{
${ }^{4}$ Ships built with the maximum allowable width to pass through the current system of locks on the Canal are defined as "Panamax." Ships that are too wide to pass through the current system of locks are defined as "Post-Panamax."
} 
several months behind schedule, but have been strong, especially in the former base of Clayton which has becone a focus of Panama City expansion. Clayton is made up of over 2,057 acres and has 1,392 housing units and 39,000 square meters of warehouse space. 


\section{IIT. BANKING SECTOR DEVELOPMENTS ${ }^{1}$}

\section{A. Introduction and Background on Recent Events}

1. Panama has a well-developed banking system, comprised of established domestic and foreign banks run by experienced management teams. The use of the U.S. dollar as the official currency has limited transfer risk and kept interest rates stable and relatively low. Market discipline continues to be an important force for transparency and high operating standards, as there is no lender of last resort or deposit insurance. The supervisory and regulatory environment has evolved rapidly following the passage of the 1998 banking law and creation of the Superintendency of Banks (SB). Bank indicators, especially among Panama headquartered banks, continue to show fundamental soundness in capital adequacy and asset quality, as well as ample liquidity and good profitability.

2. The following four sections cover the structure of the banking system and current banking conditions (Section $B$ ), measures introduced to strengthen the supervisory and regulatory infrastructure (Section C), private banking and anti-money laundering measures (Section D), and key articles and regulations (Section E). Section F presents the chapter's conclusion.

\section{B. Structure of the Banking System and Current Banking Conditions}

\section{Structure}

3. As of September 30, 2000, Panama's banking system comprised 80 general and international license banks with assets of US $\$ 38$ billion. (Table 1 provides market share information on Panama's banking system by assets, loans and deposits.) The banking system is largely privately owned, apart from the Banco Nacional de Panama and the Caja de Ahorros, which are government-owned.

4. The banking system plays a major role as financial intermediary for the domestic economy. Only general license banks and the two government-owned banks are authorized to lend to and take deposits from both residents and nonresidents. General license banks may be foreign or locally owned. The major providers of consumer, mortgage and commercial credit to the local market are 10 large general license banks. ${ }^{2}$ Most of them are headquartered in Panama, but they also include the foreign-owned HSBC, Citibank and Banco Bilbao Viscaya

\footnotetext{
${ }^{1}$ Prepared by Michael K. Moore.
}

${ }^{2}$ The ten large banks active in domestic retail banking are Banco Nacional de Panama, Banco General, Banco del Istmo, Primer Banco, Banco Continental, Banco Bilbao Viscaya Argentaria, Citibank, Caja de Ahorros, HSBC, and Global Bank. Excluded are Banco Latinoamericano de Exportaciones, Dredner, Bank of Tokyo Mitsubishi and Sudameris, which though they are large have limited retail banking activities. 
Argentaria. These 10 banks have between 7 and 53 branches and account for about 50 percent of general license bank assets. The two large government-owned banks have traditionally provided short and long term financing for the consumer market and have the most extensive branch networks. 3

Table 1. Panama: Banking System

(In billions of dollars as of September 30, 2000)

\begin{tabular}{|c|c|c|c|c|c|c|c|c|}
\hline $\begin{array}{l}\text { Type of Depository Financial } \\
\text { Institution (DFI) }\end{array}$ & $\begin{array}{l}\text { Number } \\
\text { of DFIs }\end{array}$ & $\begin{array}{l}\text { Percent } \\
\text { of total } \\
\end{array}$ & Assets & $\begin{array}{l}\text { Percent } \\
\text { of total }\end{array}$ & Loans & $\begin{array}{r}\text { Percent } \\
\text { of total } \\
\end{array}$ & Deposits & $\begin{array}{l}\text { Percent } \\
\text { of total }\end{array}$ \\
\hline General license banks & 54 & 61.4 & 31.0 & 81.8 & 18.8 & 86.0 & 21.4 & 78.4 \\
\hline - Panama headquartered banks & 26 & 29.5 & 20.9 & 55.0 & 12.9 & 58.7 & 12.6 & 45.1 \\
\hline - Branches of foreign banks & 18 & 20.5 & 7.3 & 19.3 & 4.0 & 18.4 & 6.5 & 24.0 \\
\hline - Subsidiaries of foreign banks & 10 & 11.4 & 2.9 & 7.5 & 1.9 & 8.8 & 2.3 & 8.3 \\
\hline Intemational license banks & 26 & 29.5 & 6.9 & 18.2 & 3.1 & 14.0 & 5.9 & 21.6 \\
\hline Representative offices & 8 & 9.1 & \multicolumn{2}{|c|}{ N/A } & \multicolumn{2}{|c|}{$\mathrm{N} / \mathrm{A}$} & \multicolumn{2}{|c|}{$N / A$} \\
\hline Total Banking System & 88 & 500.0 & 37.9 & 100.0 & 21.9 & 100.0 & 27.3 & 100.0 \\
\hline
\end{tabular}

Source: Superintendency of Banks.

5. Of the 54 general license banks, 26 are headquartered in Panama, and have total assets of US $\$ 21$ billion (55 percent of the banking system). Families or local economic groups control most of the Panama headquartered banks. There are 28 foreign banks, with assets of US $\$ 10$ billion that hold a general license and operate as either separately capitalized subsidiaries or as branches.

6. Banks with international licenses can participate in the interbank market, but are restricted in their ability to lend or take deposits from residents. Generally, their activities are limited to providing trade finance or private banking to nonresiderts and other services as directed by their head office. The terms of the international license are similar to that provided by most offshore financial centers, with the notable difference that all licensees must have a physical presence with local staff. Consequently, managed banks that operate under the administration of another bank or nonbank institution are not permitted.

${ }^{3}$ The two government-owned banks were created through specific legislation, but are subject to the same regulations and restrictions as general license banks. 
7. Besides general and international license banks, there are eight representative offices of foreign banks, which cannot take deposits. Their activities are restricted to performing liaison functions and marketing.

8. The foreign bank presence is substantial. (See Table 2 for a breakdown of assets, loans and deposits by geographic region, as well as thè ten largest banks from each region.) Banks from Europe and North America play a major role with Panama assets of US\$11.4 billion and represent ( 30.1 percent of the system total), which compares to US\$3.9 billion and 10.3 percent of the system total for banks from Latin America and the Caribbean, which is the next largest region. Banks from Asia and the Middle East hold the smallest share at US $\$ 1.7$ billion or 4.4 percent of system assets.

\section{Performance}

9. Banking conditions are generally sound. Nonperforming loans (NPLs) increased to 2.9 percent of total loans at end-September 2000 from 1.8 percent at end-1998 and 2.4 percent at end-1999, but remain moderately low (Table 3). The provision level for loan losses has stayed relatively constant since 1998 , so that provisioning, which was 76 percent of NPLs at end-1998, declined to 62 percent at end-September 2000. At end-September 2000 the local banks reported NPLs equal to 2.5 percent of loans and provisioning of 81 percent. For the system as a whole, provisioning is expected to increase, partly due to growth in NQL, but also because of a change in the SB's loan classification and provisioning requirements, which comes into effect in stages starting in January 2001. The regulatory change will reduce income because of higher provision expense, but it is not expected to result in losses.

10. The banking system reported net income of US\$414 million through end-September 2000 or 1.5 percent annualized return on assets, which compares to 1.4 percent earned for all of 1999 (Table 4). Revenue performance for Panama-headquartered banks was better than for the overall system, with an annualized return on assets of 1.9 percent through end-September 2000, up from 1.7 percent for 1999. Through end-September 2000, eight banks reported net losses; all but one was foreign-owned. ${ }^{4}$

\footnotetext{
${ }^{4}$ The Panama headquartered bank reporting a loss began operations in 1998; losses are not uncommon for a newly formed bank. The bank remains very small and its capital remains ample.
} 
Table 2. Panama: Bark Presence by Region

(An billions of dollars as of September 30,2000 )

\begin{tabular}{|c|c|c|c|c|c|c|c|c|}
\hline \multicolumn{9}{|c|}{ Regional aggregates } \\
\hline Geographic Region 1/ & $\begin{array}{l}\text { Number } \\
\text { of DFis }\end{array}$ & $\begin{array}{l}\text { Percent } \\
\text { of total }\end{array}$ & Assets & $\begin{array}{l}\text { Percent } \\
\text { of totat }\end{array}$ & Loans & $\begin{array}{l}\text { Percent } \\
\text { of toma! }\end{array}$ & Deposits & $\begin{array}{l}\text { Percent } \\
\text { of totat }\end{array}$ \\
\hline Panama headquarttied banks & 28 & 35.0 & 20.9 & 55.1 & 12.9 & 58.9 & 12.6 & 46.2 \\
\hline Europe and Norti Antrica & 20 & 25.0 & 11.4 & 30.1 & 5.9 & 27.1 & 10.4 & 38.2 \\
\hline Latin America and Caribben & 26 & 32.5 & 3.9 & 10.3 & 1.8 & 8.3 & 2.7 & 9.8 \\
\hline Asia and Middle East & 6 & 7.5 & 1.7 & 4.4 & 1.3 & 5.7 & 1.6 & 5.8 \\
\hline Total banking system & 80 & 100.0 & 37.9 & 100.0 & 21.9 & 100,0 & 27.3 & 100.0 \\
\hline \multicolumn{9}{|c|}{ Ten largest banks from each region } \\
\hline Panama headquartered banks & & Assets & \multicolumn{5}{|c|}{ Europe and North America } & Assets \\
\hline Banco Latinoamericano de Exportacis & ciones & 5.2 & \multicolumn{5}{|c|}{ Dresdner Bank (Gernany) } & 2.2 \\
\hline Banco Nacional de Paramé & & 3.4 & \multicolumn{5}{|c|}{ HSBC (UK) $2 r$} & 1.0 \\
\hline Banco General, S.A. & & 2.3 & \multicolumn{5}{|c|}{ ABN Amro Bank (Netheriands) } & 0.9 \\
\hline Banco del Istino, SA. & & 1.9 & \multicolumn{5}{|c|}{ Banco Bilbro Viscaya Argent (Spain) } & 0.9 \\
\hline Primer Banco de Alrorros, S.A. & & $1-4$ & \multicolumn{5}{|c|}{ Barique Nationale de Paris (France) } & 0.8 \\
\hline Banco Continental de Paramá, S.A. & & 1.3 & \multicolumn{5}{|c|}{ Citibank, (USA) } & 0.8 \\
\hline Caja de Ahorros & & 0.8 & \multicolumn{5}{|c|}{ Banque Sudameris (italy) } & 0.7 \\
\hline Global Bank Corporation & & 0.5 & \multicolumn{5}{|c|}{ Sociéte Qenerale (France) } & 0.7 \\
\hline Banco Internacional de Panamá & & 0.5 & \multicolumn{5}{|c|}{ HSBC, ple (UK) } & 0.5 \\
\hline Multicredit Bank, Inc. & & 0.5 & \multicolumn{5}{|c|}{ Banco Santarder, S.A. (Spairn) } & 0.4 \\
\hline Ten largest banks from region & & 17.7 & \multicolumn{5}{|c|}{ Ten largest banks from region } & 8.9 \\
\hline 18 other banics & & 3.2 & \multicolumn{5}{|c|}{10 other banks } & 2.6 \\
\hline Total 28 banks for region & & 20.9 & \multicolumn{5}{|c|}{ Total 20 banks for region } & 11.4 \\
\hline Latin America and Caribbean & & Assets & \multicolumn{5}{|c|}{ Asia and Middle East } & Assets \\
\hline Banco Internacional (Costh Rica) & & 0.6 & \multicolumn{5}{|c|}{ Bank of Tokyo Mitsubisht (Japan) } & 0.8 \\
\hline Bancolombia (Colombia) & & 0.4 & \multicolumn{5}{|c|}{ Daj-Ichi Kangyo Bank (Japan) } & 0.3 \\
\hline Banco de la Provincia (Argentina) & & 0.4 & \multirow{2}{*}{\multicolumn{5}{|c|}{$\begin{array}{l}\text { Intemational Conmercial Bank } \\
\text { (Taiwan Province of China) }\end{array}$}} & 0.2 \\
\hline Banco Do Brasil, S.A. (Brazil) & & 0.4 & \multirow{2}{*}{\multicolumn{4}{|c|}{ (Taiwan Province of China) }} & & \\
\hline Popular Bank (Domincan Republic) & & 0.3 & \multicolumn{2}{|c|}{ Korea Exchange Bank (Korea) } & & & & 0.2 \\
\hline Bancafé (Calombia) & & 0.2 & \multicolumn{5}{|c|}{ Bank Leumi-Le Israel, B.M. (1srael) } & 0.1 \\
\hline Banco Santa Cruz (Bolivia) & & 0.2 & \multicolumn{5}{|c|}{ Berk of China (China) } & 0.1 \\
\hline Banco de Oecidente (Colombia) & & 0.2 & \multicolumn{5}{|c|}{-} & - \\
\hline Bancrédito (Domincan Republic) & & 0.2 & \multicolumn{5}{|c|}{ - } & $=$ \\
\hline Banco Unión (Vesezuela) & & 0.2 & \multicolumn{5}{|c|}{-} & - \\
\hline Ten largest banks from region & & 3.0 & & Six ba & ks from $\mathrm{r}$ & egion & & 1.7 \\
\hline 16 other ban ks & & 1.0 & & - & & & & - \\
\hline Total 26 barks for region & & 3.9 & & Total & banks for & region & & 1.7 \\
\hline
\end{tabular}

Souree: Superintendency of Banks.

1/ Includes both general and international license banks (depository financial institutions - DFIs).

2/ Formerly Chase Manhattan Bank (USA). 
Tabte 3, Panama: Trend in Nonperforming Loans

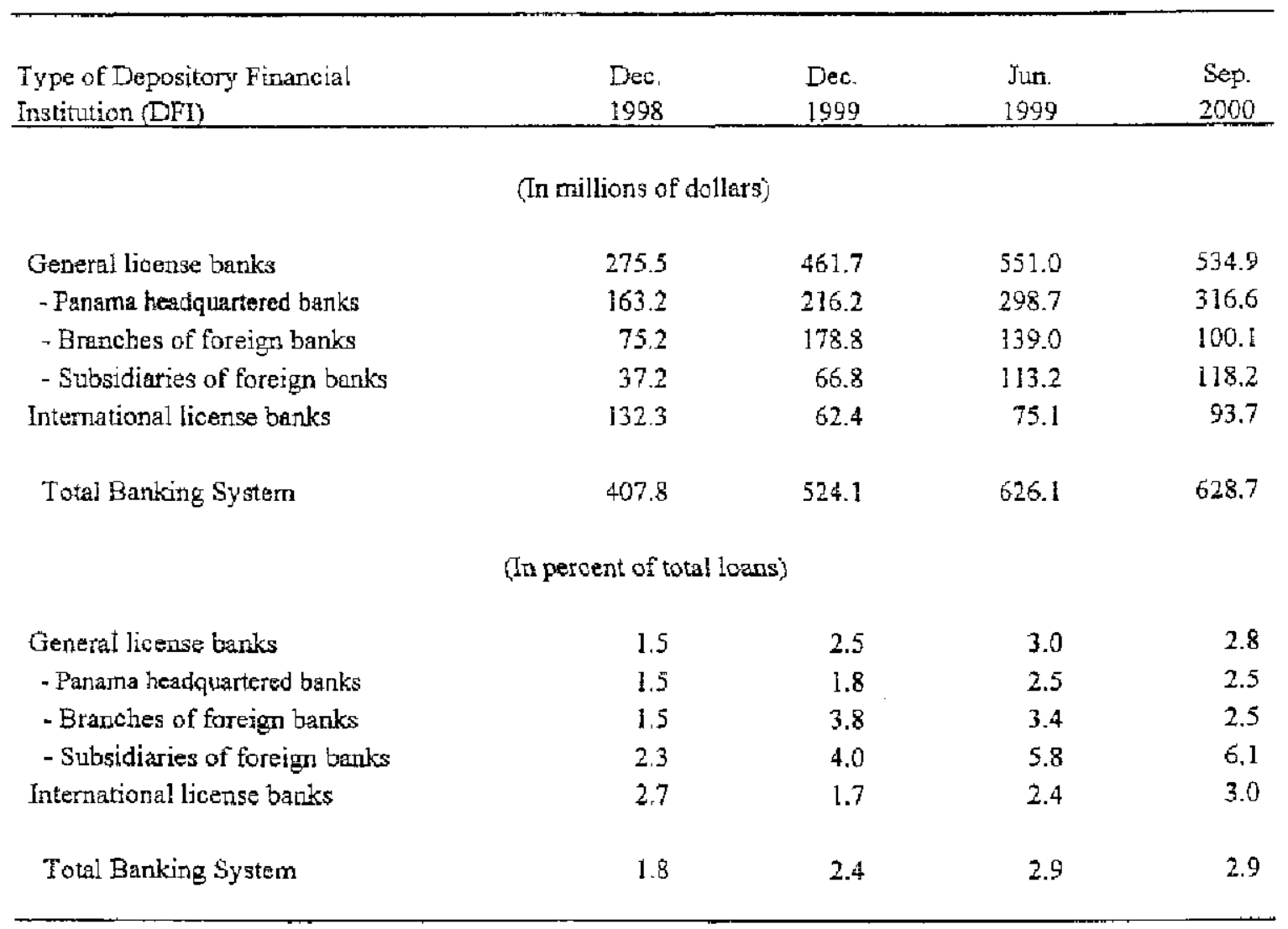

Source: Superintendency of Banks.

11. At end-September 2000, the equity to asset ratio for the system was 9.1 percent, up from 8.6 percent at end 1999. Panama headquartered banks reported an equity to asset ratio of 11.8 percent. The higher figure is partly explained by the fact that the foreign banks mostly operate as branches. A branch of a foreign bank is not required to hold as much capital in Panama as a stand-alone bank or subsidiary because it may rely on the capital position of the foreign head office. The SB requires that banks maintain capital funds of at least 8 percent of risk-weighted assets, including off-balance sheet contingencies.

12. The banking system enjoys stable liquidity provided primarily through deposit funding. Liquid assets are defined to comprise cash, government securities, approved private sector securities, and interbank deposits. (See Section $E$ for a fuller description of liquid assets.) The law requires banks to hold a high level of liquid assets. The minimum ratio of liquid assets to deposits is 30 percent, which must be maintained at all times. Liquidity in the banking system remains stable, as loans represent a conservative 58 percent of assets and 80 percent of deposits at end-September 2000 . The stable liquidity and interest rate environment has allowed many banks to offer long-term, variable-rate mortgages renewable for up to 25 years. Though the deposit base has proved very stable over time, its comparatively short average 
maturity has encouraged banks to match the longer-term lending with more diverse funding provided by long-term, locally raised bonds and term loans from international banksincluding from the International Finance Corporation.

Table 4. Panama: Capital Adequacy and Income Indicators

(In percent)

\begin{tabular}{|c|c|c|c|c|}
\hline \multirow[b]{2}{*}{$\begin{array}{l}\text { Type of Depository Financial } \\
\text { Instiution (DFI) }\end{array}$} & \multicolumn{2}{|c|}{ Equitv to Assets } & \multicolumn{2}{|c|}{ Retum on average assets. } \\
\hline & $\begin{array}{l}\text { Dec. } \\
1999\end{array}$ & $\begin{array}{l}\text { Sep. } \\
2000 \\
\end{array}$ & $\begin{array}{l}\text { Deo. } \\
1999\end{array}$ & $\begin{array}{c}\text { Sep. } \\
20001 \%\end{array}$ \\
\hline General license banks & 9.6 & 10.0 & 1.5 & 1.5 \\
\hline - Panama headquartered banks & 11.3 & 11.8 & 1.7 & 1.9 \\
\hline - Branches of foreign barks & 4.1 & 3.7 & 1.1 & 0.5 \\
\hline - Subsidiaries of foreign banks & 12.1 & 13.0 & 1.0 & 1.9 \\
\hline Intemational license banks & 4.8 & 5.0 & 1.1 & 1.2 \\
\hline Total Banking System & 8.6 & 9.1 & 1.4 & 1.5 \\
\hline
\end{tabular}

Source: Superintendency of Barks.

$1 /$ Return on assets annualized for Sepiember 2000.

\section{Developments in Supervision and Regulation}

\section{History and structure of the Superintendency of Banks}

13. The origins of the passage of the 1998 banking law and the creation of the Superintendency of Banks (SB) lies in the recognition by both bankers and the authorities that the weak supervisory framework then in place was impeding the continued development of the banking system and limiting the opportunities abroad for local banks. Rating agencies and foreign governments were subjecting Panama-headquartered banks to increased scrutiny and introducing obstacles to their establishing a presence in certain foreign jurisdictions. Similarly, internationally active banks faced difficulties in justifying a presence in Panama to both their home country supervisors and their head office.

14. The 1998 banking law established the SB as an autonomous agency. The SB replaced the National Banking Commission, which was relatively weak. The powers of the Superintendency are divided between the Board of Directors and the Superintendent. The board has five members who are appointed by the President of Panama for a maximum of two eight-year terms. They may not serve as officers or directors of any bank, or hold more than 5 percent of the stock of any bank. The Board of Directors is responsible for approving regulations in connection with the interpretation and implementation of banking laws, and 
setting capital adequacy standards. The initial group of board members was appointed with staggered terms ranging from five to eight years so as to not coincide with changes in the executive branch of government.

15. The Superintendent is a salaried, full-time public official who is appointed for a fiveyear term renewable one time. The term of the Superintendent does not coincide with that of the executive branch. The Superintendent's powers include authority: (i) to approve licensing, mergers and consolidations; (ii) to intervene, reorganize and order the compulsory liquidation of banks; (iii) to supervise economic groups; (iv) to order corrective or preventive measures in the operations of banks; ( $v$ ) to establish cooperation with foreign supervisory bodies; and (vi) to set salaries, hire, and fire employees of the SB and oversee the implementation of the annual budget. Neither the directors nor the Superintendent may be removed from office except for specific cause as judged by the Supreme Court of Justice. ${ }^{5}$

\section{Onsite inspections and offsite monitoring}

16. The SB has a professional staff of about 100 for onsite and offsite supervision. In addition, there are 20 staff devoted to the legal and administrative duties for regulations and reviewing applications and another 10 for information systems. In carrying out its onsite inspections, the SB applies the so-called CAMEL criteria, looking at Capital adequacy, Asset quality, Management, Earnings and Liquidity. In its review of management oversight, the SB places considerable emphasis on the intemal control system, including verification of compliance with laws, regulations and banks' own policies. Onsite inspections are not announced in advance. The onsite inspection program is complemented by offsite surveillance by a bank analysis group that looks at monthly prudential indicators and other managerial reports, placing particular emphasis on related party transactions.

17. Through October 2000 , the SB has completed consolidated inspections of 30 general and international license banks and is committed to inspect the remaining banks by end-2001, including the government-owned Banco Nacional de Panamá and Caja de Ahorros. General license and international license banks are subject to the same onsite inspection requirements.

18. To improve both offsite monitoring and system transparency, the SB receives monthly reports from individual banks and publishes an extract of the balance sheet and income information for each quarter on its website. The web-based information is presented both for individual banks and by type of institution, economic sector and region. In adoition, the SB makes available all of its regulations and circulars on the website (several of these are in

\footnotetext{
s The Supreme Court of Justice may order the dismissal of a director or the Superintendent if the person: (i) is permanently incapacitated; (ii) declares bankruptcy; (iii) no longer meets the requirements for appointment; (iv) demonstrates dishonesty in his or her functions; or (v) fails to comply with the obligations and prohibitions imposed under the banking law.
} 
English). The SB is working to enhance further its information system, for example by requiring that banks use the internet for transmitting information to the SB directly. The new system should help to address two weaknesses related to collection of information on riskbased capital requirements and consolidated financial statements for individual banks and their subsidiaries (see Section E). The IDB is financing this effort to improve the overall quality of information on bank operations.

\section{New regulations}

19. In its first 18 months of operation, the SB issued the new regulations dealing with the following activities or areas: (i) accounting and auditing standards, (ii) a Basel-like capital adequacy requirement, (iii) exposure limits on credit to related parties and single obligors (iv) and risk management requirements for liquidity, interest rate and country risk. Most recently, the SB has issued additional regulations for loan classification and provisioning that come into force beginning in 2001, and a know-your-customer regulation that now is in effect. The latter implements a regulation for the banking sector following the passage of anti-money laundering legisiation in October 2000 (see below). These regulations conform to standards of accepted international practice. A summary of individual regulations is provided in Section E.

\section{The view of the Financial Stability Forum}

20. In May 2000, the Financial Stability Forum (FSF) released its groupings of offshore financial centers, which was based on the views of onshore supervisors in 27 countries. The FSF placed Panama along with 26 others in Group III, the lowest ranking group. ${ }^{6}$ Countries in Group III are characterized by the FSF as "generally seen as having a low quality of supervision, and/or being noncooperative with onshore supervisors, and with little or no attempt being made to adhere to international standards."

21. The SB regrets the FSF's characterization, and believes that the FSF has not considered the important advances in Panama's system of regulation and supervision. To counteract the FSF's rating, and to take stock of its progress towards meeting international standards for prudential supervision, the SB completed in October 2000 a self-assessment assisted by a Fund staff member of its compliance with the Basel Core Principles for Effective Banking Supervision (BCP). ${ }^{7}$ In April 2001, at the authorities' request, Fund will conduct an

\footnotetext{
${ }^{6}$ The other two groupings are: Group I-jurisdictions generally viewed as cooperative, with a high quality of supervision, which largely adhere to international standards and Group IIwould be jurisdictions generally seen as having procedures for supervision and cooperation in place, but where actual performance falls below international standards, and there is substantial room for improvement.

${ }^{7}$ The self-assessment of BCP compliance was assisted by the writer.
} 
independent, BCP assessment. Under the Fund's rules, the authorities may choose to publish the results of that assessment.

22. As already noted the SB has achieved important progress in putting in place a proper system of supervision and regulation, conforming to internationally accepted standards. The independent assessment beginning in April will examine the concerns raised by the FSF.

\section{Private Banking and Anti-Money Laundering Measures}

23. Panama is a significant regional center for private banking. ${ }^{8}$ Both local and foreignowned banks offer private banking services primarily to Latin American clients, and compete effectively with onshore centers in North America and Europe. There is a tradition of strong bank secrecy provisions that oblige bankers and bank supervisors to keep bank client information strictly confidential. Improper disclosure of information by bankers or supervisors is punishable by fine or imprisonment.

24. The authorities and the banking industry are very aware of the legal, operational, and reputational risks associated with private banking. Cabinet Decree Law number 41 , issued in 1990 , requires banks and nonbanks to have systems in place to prevent the laundering of proceeds from drug trafficking. In June 2000 the Financial Action Task Force strongly criticized the existing anti-money laundering regime, and listed Panama as "noncooperative" in the fight to combat money laundering. ${ }^{9}$ The FATF cited four principal shortcomings: (i) failure to criminalize money laundering for crimes other than drug trafficking; (ii) inefficient reporting of suspicious transaction reports to competent authorities; (iii) overly restrictive rules for international information exchange; and (iv) civil law provisions that impeded the identification of the true beneficial owners of trusts.

25. To address the FATF's criticisms, the authorities, with the strong support of the banking industry, enacted laws $4 \mathrm{I}$ and 42 in October 2000 . The new laws criminalized the laundering of proceeds from fraud, extortion, embezzlement, corruption of public officials, kidnapping, terrorism and theft or trafficking in vehicles or weapons. In addition, they streamlined the reporting of suspicious transactions to the competent authorities and facilitated the exchange of information with other governments. ${ }^{10}$ Lastly, the laws expanded the SB's ability to examine anti-money laundering compliance by trust companies.

\footnotetext{
${ }^{8}$ Private banking is the providing of financial and related services to wealthy individuals (including their closely held companies).

The Financial Action Task Force is made up of 29 member countries and territories, primarily composed of OECD members; the Secretariat is based at the OECD.

${ }^{10}$ Executive Decree No. 163 authorizes the government to exchange information regarding suspicious activity with counterparts in foreign jurisdictions so long as there is a
} 
26. The SB under Decree Law 41 of 1990 and under the recent legislation has the responsibility to enforce compliance with anti-money laundering laws and regulations in the banking sector. The new legislation gives the SB broad authority to use the means necessary to ensure that banks comply with the law, including the authority to issue regulations intended to deter money laundering. ${ }^{11}$

27. The SB's anti-money laundering program has two primary focuses: (i) know your customer (KYC) compliance and (ii) suspicious activity reporting. Compliance with laws, regulations and banks' own policies is verified through onsite inspections. KYC requirements apply to individuals and corporations, including bearer share companies. Other areas reviewed by the SB are records retention practices, ${ }^{12}$ the adequacy of anti-money laundering training and banks' own internal anti-money laundering policy. The inspection work papers evidenced that the SB's inspectors are reviewing compliance with $\mathrm{KYC}$ and reporting requirements. Instances of noncompliance with Panama's anti-money laundering laws are brought to bank management for prompt correction.

28. Panama is a member of the Caribbean Financial Action Task Force (CFATF) and the Egmont Group. A team from CFATF members has conducted a mutual evaluation of Panama's compliance with the FATF and CFATF anti-money laundering recommendations. ${ }^{13}$ The Egmont Group is an association of "financial intelligence units" (FIU). An FIU is responsible for receiving, analyzing and disseminating financial information concerning suspicious transaction reports.

\section{E. New Regulations}

\section{Capital requirements for general and international license banks}

29. The SB has imposed a risk-based capital framework that is modeled after the original Basle capital standard. The framework is applicable to both general and international license banks. Capital is defined as primary capital plus secondary capital, with primary capital equal to paid-in-common and perpetual preferred shares, declared reserves and retained earnings.

Memorandum of Understanding in place. The authorities are actively seeking an MOU with the United States.

${ }^{11}$ The SB issued Agreement 9-2000 as an implementing regulation for the new law.

${ }^{12}$ By law, banks are required to maintain customer documentation for a minimum of five years. This requirement applies to closed as well as active accounts.

${ }^{13}$ The CFATF is a regional anti-money laundering group modeled after the FATF. Their activities include conducting mutual evaluations of members, training activities and technical assistance programs. 
Secondary capital is comprised of qualifying subordinated debentures, other hybrid capital instruments, and general reserves for loan losses. Together, primary and secondary capital must be at least 8 percent of risk-weighted assets, and secondary capital cannot exceed primary capital. Assets are assigned different risk weights that range from a zero weight to 100 percent weight (e.g., cash has a zero weight and loans have a 100 percent weight). Offbalance sheet items are included as assets according to their cash equivalency. The SB does not impose a capital charge for market risk.

30. In addition to the adoption of the risk-based capital requirement, there is a minimum capital level requirement. General license banks are to maintain a minimum capital level of US $\$ 10$ million and international license banks are to maintain a minimum level of US\$3 million. International license banks must deposit US $\$ 250,000$ in the BNP or invest that amount in bonds held in the custody of the BNP. Those banks not meeting the minimum requirement will have five years from the date of the enactment of the law to reach the required capital level. Those banks not meeting the minimum capital requirement during the five year transition period will not be allowed to pay dividends and may be subject to other sanctions. If after the five years the capital of a bank fails to reach or falls below the minimum level, the bank will not be allowed to continue operations. Branches of foreign banks may have this amount assigned on the books of the head office.

\section{Accounting standards, regulatory reports and transparency}

31. The SB requires that banks and economic groups file financial information using either International Accounting Standards (IAS) as issued by the International Accounting Standards Committee or U.S. General Accepted Accounting Principles (US GAAP) as issued by the Financial Accounting Standards Board. The requirement applies to both the general and international license banks. The change affects the reporting of financial statements and other information filed after the start of calendar year 1999. Because of the relative conservatism of existing accounting practices, meeting the higher standard did not impose a serious difficulty for the banks. Many of Panama's larger domestic-owned financial institutions were already reporting their financial results using US GAAP. Similarly, adoption of the international standard had little effect on the many foreign banks operating in Panama. They were accustomed to the higher standard because it was already in place in their home countries.

32. The SB requires that banks file various types of condition reports on a weekly, monthly, quarterly and annual basis. Failure to comply with reporting requirements can result in a fine imposed by the SB. Efforts are underway by the SB to provide more financial and structural information on individual banks via its website that already includes monthly, unconsolidated bank-by-bank and system financial information. Once a year, the banks are to provide the financial statements on an audited basis. The five major international accounting firms carry out most accounting and external auditing activity.

33. As already mentioned, the $\mathrm{SB}$ is revising its program for collecting prudential information from banks with financial support from the IDB. As the design evolves, it will be 
important that the SB ensures collection of key prudential indicators for offsite monitoring. It is noted that the SB collects risk-based capital information only on an annual basis for which at least a quarterly monitoring capability is warranted. Also, the SB will need to ensure that it collects the routine financial reporting on a consolidated basis at the bank level, consolidating the results of both the bank and its subsidiaries. ${ }^{14}$ The consolidated reporting at the bank level would be in addition to the consolidated reporting that would occur at the corporate level as required by the International Accounting Standards and U.S. GAAP. The purpose of consolidated reporting at the bank level is to have a view of all of the risks faced by the bank, which may be hidden, without the consolidation of the accounts of the subsidiaries.

Consolidated reporting at the bank level will be important to ensuring compliance with limits for loans to related parties and loans to a single borrower.

\section{Consolidated supervision (including cross-border supervision)}

34. The SB is empowered to supervise economic groups and their bank and nonbank affiliates on a consolidated basis. Its powers include the right to require audited financial statements and other reporting information as appropriate from the bank and nonbank affiliates of economic groups. ${ }^{15}$ Still to be inspected are several of the more complex general license banks, which will pose important challenges given the range of financial and nonfinancial activities in which they are involved. Although the development of the system for consolidated supervision is largely complete, some policy work is warranted with regard to the types of specialized financial and nonfinancial activities that should be permitted within a bank or a bank subsidiary. The policy should consider the appropriateness of the activity for a bank or bank subsidiary, its relative size, the demand it makes on management and the degree to which its accounts obscure the transparency of the bank's operations.

35. As an important regional banking center, the SB requires that all offices of foreign banks be subject to consolidated supervision by their home country supervisor. In addition, several Panamanian banks have subsidiaries in neighboring jurisdictions, primarily in Central America and the Caribbean. To facilitate the cross-border supervision, the SB has pursued memorandums of understanding (MOU) with 16 foreign jurisdictions in the Western Hemisphere. Of these, four have been agreed and signed, one is agreed, but awaiting final signature, two have been deferred, and nine others are under active negotiation.

${ }^{14}$ Consolidated financial statements are a combination line-by-line of all like items (assets, liabilities, equity, income, expenses and off-balance sheet items). In conjunction with the combination of like items, intragroup balances and transactions are eliminated.

13 The applicable regulation is Agreement 3-99, Consolidated Supervision of the Economic Banking Group. 
36. The MOUs are intended for the sharing of information for supervisory purposes only, which contrasts with MOUs intended to facilitate information flows for law enforcement or crime prosecution purposes. Though the SB prefers an MOU, it is not a pre-condition to conducting an onsite inspection by a foreign supervisor, which can be arranged on a case-bycase basis. The arrangement will set out guidance on use of information and will stipulate that information obtained be for supervisory purposes only. There is a precedent for allowing an onsite inspection by a foreign supervisor without an MOU being in place. Despite the large number of foreign banks operating in Panama, especially from Europe and North America, the SB reports that it has not received any requests from foreign supervisors to conduct on-site inspections.

\section{Single borrower limit and loans to related parties}

37. The 1998 banking law (Article 63) establishes a 25 percent limit relative to bank capital on the level of lending and other exposure that a bank may have to a single botrower. The limit applies only to general license banks. A single borrower is a natural or legal person or an economic group. The definition of an economic group is a group of natural or legal persons whose interests are so interrelated that in the opinion of the SB they are to be treated as a single person. Agreements 1,7 , and 9 for 1999 provide detailed requirements and restrictions on lending or the purchase of securities issued by a single obligor or a single economic group.

38. The 1998 banking law (Article 64) and regulations issued by the SB have established restrictions on credit exposures to related parties and related economic groups (both through loans and the purchase of securities) ${ }^{16}$ Credit exposure to any one related party is limited to 10 percent of bank capital, if the exposure is secured by real estate and 5 percent of bank capital if unsecured. In addition, there is a global cumulative limit equal to 75 percent of the bank capital that declines to 25 percent by 2005 , with an intermediate limit of 50 percent for 2002. The transition to the cumulative 25 percent limit was needed to allow time for banks to adjust without a serious disruption. These limits once fully in force will be in line with accepted international practice.

\section{Loan classification and provisioning requirement}

39. Under the new loan classification and provisioning regulation that comes into force beginning January 2001, general and international license banks are to classify loans according to five categories as follows: Normal, Special Mention, Subnormal, Doubtful and

\footnotetext{
${ }^{16}$ Applicable regulations are Agreements 2, 8, and 10 for 1999. Related parties are bank directors, individuals owning 5 percent or more of a bank's shares, managers, officers, employees and their spouses and any entity for which the bank or its directors or officers control (individually or jointly) a significant influence.
} 
Unrecoverable. Loan classifications need to consider the bank's lending policies and procedures, the borrower's financial condition and repayment capacity, assessment of cash flow and market value and the potential for realizing the collateral.

40. After the phase in period, banks will be required to maintain provisioning equal to the higher of one percent for the whole loan portfolio or the cumulative provisions required according to the individual loan classification. The amount of provisions for individual loans is to reflect the probability of loss, whereby loans with a classification of Special Mention would require a provision of between two and 14 percent, Subnormal between 15 percent and 49 percent, Doubtful between 50 percent and 99 percent, and for Unrecoverable 100 percent.

41. Under requirements in place through end-2000, loans classified as Doubtful must be provisioned at 50 percent and those classified as Unrecoverable at 100 percent. During the phase-in, one haff of the increase in provisions under the new regulation must be met by endJune, with the full amount of the increase to be met by end 2001. The SB may instruct banks to establish higher provisions than would be called for by the regulation and provisions may be reduced for particular loans depending on quality of collateral.

\section{Liquidity requirements}

42. Minimum liquidity requirements are set by Article 46 to 49 of the 1998 banking law. General license banks must maintain at all times liquid assets equal to at least 30 percent of total deposits. The SB may restrict on a case-by-case basis the share of certain liquid assets in the total qualifying liquidity of a bank. To monitor liquidity, banks must submit weekly liquidity reports. Liquid assets, which must be unencumbered and freely transferable, include the following: (i) gold or currency of legal tender in Panama; (ii) clearing balances due from banks; (iii) demand and time deposits (maturity less than one year) held in Panama banks; and, (iv) treasury bills and other Panamanian governmemt securities with less than one year maturity valued at market value.

43. Liquid assets can include demand and time deposits (maturity less than six months) and other liquid balances held in foreign banks pre-approved by the SB. Also with the approval of the SB, debt instruments of foreign governments, foreign financial institutions and private companies can be allowed The instruments are to be carried at their market value, must be of investment grade and actively traded on well-recognized exchanges.

\section{F. Conclusions}

44. Over several decades, Panama's banking system has evolved into an important regional banking center largely following a model of self-regulation. The banking industry and government came to recognize that self-regulation had its limitations and in tandem worked to adapt an appropriate framework for supervision and regulation to the banking system, which resulted in the passage of the 1998 banking law and the creation of the SB. The SB and its supervisory staff demonstrate a high level of professionalism and integrity and receive high 
marks within the banking industry, having established credibility through the rapid pace of reform designed to introduce a modern supervisory and regulatory framework.

45. Panama confronts a new challenge due to concerns raised by the Financial Action Task Force (FATF) and Financial Stability Forum (FSF). The authorities have moved quickly to pass and implement new laws and regulations to deal with the FATF criticism and demonstrate that Panama is working aggressively to combat money laundering. To address the FSF concern, the authorities are continuing their efforts to modernize the supervisory and regulatory environment that have been underway since 1998 . The SB is participating in the IMF's initiative for offshore financial centers and has agreed to an assessment under Module 2 of the OFC program beginning in April 2001. This assessment will examine the concerns raised by the FSF. 


\section{Poverty In Panama-Findings Of A Recent Assessment}

1. Poverty in Panama remains pervasive in spite of the country's comparatively high income per capita of US\$3,395 in 1999. The Government of Panama, with assistance from the World Bank, recently completed a comprehensive poverty assessment. ${ }^{1}$ This chapter summarizes its major conclusions.

2. About 37 percent of the population, or 1 million people, live below the poverty line and 19 percent of the population, or over half a milion people, live in extreme poverty. ${ }^{2}$ Over 50 percent of children in Panama live below the poverty line. Poverty is concentrated heavily in rural areas and is most highly concentrated within the indigenous population. Although the indigenous population only accounts for one-eighth of the overall population, an estimated 95 percent, about 197,000 people, fall below the poverty line and 86 percent live in extreme poverty. Although not as pervasive as in rural areas, poverty in urban areas is of concern as 15 percent of the urban population falls below the poverty line. Moreover, many city dwellers live just above the poverty line, making them vulnerable to the effects of job loss, illness and other contingencies.

\section{A. Causes of Poverty in Panama}

3. The problems of poverty are the result of the highly unequal distribution of productive assets such as labor, human capital, physical assets, and access to financial markets. Labor is the most abundant asset available to the poor, accounting for 77 percent of total income versus 69 percent for the nonpoor. High rates of unemployment and disparities in educational opportunities often prevent the poor from increasing their skills and knowhow. Unemployment is highest among the urban poor, women, and the young. Many of the employed poor work as day laborers in the informal sector. In all, nearly 80 percent of the extremely poor and 70 percent of the poor work in the informal sector. A majority of poor and extremely poor women are employed in the informal sector.

4. Progress has been made in recent years as regards the educational attainment of all economic groups, but gaps remain in literacy, attainment, and coverage. Literacy rates in Panama are relatively high. About 97 percent of the nonpoor and 83 percent of the poor are literate. Nonetheless, less than two-thirds of those over age nine in the indigenous population can read and write, and rates for women are lower than those for men. Enrollment levels

\footnotetext{
${ }^{1}$ Panama Poverty Assessment: Priorities and Strategies for Poverty Reduction. The World Bank, Washington, D.C., 2000.

${ }^{2}$ Extreme poverty is defined in the Panama Poverty Assessment as the level of per capita annual consumption required to purchase the minimum average daily caloric requirement. The full poverty line includes an allowance for nonfood items. The annual cost of achieving the extreme poverty line was estimated at US\$519 and the full poverty line, US\$905.
} 
continue to be affected by the high direct costs of schooling, which at the primary and secondary level represent 12 percent and 28 percent of income, respectively, of a household at the poverty line. Even if the poor are able to finance the high direct costs of schooling, the quality of education they receive is deficient, given the dearth of bilingual (Spanishindigenous languages) learning materials, schools that are close-by, teachers, and basic textbooks. As a result, educational attainment is lowest among the indigenous poor (average of 3.3 years of schooling), followed by the rural poor ( 5.1 years), and the urban poor ( 7.0 years). In contrast, the nonpoor have average schooling of 9.5 years.

5. The overall level of public expenditure on education appears adequate at 6 percent of GDP, but its distribution is inequitable and regressive. The poor represent 43 percent of the school aged population, but only receive 28 percent of total spending on education. Education spending is split roughly equally among primary, secondary, and tertiary education. Virtually all of the spending on higher education benefits the nonpoor and over 40 percent of higher education subsidies favor the highest income quintile. Education spending is also tilted in favor of the urban areas despite the fact that the poor are located predominantly in rural areas. In total, the urban areas receive 65 percent of education spending even though their inhabitants account for 53 percent of the population ages 5-24. This compares to 30 percent of spending for rural areas and only 5 percent for the indigenous population even though the rural areas account for 38 percent and the indigenous population 10 percent of those in the 5-24 age group.

6. The unequal distribution of physical assets, such as housing and land, prevents the use of property as collateral for credit. Those poor who own land tend not to bave title to their property. The assessment cites the lack of a property title as the principal reason the poor are refused access to credit in the financial system (the size of land holdings and the possession of land titles are the two main factors influencing access to, and volume of, agricultural lending in rural areas). According to the study, 79 percent of poor homeowners and 64 percent of poor land owners lack proper titling. Overall, 50 percent of all homeowners and 51 percent of all land owners lack proper titling. In addition, the study estimates that titling contributes an average of US $\$ 456$ per hectare in land value, suggesting that the market places a high value on the existence of a title.

7. The characteristics of poverty in Panama are reflected in a dual pattern of historical development. Panama's geographical location combined with the existence of the Canal and a monetary arrangement that uses the U.S. dollar as legal tender has fostered the development of an internationally oriented service sector and financial center. This modern service sector operates side by side with traditional agriculture and manufacturing industries that have been constrained until recently by a protectionist trade regime that fostered low productivity. Because of the specialized nature of Panama's service economy, education reform is necessary to bridge the gap for the poor to move into productive, higher wage jobs. The duality of the economy has resulted in large wage differentials between those employed in the service sector and those in the rest of the economy. In addition, this distortion may have increased the rate of unemployment and encouraged the informal labor market by increasing 
the relative price of labor and, therefore, reducing the demand for the poor's most abundant asset.

\section{B. Poverty Reduction Strategy and Reform}

8. Poverty reduction is the top priority of the new government, as emphasized in the Social Agenda. This agenda outlines the principles for reducing poverty, strengthening the key assets of the poor, and assessing the geographic differences in the distribution of poverty. The strategy includes: increased efficiency in social spending to improve human capital, specific targeting of resources to the poor, a program to decentralize services and improve efficiency, increased community participation, and comprehensive monitoring of the available indicators of the incidence of poverty and implementation of programs. The study recommends that the government: prioritize among poverty groups; reallocate existing public expenditures in education, healthcare, and other basic services to target key groups among the poor; implement policy reforms to reduce disparities in assets; and improve targeting mechanisms. The Poverty Assessment estimates the minimum annual cost of eliminating poverty (bringing all poor Panamanians to the poverty line) at approximately 5 percent of GDP and the cost of eliminating extreme poverty at 1 percent of GDP. ${ }^{3}$

9. The main priority should be a reallocation of existing spending as opposed to additional spending. Investing in education is seen as the principal means for alleviating poverty in the long run and gains can be made at reasonable costs. The Poverty Assessment estimates that full enrollment in primary schooling would cost about US\$12 million (0.14 percent of GDP). Full coverage in secondary schooling would cost about US\$89 million ( 1 percent of GDP), but coverage in secondary schooling only for the poor would only amount to three quarters of this amount. ${ }^{4}$ Given that each year of schooling is estimated to add an additional five percent increase in hourly earnings, such investments should be considered.

10. A key recent poverty reform of the Government of Panama has been to expand the coverage of land titling by modernizing land administration services and launching a streamlined national land titling program that includes air photography land studies. In addition to the 690,000 hectares that have been titled from 1963-99, a US\$400 million pilot program, funded by the Government of Panama and the IDB, has been initiated in the province of Veraguas to title over 500,000 hectares. The second phase of this program is to be implemented in the provinces of Herrera and Los Santos and title an estimated 620,000 hectares. Approximately 6,000 titles were granted in September and October of 1999. It is estimated that this expanded program will issue over 60,000 new land titles by

${ }^{3}$ These estimates take account only of the direct cost of poverty alleviation. They do not, for example, take account of administrative costs.

${ }^{4}$ These assessments do not take account of the leakage that would result from less than perfect targeting. 
2004. However, while ambitious, this program only targets land owners in general, not poor land owners. The poor account for approximately two-thirds of the rural population, but only own one-third of agricultural land. Half the poor in the rural areas are landless and, consequently, will not benefit from a titling program. This underscores the importance of taking other measures, and in particular improving the targeting of social expenditure, especially health and education. 
Table 5. Panama: National Accounts by Productive Activity

\begin{tabular}{|c|c|c|c|c|c|}
\hline & 1995 & 1996 & 1997 & 1998 & 1999 \\
\hline \multicolumn{6}{|c|}{ (In millions of balboas at 1982 prices) } \\
\hline Gross donvitic prodact at market prices & $6,198.0$ & $6,372,2$ & $6,657.4$ & $6,947.2$ & $7,152.2$ \\
\hline Primary activity & 517.8 & 522.2 & 528.5 & 564.2 & 5626 \\
\hline Agrioulture & 509.2 & 515.0 & $\$ 14.9$ & 547.5 & 545.4 \\
\hline Mining & 8.6 & 7.2 & 13.6 & 16.7 & 17.2 \\
\hline Stcondary activity & 874.6 & 856.2 & 908.6 & 951.5 & 956.8 \\
\hline Manufactoring & 615.8 & 608.1 & 646.8 & 672.1 & 632.8 \\
\hline Construction & 258.8 & 248.1 & 261.8 & 279.4 & 324.0 \\
\hline Servicess & $4,784.2$ & $4,984.2$ & $5,225.9$ & $5,473.8$ & $5,733.1$ \\
\hline Public utilifies & 259.9 & 305.9 & 308.2 & 294.0 & 348.9 \\
\hline Commete, restattants, and hotels & $1,280.4$ & $1,267.8$ & $1,381.2$ & $1,411.1$ & $1,371.7$ \\
\hline Colon Free Zone wholesale & 516.6 & 490.2 & 570.7 & 554.1 & 473.8 \\
\hline Restaurants and hotels & 95.0 & 100.9 & 107.7 & 113.3 & 117.8 \\
\hline Other & 668.8 & 676.7 & 702.8 & 743.7 & 780.1 \\
\hline Transport and communications & 761.3 & 780.1 & 8249 & 914.7 & $1,006.2$ \\
\hline Panama Canal Conmission & 419.4 & 429.9 & 423.6 & 442.7 & 452.3 \\
\hline Other transport and comm. & 341.9 & 350.2 & 401.3 & 472.0 & 553.9 \\
\hline Financial intennediation & 641.8 & 725.4 & 729.2 & 809.4 & 887.1 \\
\hline Housing & 841.4 & 879.2 & 908.8 & 937.2 & 981.6 \\
\hline Public adrministration & 653.5 & 665.3 & 690.6 & 711.3 & 721.3 \\
\hline Other aervices & 345.9 & 360.5 & 383,0 & 396.1 & 416.3 \\
\hline Plus: import taxes $2 /$ & 249.8 & 256.5 & 270.4 & 294.4 & 292.8 \\
\hline Less: imputed banking æervices & 228.4 & 246.9 & 276.0 & 336.7 & 393.1 \\
\hline \multicolumn{6}{|c|}{ (Percent change) } \\
\hline Gross domestle product at 1982 marlet prices & 1.8 & 2.8 & 4.5 & 4.4 & 3.0 \\
\hline Primary activity & 3.1 & 0.8 & 1.2 & 6.8 & -0.3 \\
\hline Agriculture & 3.2 & 1.1 & 0.0 & 6.3 & -0.4 \\
\hline Mining & -5.5 & -16.3 & 88.9 & 22.8 & 3.0 \\
\hline Socandary activity & 1.3 & -2.1 & 6.1 & 4.7 & 0.6 \\
\hline Manuffachoring & 0.2 & -1.3 & 6.4 & 3.9 & -5.8 \\
\hline Construction & 4.1 & -4.1 & 5.5 & 6.7 & 16.0 \\
\hline Services & 1.6 & 4.2 & 4.8 & 4.7 & 4.7 \\
\hline Publis utilities. & 1.9 & 17.7 & 0.8 & -4.6 & 18.7 \\
\hline Commerce, restaurants, and hotels & .0 .7 & -1.0 & 8.9 & 2.2 & -2.8 \\
\hline Colon Free Zone tholesale & -3.2 & -5.1 & 16.4 & -2.9 & -1.4 .5 \\
\hline Restauranks and hotels & 5.2 & 6.2 & 6.7 & 5.2 & 4.0 \\
\hline Other & 0.4 & 1.3 & 3.9 & 5.8 & 4.9 \\
\hline Transport and communications & 9.4 & 2.5 & 5.7 & 10.9 & 10.0 \\
\hline Panama Cansal Commission & 15.7 & 2.3 & -1.5 & 4.5 & 2.2 \\
\hline Other trassport and comm. & 2.5 & 2.4 & 14.6 & 17.6 & 17.4 \\
\hline
\end{tabular}


Table 5. Panama: National Accounts by Productive Activity (Concluded)

\begin{tabular}{|c|c|c|c|c|c|}
\hline & 1995 & 1996 & 1997 & 1998 & 1999 \\
\hline Financial intermediation & -4.9 & 13.0 & 0.5 & 11.0 & 9.6 \\
\hline Housing & 2.5 & 4.5 & 3.4 & 3.1 & 4.7 \\
\hline Public administration & 3.4 & 1.8 & 3.8 & 3.0 & 3.4 \\
\hline Other services & 1.3 & 4.2 & 6.2 & 3.4 & 5.1 \\
\hline Plus: import taxes $2 /$ & 1.9 & 2.7 & 5.4 & 8.9 & -0.5 \\
\hline less: imputex banking services & -0.5 & 8,1 & 11.8 & 22.0 & 16.8 \\
\hline \multicolumn{6}{|c|}{ (Percent distribution) } \\
\hline Gross domestic product at 1982 market prices & 1000 & 100.0 & 100.0 & 100.0 & 100.0 \\
\hline Primary activity & 8.4 & 8.2 & 7.9 & 8.1 & 7.9 \\
\hline Aqrioulture & 8.2 & 8.1 & 7.7 & 7.9 & 7.6 \\
\hline Mining & 0.1 & 0.1 & 0.2 & 0.2 & 0.2 \\
\hline Secondary activity & 14.1 & 13.4 & 13.6 & 13.7 & 13.4 \\
\hline Maoufacturing & 9.9 & 9.5 & 9.7 & 9.7 & 8.8 \\
\hline Constnuction & 4.2 & 3.9 & 3.9 & 4.0 & 4.5 \\
\hline Services & 77.2 & 78.2 & 78.5 & 78.8 & 80.2 \\
\hline Public utilities & 4.2 & 4.8 & 4.6 & 4.2 & 49 \\
\hline \multicolumn{6}{|l|}{ Commerce, restaurants, } \\
\hline and hotels & 20.7 & 19.9 & 20.7 & 20.3 & 19.2 \\
\hline Colon Free Zone wholessate & 8.3 & 7.7 & 8.6 & 80 & 6.6 \\
\hline Restaurants anc hotels & 1.5 & 1.6 & 1.6 & 1.6 & 3.6 \\
\hline Other & 10.8 & 10.6 & 10.6 & 10.7 & 10.9 \\
\hline Transport and communications & 12.3 & 12.2 & 12.4 & 13.2 & 14.1 \\
\hline Panama Canal Conmission & 6.8 & 6.7 & 6.4 & 6.4 & 6.3 \\
\hline Other transport and communication & 5.5 & 5.5 & 6.0 & 6.8 & 7.7 \\
\hline Finsncial internediationt & 10.4 & 11.4 & 11.8 & 11.7 & 12.4 \\
\hline Fousing & 13.6 & 13.8 & 13.7 & 13.5 & 13.7 \\
\hline Public admimistration & 10.5 & 10.4 & 10.4 & 10.2 & 10.1 \\
\hline Other services & 5.6 & 5.7 & 5.8 & 5.7 & 5.8 \\
\hline Plus: import takes 2/ & 4.0 & 4,0 & 4.1 & 4.2 & 4.1 \\
\hline Less: irsquted banking services & 3.7 & 3.9 & 4.1 & 4.8 & 5.5 \\
\hline
\end{tabular}

Soumces: Office of the Comptraller General; and Fund staff estinates.

1/ The national accounts for 1980-94 were revised and published in December 1995. The base year for the constant price data was updated to 1982 from 1970 and methodological improvements were implemeated.

2/ Ineludes the sales tax: "impuesto a la transferencia de bienes muebles." 
Table 6. Panama: National Accounts by Use

\begin{tabular}{|c|c|c|c|c|c|}
\hline & 1995 & 1996 & 1997 & 1998 & 1999 \\
\hline \multicolumn{6}{|c|}{ (In milticas of balboas at current prices) } \\
\hline Total domestie demand & $8,063.4$ & $8,270.6$ & $8,984.9$ & $9,980.5$ & $10,346.5$ \\
\hline Consumption & $5,669.2$ & $\$, 783.2$ & $6,293.8$ & $6,983.3$ & $7,237.3$ \\
\hline Public & $1,029.7$ & $1,055.4$ & $1,176.2$ & $1,238.6$ & $1,319.5$ \\
\hline Private & $4,639.5$ & $4,727.8$ & $5,117,6$ & 5.744 .7 & $5,917,8$ \\
\hline Gross domestic investment & $2,394,2$ & $2,487,4$ & $2,691.1$ & $2,997.2$ & $3,109,2$ \\
\hline Public & 272.0 & $\mathbf{3 1 3 . 4}$ & 385.4 & 581.1 & 457.2 \\
\hline Privente $1 /$ & $2,122.2$ & $2,174,0$ & $2,305.7$ & $2,416.1$ & $2,652.0$ \\
\hline Balance of trade (goods and nonfactor serviees) & -157.3 & $-\$ 19.5$ & -327.4 & -836.7 & -801.1 \\
\hline Balance excluding the Cojon Fre Zoris & -389.8 & -459.1 & -902.7 & 839.6 & -763.0 \\
\hline Exports of goods and nonfactor vervicen & $7,610.3$ & $7,381.5$ & $8,318.1$ & $8,047.1$ & $7,019.0$ \\
\hline Exports excluding the Colon Fitec Zone & $1,176.0$ & $1,265.2$ & $1,201.7$ & $1,387.4$ & $1,480.0$ \\
\hline Imports of goods and nonfactor services & $7,767.6$ & 7,5010 & $8,645.5$ & $8,883.8$ & $7,820.1$ \\
\hline Imports excluding the Colon Free Zone & $1,565.8$ & $1,724,3$ & $2,104.4$ & $2,727.0$ & $2,243.0$ \\
\hline Gross domestio product at curment market prices & $7,906.1$ & $8,151.1$ & $8,657.5$ & $9,143.8$ & $9,545,4$ \\
\hline \multicolumn{6}{|c|}{ (In peroent of GDP) } \\
\hline Total domestic demand & 101.9 & 101.4 & 103.8 & 109.1 & 108.4 \\
\hline Consumption & 71.7 & 70.9 & 72.7 & 76.3 & 75.8 \\
\hline Public & 13.0 & 12.9 & 13.6 & 13.5 & 13.8 \\
\hline Private & 58.7 & 58 & 59.1 & 62.8 & 62 \\
\hline Gross domestic investment & 30.2 & 30.5 & 31.1 & 32.8 & 32.6 \\
\hline Public & 3.4 & 3.8 & 4.5 & 6.4 & 4.8 \\
\hline Private $1 /$ & 26.8 & 26.7 & 25.6 & 26.4 & 27.8 \\
\hline \multicolumn{6}{|c|}{ (In percent of GDP) } \\
\hline Balance of trade (goods and nonfactor savices) & -2 & -1.5 & -3.8 & -92 & -8.4 \\
\hline Batano excluding the Colon Free Zone & -4.9 & -5.6 & -10.4 & -9.2 & -8.0 \\
\hline Exports of goods and norfactor services & 96.3 & 90.6 & 96.1 & 88 & 73.5 \\
\hline Exports excluding the Colon Free Zone & 14.9 & 15.5 & 13.9 & 15.7 & 15.5 \\
\hline Imports of goods and nonfactor sorvices & 98.2 & 92 & 99.9 & 97.2 & 81.9 \\
\hline Imports excluding the Colon Free Zone & 19.8 & 21.2 & 24.3 & 24.4 & 23.5 \\
\hline Gross domestic praduct at current market prices & 100.0 & 100.0 & 100.0 & 100.0 & 100.0 \\
\hline \multicolumn{6}{|c|}{ (Percentage change) } \\
\hline Total domeatic densand & 5.5 & 2.6 & 8.6 & 11.1 & 3.7 \\
\hline Consufleption & -2.5 & 2.0 & 8.8 & 11.0 & 3.6 \\
\hline Public & 2.2 & 2.5 & 11.4 & 5.3 & 6.5 \\
\hline Private & .3 .5 & 1.9 & 8.2 & 12.3 & 3.0 \\
\hline Oross domestic investrueant & 30.9 & 3.9 & 8.2 & 11.4 & 3.7 \\
\hline Public & 2.0 & 15.2 & 23.0 & 50.8 & -21.3 \\
\hline Private 1f & 35.9 & 2.4 & 6.1 & 4.8 & 9.8 \\
\hline Exports of goods and nonfactor services & 2.2 & $-3,0$ & 12.7 & -3.3 & -12.8 \\
\hline Exports excluding the Colon Free Zone & -43.2 & 7.6 & -5.0 & 15.5 & 6.7 \\
\hline imports of goods and nonfactor services & 5.5 & -3.4 & 15.3 & 2.8 & -12.0 \\
\hline Imports excluding the Colon Free Zone & -45.9 & 10.1 & 22.0 & 5.8 & 0.7 \\
\hline Gross domestic product at clufrent market prices & 2.2 & 3.1 & 6.2 & 5.6 & 4.4 \\
\hline
\end{tabular}

Sourcs: Office of the Comptrolher General; and Fund staff estimates.

1/ Includes changes in inventories. 
Table 7. Panama: Savings and Investment

\begin{tabular}{|c|c|c|c|c|c|}
\hline & 1995 & 1996 & 1997 & 1998 & 1999 \\
\hline \multicolumn{6}{|c|}{ (In millions of baIboas) } \\
\hline Gross domestic investment & $2,394.2$ & $2,487.4$ & $2,691.1$ & $2,997.2$ & $3,109.2$ \\
\hline Fixed capital formation (gross) & $2,057.9$ & $2,059.2$ & $2,295,0$ & $2,624.9$ & 2,831 .2 \\
\hline Public sector & 272.0 & 313.4 & 385.4 & 581.1 & 457.2 \\
\hline Private sector & $1,785.9$ & $1,745.8$ & $1,909.6$ & $2,043.8$ & $2,374,0$ \\
\hline Changes in inventories & 336.3 & 428.2 & 396.1 & 372.3 & 278.0 \\
\hline Gross national savings & $2,025.1$ & 2,185.5 & $2,102.7$ & $1,795.0$ & $1,731.7$ \\
\hline Public sector savings & 262.8 & 323.9 & 259.9 & 224.0 & 273.7 \\
\hline Private sector savings & $1,762.3$ & $1,861.6$ & $1,842.8$ & $1,571.0$ & $1,458.0$ \\
\hline Foreign savings & 369.1 & 301.9 & 588.4 & 1202.2 & 1377.5 \\
\hline \multicolumn{6}{|c|}{ (In percent of GDP) } \\
\hline Gross domestic investment & 30.3 & 30.5 & 31.1 & 32.8 & 32.6 \\
\hline Fixed capital formation (gross) & 26.0 & 25.3 & 26.5 & 28.7 & 29.7 \\
\hline Public sector & 3.4 & 3.8 & 4.5 & 6.4 & 4.8 \\
\hline Private sector & 22.6 & 21.4 & 22.1 & 22.4 & 24.9 \\
\hline Changes in inventories & 4.3 & 5.3 & 4.6 & 4.1 & 2.9 \\
\hline Gross mational savings & 25.6 & 26.8 & 24.3 & 19.7 & 18.2 \\
\hline Public sector savings & 3.3 & 4.0 & 3.0 & 2.4 & 2.9 \\
\hline Private sector savings & 22.3 & 22.8 & 21.3 & 17.3 & 15.3 \\
\hline Foreign savings & 4.7 & 3.7 & 6.8 & 13.1 & 14.4 \\
\hline
\end{tabular}

Sources: Office of the Comptroller General; and Fund staff estimates. 
Table 8. Panama: Agricultural Production

\begin{tabular}{|c|c|c|c|c|c|}
\hline & 1994 & 1995 & 1996 & 1997 & 1998 \\
\hline \multicolumn{6}{|c|}{ (In millions of balboas at 1982 prices) } \\
\hline Total & 493.3 & 309.2 & 515.0 & 514.9 & 545.1 \\
\hline Crops & 269.0 & 262.9 & 261.6 & 242.3 & 244.4 \\
\hline Rice & 32.3 & 33.2 & 36.0 & 25.0 & 40.0 \\
\hline Corn & 17.3 & 17.6 & 18.2 & 13.7 & 16.5 \\
\hline Bananas & 136.1 & 126.6 & 117.6 & 112.4 & 86.0 \\
\hline Sugarcane & 19.3 & 18.2 & 19.6 & 21.7 & 23.9 \\
\hline Coffee & 13.2 & 15.0 & 15.5 & 14.6 & 15.9 \\
\hline Other & 50.8 & 52.3 & 54.7 & 54.9 & 62.1 \\
\hline Livestock & 157.3 & 159.3 & 167.5 & 174.2 & 188.0 \\
\hline Forestry & 14.6 & 12.8 & 12.0 & 12.7 & 12.7 \\
\hline Fish & 52.4 & 74.2 & 73.9 & 85.7 & 100.0 \\
\hline \multicolumn{6}{|c|}{ (Annual percent change) } \\
\hline Total & 2.7 & 3.2 & 1.1 & 0.0 & 5.9 \\
\hline Crops & 3.7 & -2.3 & -0.5 & -7.4 & 0.9 \\
\hline Livestock & 1.5 & 1.3 & 5.1 & 4.0 & 7.9 \\
\hline Forestry & -0.7 & -12.3 & -6.3 & 5.8 & 0.0 \\
\hline Fish & 2.1 & 41.6 & -0.4 & 16.0 & 16.7 \\
\hline
\end{tabular}

Sources: Office of the Comptroller General; and Fund staff estimates. 
Table 9. Panama: Value-Added in Manufacturing

\begin{tabular}{|c|c|c|c|c|c|}
\hline & 1994 & 1995 & 1996 & 1997 & 1998 \\
\hline \multicolumn{6}{|c|}{ (In millions of balboas at 1982 prices) } \\
\hline Total & 614.6 & 615.8 & 608.1 & 646.8 & 673.4 \\
\hline Food & 237,1 & 245.5 & 246.4 & 265.5 & 295.2 \\
\hline Beverages & 53.7 & 52.7 & 53.3 & 58.4 & 63.2 \\
\hline Tobacco & 27.8 & 27.2 & 29.2 & 28.6 & 8.2 \\
\hline Petroleufn products & I5.1 & 10.5 & 17.3 & 17.5 & 19.3 \\
\hline Textiles and garments & 38.1 & 34.4 & 30.3 & 27.8 & 25.8 \\
\hline Leather products and footwear & 11.6 & 13.0 & 10.9 & 9.8 & 8.7 \\
\hline Wood and furniture & 31.4 & 27.6 & 28.4 & 31.1 & 35.8 \\
\hline Paper products & 29,9 & 30.6 & 27.8 & 25.9 & 23.3 \\
\hline Printing and publishing & 15.2 & 16.2 & 12.0 & 11.9 & 16.8 \\
\hline Chemicals, nubber and plastic products & 57.6 & 59.3 & 55.2 & 57.3 & 56.8 \\
\hline Glass and other mineral products & 49.9 & 45.2 & 41.3 & 46.3 & 52.9 \\
\hline Basic metal industries & 9.8 & 10.9 & 13.7 & 18.0 & 20.4 \\
\hline \multicolumn{6}{|l|}{ Metal products, machinery, and } \\
\hline equipment & 21.5 & 22.7 & 22.2 & 26.0 & 28.0 \\
\hline Other & 15.9 & 20.0 & 20.1 & 22.7 & 19.0 \\
\hline \multicolumn{6}{|c|}{ (Annual percent change) } \\
\hline Total & 4.3 & 0.2 & -1.3 & 6.4 & 4.1 \\
\hline Petroleum products & -28.4 & -30.5 & 64,8 & 1.2 & 10.3 \\
\hline Total (excluding petroleum products) & 5.5 & 1.0 & -2.4 & 5.5 & 3.9 \\
\hline Food, beverages, and tobacco & 5.7 & 2.1 & 1.1 & 7.2 & 4.0 \\
\hline Other products & 5.2 & -0.4 & -6.4 & 5.7 & 3.9 \\
\hline
\end{tabular}

Sources: Office of the Comptroller General; and Fund staff estimates. 
Table 10. Panama: Electricity Generation and Consumption (In thousands of gigawatt hours) $1 /$

\begin{tabular}{llllll}
\hline & 1994 & 1995 & 1996 & 1997 & 1998 \\
\hline Net generation & $\mathbf{3 . 3 6}$ & $\mathbf{3 . 5 2}$ & $\mathbf{3 . 8 2}$ & $\mathbf{4 . 0 5}$ & $\mathbf{4 . 1 8}$ \\
Hydro & 2.39 & 2.42 & 3.00 & 2.90 & 2.14 \\
Thermal & 0.97 & 1.10 & 0.82 & 1.15 & 2.04 \\
& & & & & \\
Total comsumption & $\mathbf{2 . 6 7}$ & $\mathbf{2 . 8 7}$ & $\mathbf{2 . 9 8}$ & $\mathbf{3 . 3 0}$ & $\mathbf{3 . 4 1}$ \\
Residential & 0.79 & 0.85 & 0.86 & 0.94 & 1.00 \\
Commercial & 0.91 & 1.00 & 1.04 & 1.18 & 1.34 \\
Industrial & 0.43 & 0.46 & 0.47 & 0.47 & 0.49 \\
Government & 0.47 & 0.53 & 0.55 & 0.57 & 0.54 \\
Petroterminal & 0.01 & 0.01 & 0.00 & 0.00 & 0.00 \\
Other & 0.06 & 0.02 & 0.06 & 0.14 & 0.04 \\
& & & & & \\
\hline
\end{tabular}

Sources: Hydraulic Resources and Electricity Institute (TRHE); and Fund staff estimates.

1/ A gigawatt hour is equal to one billion watts being generated or consumed for one hour. 
Table 11. Panama: Private Sector Construction Permits, District of Panama

(In thousands of square meters)

\begin{tabular}{lrrrrr}
\hline & 1994 & 1995 & 1996 & 1997 & 1998 \\
\hline Total & 912.4 & 827.9 & 925.3 & 795.6 & 535.5 \\
Residential & 550.4 & 505.8 & 430.0 & 407.7 & 283.4 \\
Conmercial & 299.7 & 227.0 & 438.9 & 360.3 & 222.5 \\
Industrial & 14.8 & 14.4 & 26.8 & 3.8 & 3.5 \\
Other & 47.6 & 30.7 & 29.6 & 23.8 & 26.1 \\
\hline
\end{tabular}

Sources: Office of the Comptroller General; and Fund staff estimates. 
Table 12. Panama: Domestic Sales of Petroleum

\begin{tabular}{|c|c|c|c|c|c|}
\hline & 1994 & 1995 & 1996 & 1997 & 1998 \\
\hline \multicolumn{6}{|c|}{ (In mithions of balboas) } \\
\hline Domestic sales & 200.0 & 222.5 & 255.8 & 309.1 & 275.2 \\
\hline Gasoline & 59.9 & 69.0 & 80.5 & 87.7 & 75.3 \\
\hline Diesel & 88.5 & 93.7 & 103.8 & 126.9 & 120.5 \\
\hline Fuel oil & 27,3 & 34.3 & 39.8 & 35.6 & 34.9 \\
\hline Kerosene & 2.2 & 2.1 & 2.0 & 3.1 & 2.9 \\
\hline LP gas & 17.3 & 19.4 & 22.1 & 33.1 & 21.9 \\
\hline Other products $1 /$ & 4.8 & 4,0 & 7.6 & 22.7 & 19.7 \\
\hline \multicolumn{6}{|c|}{ (In millions of barrels) } \\
\hline Domestic sales & 9.0 & 9.7 & 9.8 & 10.8 & 12.8 \\
\hline Gasoline & 2.4 & 2.6 & 2.7 & 2.9 & 3.2 \\
\hline Diesel & 3.7 & 4.1 & 3.6 & 4.3 & 5.3 \\
\hline Fuel oil & 1.7 & 1.8 & 1.9 & 1.7 & 2.2 \\
\hline Kerosene & 0.1 & 0.1 & 0.1 & 0.1 & 0.1 \\
\hline LP gas & 0.9 & 0.9 & 1.0 & 1.0 & 1.1 \\
\hline Other products $1 /$ & 0.2 & 0.2 & 0.5 & 0.8 & 0.9 \\
\hline
\end{tabular}

Sources: Ministry of Commerce and Industry; and Fund staff estimates.

1/ Includes marine diesel. 
Table 13. Panama: Labor Force Statistics

\begin{tabular}{|c|c|c|c|c|c|c|}
\hline & 1995 & 1996 & 1997 & 1998 & 1999 & 200011 \\
\hline \multicolumn{7}{|c|}{ (In thousands of persons) } \\
\hline Total population & $2,631.0$ & $2,674.5$ & 2,718.7 & $2,764.9$ & $2,811.9$ & $2,855.7$ \\
\hline Working age population & $1,632,4$ & $1,670.2$ & $1,706.8$ & $1,742.9$ & $1,779.1$ & $1,814.8$ \\
\hline Total Labor force 2 & $1,007.9$ & $1,012.1$ & $1,049.4$ & $1,083.6$ & $1,089.4$ & $1,086.6$ \\
\hline Employment by activity & 866.7 & 867.2 & 909.1 & 936.5 & 961.4 & 942.0 \\
\hline Agriculture and mining & 181.9 & 176.0 & 171.6 & 167.3 & 168.4 & 163.0 \\
\hline Manufacturing & 92.6 & 94.0 & 96.2 & 90.6 & 94.0 & 85.3 \\
\hline Public utilities & 8.8 & 9.1 & 9.1 & 9.4 & 7.0 & 6.9 \\
\hline Construction & 53,6 & 54,9 & 59.6 & 67.9 & 73.0 & 69.2 \\
\hline Commerce & 152.1 & 153.0 & 168.1 & 177.5 & 182.7 & 181.0 \\
\hline Banking & 19.7 & 22.1 & 22.8 & 24.4 & 23.9 & 27.3 \\
\hline Transportation and communi & 63.4 & 59.0 & 62.1 & 63.7 & 73.0 & 71.7 \\
\hline Other services & 294.6 & 299.1 & 319.6 & 335.7 & 339.4 & 333,6 \\
\hline Unemployment & 141.3 & 144.9 & 140.3 & 147.1 & 128.0 & 144.6 \\
\hline Unemployment rate & 14.0 & 14.3 & 13.4 & 13.6 & 11.8 & 13.3 \\
\hline \multicolumn{7}{|l|}{$\begin{array}{l}\text { Memorandum items: } \\
\text { Number of employed by: }\end{array}$} \\
\hline Employment by sector & 866.7 & 867.2 & 909.1 & 936.5 & 961.4 & 942.0 \\
\hline Public sector & 161.4 & 160.2 & 161.8 & 167.2 & 156.1 & 171.6 \\
\hline Private business & 354.3 & 359.4 & 372.7 & 394.3 & 424.1 & 401.6 \\
\hline Self-employed & 247.0 & 250.3 & 275.9 & 282.6 & 296.1 & 291.3 \\
\hline Other & 103.9 & 97.3 & 98.7 & 92.4 & 85.0 & 77.5 \\
\hline \multicolumn{7}{|c|}{ (Annual percent change) } \\
\hline Total population & 1.9 & 1.7 & 1.7 & 1.7 & 1.7 & 1.6 \\
\hline Working age population & 2.4 & 2.3 & 2.2 & 2.1 & 2.1 & 2.0 \\
\hline Total labor force & 4.2 & 0.4 & 3.7 & 3.3 & 0.5 & $-0,3$ \\
\hline Employed & 4,2 & 0.1 & 4.8 & 3.0 & 2.7 & -2.0 \\
\hline Unemployed & 4.3 & 2.5 & -3.2 & 4.9 & -13.0 & 12.9 \\
\hline \multicolumn{7}{|c|}{ (In percent) } \\
\hline Labor force participation rate 3/ & 61.7 & 60.6 & 61.5 & 62.2 & 61.2 & 59,9 \\
\hline Employment rate 4/ & 53.1 & 51.9 & 53.3 & 53.7 & 54.0 & 51.9 \\
\hline Unemployment rate & 14.0 & 14.3 & 13.4 & 13.6 & 11.8 & 13.3 \\
\hline Of which & & & & & & \\
\hline Metropolitan areas 5/ & 16.6 & 16.9 & 15.4 & 16.0 & 13.8 & 15.2 \\
\hline
\end{tabular}

Sources: Ministry of Labor; Office of the Comptroller General; and Fund staff estimates.

1/ As of August 2000 household survey.

2/ Excludes indigenous population, canal area and collective housing, but includes employees in the formal and informal sectors, employers, and the self employed.

3/ Total labor force as a percent of the working-age population.

4/ Employed labor force as a percent of the working-age population.

5/ Comprises the cities of Panama and Colon. 
Table 14. Panama: Average Prices Received by Farmers

\begin{tabular}{lrrrrr}
\hline & 1994 & 1995 & 1996 & 1997 & 1998 \\
\hline & (In balboas per unit) & & & & \\
& & & & & \\
Rice (100 lb.) 1/ & 12.56 & 12.87 & 11.91 & 12.32 & 12.68 \\
Com (100 lb.) & 11.67 & 11.86 & 12.34 & 12.26 & 12.61 \\
Beans (100 lb.) 2/ & 33.12 & 35.13 & 32.77 & 38.53 & 35.43 \\
Potatoes (100 lb.) & 26.29 & 23.40 & 24.72 & 19.30 & 21.81 \\
Bananas stalk & 2.68 & 2.17 & 2.61 & 2.76 & 2.82 \\
Chicken (live, lb.) & 1.23 & 1.24 & 1.21 & 1.23 & 1.25 \\
Milk, fresh (bottle) & 0.30 & 0.29 & 0.27 & 0.28 & 0.28 \\
& & & & & \\
& (In 1987 prices) $3 /$ & & & & \\
Rice (100 bb.) 1/ & & & & & \\
Corn (100 lb.) & 11.07 & 11.37 & 10.73 & 11.03 & 11.18 \\
Beans (100 lb.) 2/ & 10.29 & 10.48 & 11.11 & 10.97 & 11.12 \\
Potatoes (100 lb.) & 29.19 & 31.04 & 29.52 & 34.49 & 31.24 \\
Bananas stalk & 23.17 & 20.68 & 22.27 & 17.27 & 19.23 \\
Chicken (live, lb.) & 2.36 & 1.92 & 2.35 & 2.47 & 2.49 \\
Milk, fresh (bottle) & 1.08 & 1.10 & 1.09 & 1.10 & 1.10 \\
& 0.26 & 0.26 & 0.24 & 0.25 & 0.25 \\
\hline
\end{tabular}

Sources: Office of the Comptroller Generat; and Fund staff estimates.

1/ First grade.

2/ Colorado or Chiricano.

3/ Deflated by the agricultural wholesale price index. 
Table 15. Panama: Selected Price Indices 1/

(Annual percent change)

\begin{tabular}{|c|c|c|c|c|c|}
\hline & 1995 & 1996 & 1997 & 1998 & 1999 \\
\hline \multicolumn{6}{|c|}{ (Period average) } \\
\hline Consumer price index & 0.9 & 1.3 & 1.2 & 0.6 & 1.4 \\
\hline Wholesale price index & 3.0 & 2.1 & -2.2 & -3.9 & 2.7 \\
\hline Imports & 3.9 & 3.8 & -4.1 & -5.7 & 6.0 \\
\hline Industrial products & 2.7 & 1.3 & -0.9 & -3.3 & -0.3 \\
\hline Agricultural products & -0.2 & -1.9 & 0.6 & 1.5 & 0.8 \\
\hline GDP deflator & 0.5 & 0.3 & 1.7 & 1,2 & 1.4 \\
\hline \multicolumn{6}{|c|}{ (End of period) } \\
\hline Consumer price index & 0.8 & 2.3 & -0.5 & 1.4 & 1.5 \\
\hline Wbolesale price index & 1.8 & 3.5 & -3.9 & -3.9 & 6.8 \\
\hline Imports & 2.8 & 6.0 & $-6,3$ & -5.6 & 12.2 \\
\hline Industrial products & 1.5 & 2.2 & -2.5 & -3.4 & 2.9 \\
\hline Agricultural products & -1.0 & -0.9 & 0.8 & 1.3 & 0.9 \\
\hline
\end{tabular}

Sources: Office of the Comptroller General; and Fund staff estimates.

1/ The consumer and wholesale price indices use 1987 as the reference period. 
Table 16. Panama: Consumer Price Index

$(1987=100)$

\begin{tabular}{|c|c|c|c|c|c|}
\hline & Total & Food & Clothing & Housing & Miscellaneous \\
\hline \multicolumn{6}{|c|}{ (In percent) } \\
\hline Weights: & 100.0 & 34.9 & 5.1 & 21.0 & 39.0 \\
\hline \multicolumn{6}{|c|}{ (Period average) } \\
\hline $\begin{array}{l}1995 \\
1996 \\
1997 \\
1998 \\
1999\end{array}$ & $\begin{array}{l}107.5 \\
108.9 \\
110.2 \\
110.9 \\
112.4\end{array}$ & $\begin{array}{l}110.6 \\
111.4 \\
112.2 \\
112.6 \\
112.8\end{array}$ & $\begin{array}{l}110.0 \\
109.0 \\
106.8 \\
108.2 \\
108.6\end{array}$ & $\begin{array}{l}105.4 \\
108.2 \\
110.5 \\
111.7 \\
114.6\end{array}$ & $\begin{array}{l}105.5 \\
106.9 \\
108.7 \\
109.4 \\
111.3\end{array}$ \\
\hline \multicolumn{6}{|c|}{ (End of period) } \\
\hline $\begin{array}{l}1995 \\
1996 \\
1997 \\
1998 \\
1999\end{array}$ & $\begin{array}{l}108.1 \\
110.6 \\
110.1 \\
111.6 \\
113.3\end{array}$ & $\begin{array}{l}111.7 \\
113.6 \\
112.6 \\
112.3 \\
114.1\end{array}$ & $\begin{array}{l}109.4 \\
108.8 \\
106.4 \\
108.4 \\
107.8\end{array}$ & $\begin{array}{l}106.5 \\
110.2 \\
110.6 \\
114.7 \\
114.5\end{array}$ & $\begin{array}{l}105.6 \\
108.4 \\
108.1 \\
109.9 \\
112.7\end{array}$ \\
\hline $\begin{array}{l}1996 \\
\text { March } \\
\text { June } \\
\text { September } \\
\text { Decernber }\end{array}$ & $\begin{array}{l}108.4 \\
108.3 \\
109.1 \\
110.6\end{array}$ & $\begin{array}{l}111.3 \\
110.2 \\
111.9 \\
113.6\end{array}$ & $\begin{array}{l}110.2 \\
107.6 \\
109.3 \\
108.8\end{array}$ & $\begin{array}{l}107.0 \\
107.9 \\
108.7 \\
110.2\end{array}$ & $\begin{array}{l}106.4 \\
106.9 \\
106.9 \\
108.4\end{array}$ \\
\hline $\begin{array}{l}1997 \\
\text { March } \\
\text { June } \\
\text { September } \\
\text { December }\end{array}$ & $\begin{array}{l}109.9 \\
110.3 \\
110.6 \\
110.1\end{array}$ & $\begin{array}{l}111.9 \\
112.0 \\
112.7 \\
112.6\end{array}$ & $\begin{array}{l}108.2 \\
106.5 \\
104.4 \\
106.4\end{array}$ & $\begin{array}{l}109.7 \\
110.5 \\
110.8 \\
110.6\end{array}$ & $\begin{array}{l}108.7 \\
109.1 \\
109.4 \\
108.1\end{array}$ \\
\hline $\begin{array}{l}1998 \\
\text { March } \\
\text { June } \\
\text { September } \\
\text { December }\end{array}$ & $\begin{array}{l}110.4 \\
110.8 \\
111.5 \\
111.6\end{array}$ & $\begin{array}{l}112.2 \\
112.7 \\
112.7 \\
112.3\end{array}$ & $\begin{array}{l}108.3 \\
108.2 \\
108.1 \\
108.4\end{array}$ & $\begin{array}{l}110.5 \\
110.5 \\
113.2 \\
114.7\end{array}$ & $\begin{array}{l}108.9 \\
109.7 \\
110.0 \\
109.9\end{array}$ \\
\hline $\begin{array}{l}1999 \\
\text { March } \\
\text { June }\end{array}$ & $\begin{array}{l}112.0 \\
112.3\end{array}$ & $\begin{array}{l}112.5 \\
112.4\end{array}$ & $\begin{array}{l}108.9 \\
109.2\end{array}$ & $\begin{array}{l}114.5 \\
114.8\end{array}$ & $\begin{array}{l}110.4 \\
111.3\end{array}$ \\
\hline $\begin{array}{l}\text { September } \\
\text { December }\end{array}$ & $\begin{array}{l}112.6 \\
113.3\end{array}$ & $\begin{array}{l}112.4 \\
114.1\end{array}$ & $\begin{array}{l}108.9 \\
107.8\end{array}$ & $\begin{array}{l}114.8 \\
114.5\end{array}$ & $\begin{array}{l}112.2 \\
112.7\end{array}$ \\
\hline $\begin{array}{l}2000 \\
\text { March } \\
\text { June } \\
\text { September }\end{array}$ & $\begin{array}{l}114.0 \\
114.2 \\
114.2\end{array}$ & $\begin{array}{l}113.0 \\
113.6 \\
113.3\end{array}$ & $\begin{array}{l}108.2 \\
108.9 \\
109.1\end{array}$ & $\begin{array}{l}117.3 \\
117.1 \\
117.1\end{array}$ & $\begin{array}{l}113.9 \\
113.9 \\
113.9\end{array}$ \\
\hline
\end{tabular}

Sources. Office of the Comptroller General; and Fund staff estimates. 
Table 17. Panama: Wholesale Price Index

\begin{tabular}{|c|c|c|c|c|}
\hline \multicolumn{5}{|c|}{$(1987=100)$} \\
\hline & Total & Imports & Industrial & Agricultural \\
\hline \multicolumn{5}{|c|}{ (Int percent) } \\
\hline Weights & 100.0 & 43.7 & 45.1 & 11.2 \\
\hline \multicolumn{5}{|c|}{ (Period average) } \\
\hline $\begin{array}{l}1995 \\
1996 \\
1997 \\
1998 \\
1999\end{array}$ & $\begin{array}{l}115.7 \\
118.2 \\
115.5 \\
111.0 \\
114.0\end{array}$ & $\begin{array}{l}121.5 \\
126.2 \\
121.0 \\
114.1 \\
120.9\end{array}$ & $\begin{array}{l}110.8 \\
112.3 \\
111.2 \\
107.6 \\
107.3\end{array}$ & $\begin{array}{l}113.2 \\
111.0 \\
111.7 \\
113.4 \\
114.3\end{array}$ \\
\hline \multicolumn{5}{|c|}{ (End of period) } \\
\hline $\begin{array}{l}1995 \\
1996 \\
1997 \\
1998 \\
1999\end{array}$ & $\begin{array}{l}116.2 \\
120.3 \\
115.6 \\
111.1 \\
118.7\end{array}$ & $\begin{array}{l}121.9 \\
129.2 \\
121.1 \\
114.5 \\
128.3\end{array}$ & $\begin{array}{l}111.4 \\
113.8 \\
111.0 \\
107.2 \\
110.3\end{array}$ & $\begin{array}{l}113.2 \\
112.2 \\
113.1 \\
114.8 \\
115.6\end{array}$ \\
\hline $\begin{array}{l}1996 \\
\text { March } \\
\text { June } \\
\text { September } \\
\text { December }\end{array}$ & $\begin{array}{l}117.8 \\
117.0 \\
117.6 \\
120.3\end{array}$ & $\begin{array}{l}126.3 \\
124.3 \\
125.0 \\
129.2\end{array}$ & $\begin{array}{l}111.6 \\
111.4 \\
112.2 \\
113.8\end{array}$ & $\begin{array}{l}109.9 \\
111.0 \\
111.0 \\
112.2\end{array}$ \\
\hline $\begin{array}{l}1997 \\
\text { March } \\
\text { June } \\
\text { September } \\
\text { December }\end{array}$ & $\begin{array}{l}115.8 \\
115.4 \\
115.3 \\
115.6\end{array}$ & $\begin{array}{l}121.3 \\
120.8 \\
120.7 \\
121.1\end{array}$ & $\begin{array}{l}111.7 \\
111.2 \\
111.0 \\
111.0\end{array}$ & $\begin{array}{l}111.0 \\
111.1 \\
111.7 \\
113.1\end{array}$ \\
\hline $\begin{array}{l}1998 \\
\text { March } \\
\text { June } \\
\text { September } \\
\text { December }\end{array}$ & $\begin{array}{l}111.6 \\
111.1 \\
110.2 \\
111.1\end{array}$ & $\begin{array}{l}115.1 \\
113.9 \\
112.9 \\
114.3\end{array}$ & $\begin{array}{l}108.1 \\
108.0 \\
107.1 \\
107.2\end{array}$ & $\begin{array}{l}112.8 \\
113.2 \\
112.8 \\
114.6\end{array}$ \\
\hline $\begin{array}{l}1999 \\
\text { March } \\
\text { June } \\
\text { September } \\
\text { December }\end{array}$ & $\begin{array}{l}109.3 \\
111.5 \\
116.4 \\
118.7\end{array}$ & $\begin{array}{l}112.1 \\
118.6 \\
124.7 \\
128.3\end{array}$ & $\begin{array}{l}105.6 \\
104.3 \\
109.1 \\
110.3\end{array}$ & $\begin{array}{l}113.6 \\
114.1 \\
113.8 \\
115.6\end{array}$ \\
\hline $\begin{array}{l}2000 \\
\text { March } \\
\text { June } \\
\text { September }\end{array}$ & $\begin{array}{l}121.2 \\
123.0 \\
124.4\end{array}$ & $\begin{array}{l}131.2 \\
135.0 \\
138.3\end{array}$ & $\begin{array}{l}113.7 \\
113.2 \\
113.3\end{array}$ & $\begin{array}{l}112.9 \\
115.8 \\
115.3\end{array}$ \\
\hline
\end{tabular}

Sources: Office of the Comptroller General; and Fund staff estimates. 
Table 18. Panama: Selected Energy Prices

\begin{tabular}{lcrrrr}
\hline & 1994 & 1995 & 1996 & 1997 & 1998 \\
\hline & (Balboas per megawatt hour) & & & \\
Electrictity rates 1/ & & & & & \\
Weighted average & 115.5 & 115.5 & 112.8 & 111.6 & $\ldots$ \\
$\quad$ Residential & 120.5 & 120.5 & 120.5 & 118.0 & $\ldots$ \\
$\quad$ Commercial & 119.2 & 119.2 & 119.5 & 118.1 & $\ldots$ \\
Industrial & 100.7 & 99.4 & 99.4 & 99.4 & $\ldots$ \\
Government & 103.4 & 112.7 & 111.6 & 111.0 & $\ldots$ \\
& & & & & \\
& - (Balboas per gallon) & & & & \\
Petraleum prices & & & & & \\
Gasoline premium & & & & & \\
Gasoline regular & 1.6 & 1.7 & 1.8 & 1.8 & 1.6 \\
Diesel & 1.5 & 1.6 & 1.7 & 1.7 & 1.5 \\
Kerosene & 1.1 & 1.2 & 1.3 & 1.3 & 1.1 \\
& 1.1 & 1.2 & 1.2 & 1.1 & 1.1 \\
\hline
\end{tabular}

Sources: Hydrautic Resources and Electricity Institute (IRHE); Ministry of Commerce and Industry; and Fund staff estimates.

1/ Panama's electricity system has recently been privatized. The price survey in operation under the old regime no longer applies, and a new one has not yet been instituted. 
Table 19. Panama: Operations of the Nonfinancial Public Sector

\begin{tabular}{|c|c|c|c|c|c|c|c|c|}
\hline & \multirow[b]{2}{*}{1994} & \multirow[b]{2}{*}{1995} & \multirow[b]{2}{*}{1996} & \multirow[b]{2}{*}{$199]$} & \multirow[b]{2}{*}{1998} & \multirow[b]{2}{*}{1999} & \multicolumn{2}{|c|}{$\begin{array}{c}\text { Preliminary } \\
\text { January - September }\end{array}$} \\
\hline & & & & & & & 1999 & 2000 \\
\hline \multicolumn{9}{|c|}{ (In millions of balboss) } \\
\hline Revenue & $2,292.0$ & $2,301.0$ & $2,271.2$ & $2,413.7$ & $2,529.0$ & $2,782.7$ & $2,023.7$ & $2,100.9$ \\
\hline General government revenue & $1,782.3$ & $1,933.4$ & $1,997.8$ & $2,118.3$ & 2.319 .7 & $2,645.4$ & $1,903.2$ & $1,978.2$ \\
\hline Central government & $1,204.3$ & $1,287.2$ & $1,325.9$ & $1,447.4$ & $1,582.5$ & 1.878 .3 & $1,318.8$ & $134\} .6$ \\
\hline Social security agency & 522.3 & 586.5 & 613.5 & 613.0 & 666.8 & 689.9 & 527.6 & 576.5 \\
\hline Decentral ized agencies & $\$ 5.7$ & 59.7 & 58.4 & 57.9 & 70.4 & 77.2 & 56.8 & 60.1 \\
\hline \multicolumn{9}{|l|}{ Public enterprises operating } \\
\hline balance (deficit $\cdot$ ) & 369.3 & 370.6 & 293.5 & 240.4 & 129.2 & 123.5 & 77.5 & 60.6 \\
\hline \multicolumn{9}{|l|}{ Overail balance of nonconsolidated } \\
\hline public sector (deficit -) & 12.2 & -18.0 & -16.0 & 20.8 & 70.0 & -22.5 & 6.4 & 33.6 \\
\hline Educational insutance balanct (deficit -) & 13.9 & -0.8 & .22 .7 & 4.1 & $-! 7.0$ & -4.1 & 2.1 & 4.3 \\
\hline Capital revenue & 24.3 & 15.8 & 18.6 & 30.1 & 27.1 & 40.4 & 34.5 & 24.2 \\
\hline Grants & 1.0 & 7.8 & 4.6 & 70.6 & 57.3 & 5.0 & 0.0 & 2.1 \\
\hline Expendlture & $2,178,5$ & $2,294.4$ & $2,242.1$ & $2,509.1$ & $2,854.1$ & $2,925.8$ & 2.326 .0 & $2,189.0$ \\
\hline General govemment current expendicure & 1.911 .8 & $2,022.4$ & $1,928.3$ & $2,123.7$ & $2,273.0$ & $2,468.6$ & 1.867 .5 & $1,932.5$ \\
\hline Certisal govemment & $1,146.7$ & $1,1.85 .6$ & $1,079.6$ & $1,207.3$ & $1,317.4$ & $1,482.2$ & $1, ; 40.8$ & 1151.2 \\
\hline Social security agency & 651.8 & 720.2 & 725,5 & 780.7 & 8152 & 846.0 & 622.4 & 674.7 \\
\hline Decentralized agencies & 113.3 & 116.7 & 123.5 & 135.7 & 140.4 & 140.4 & 104.3 & 106.6 \\
\hline Capital & 266.7 & 272.0 & 313.4 & 3.85 .4 & 581.1 & 457.2 & 458.5 & 256.5 \\
\hline Fixed investment & 237.4 & 243.1 & 279.5 & 338.1 & 525.9 & .. & $\ldots$ & $\ldots$ \\
\hline Transfers to private sector & 29.3 & 28.9 & 34,0 & 47.3 & $\$ \$ .2$ & $\ldots$ & $\ldots$ & $\ldots$ \\
\hline Saving $1 /$ & 265.9 & 262.8 & 323.9 & 259.9 & 228.9 & 273.7 & 121.7 & 144.2 \\
\hline Overall balance (deficit -) 2 ] & 24.5 & 14,4 & 33,6 & -34.8 & -267.8 & -138.1 & -302.3 & -86.0 \\
\hline Flngueing & -24.5 & -14.4 & -33.6 & 24.8 & 267.8 & 138.1 & 302.3 & 86.0 \\
\hline External & 119.0 & 206.4 & -146.1 & 190.3 & 454.4 & 254.9 & 317.9 & 170.4 \\
\hline Disbursements & 52.0 & 112.7 & 262.3 & $1,486.4$ & 703.1 & 630.0 & 603.1 & 448. $]$ \\
\hline Repayments & 271.0 & 262.6 & 328.7 & $1,249.0$ & 302.3 & 407.5 & 315.0 & 326 \\
\hline Debt reschedulitg & 481.0 & 77.7 & $3,342,8$ & 35.7 & $\$ 9.2$ & 32.3 & 29.8 & 24.6 \\
\hline Arrears & -143.0 & 278.6 & $-3,422.5$ & -67.8 & -29.8 & 00 & 0.0 & 0.0 \\
\hline Change if deposits abroad & 0.0 & 0.0 & 0.0 & -15.0 & 28.7 & 0.0 & 0.0 & 23.7 \\
\hline Domestic (net) & -193.5 & -220.8 & 117.9 & -161.3 & .162 .4 & -79.1 & 16.6 & -64.7 \\
\hline \multicolumn{9}{|l|}{ Of which: } \\
\hline Banking system & .277 .8 & -229.5 & 179.8 & -153.1 & -104.9 & -68.4 & 15.6 & -62.4 \\
\hline Arrears & 35.0 & 0.0 & 0.0 & 0.0 & 0.0 & 0.0 & 0.0 & 0.0 \\
\hline Privatization & 50.0 & 0.0 & 72.6 & 671.7 & 260.5 & 241.7 & 2414 & 1.1 \\
\hline Trist fund for development & 00 & 0.0 & .78 .0 & -675.9 & -284.8 & -279.4 & -273.6 & -20.8 \\
\hline
\end{tabular}


Table 19. Panama: Operations of the Nonfinancial Public Sector (Concluded)

\begin{tabular}{|c|c|c|c|c|c|c|c|c|}
\hline & \multirow[b]{2}{*}{1994} & \multirow[b]{2}{*}{1995} & \multirow[b]{2}{*}{1996} & \multirow[b]{2}{*}{1997} & \multirow[b]{2}{*}{1998} & \multirow[b]{2}{*}{1999} & \multicolumn{2}{|c|}{$\begin{array}{c}\text { Preliminery } \\
\text { January - September }\end{array}$} \\
\hline & & & & & & & 1999 & 2000 \\
\hline \multicolumn{9}{|c|}{ (Annual percent change) } \\
\hline Revenus & 7.1 & 4.5 & -1.3 & 6.3 & 4,8 & 10.0 & 9.5 & 3.8 \\
\hline Expenditure & 1.0 & 5.3 & -2.3 & 6.0 & 9.5 & 14,0 & 12.9 & 3,9 \\
\hline Current & 2.3 & 5.8 & -4.6 & 9.2 & 9.3 & 18.7 & 15.9 & 1.7 \\
\hline Capital & -7.7 & 2.0 & 15.2 & -0.1 & 8.8 & 3.5 & 6.2 & 9.3 \\
\hline \multicolumn{9}{|c|}{ (In percent of GDP 3/) } \\
\hline Revenue & 28.5 & 29.1 & 27.9 & 27.9 & 27.7 & 29.2 & 28.7 & 28,3 \\
\hline Grants & 0.0 & 0.1 & 0.1 & 0.8 & 0.6 & 0.1 & 0.0 & 0.0 \\
\hline Expendifure & 28.2 & 29.0 & 27.5 & 28.9 & 31.3 & 30.7 & 32.3 & 29,4 \\
\hline Current & 24.7 & 25.6 & 23.7 & 24.5 & 25.0 & 25.9 & 25.7 & 26,0 \\
\hline Capital & 3.4 & 3.4 & 3.8 & $4 . \hat{\jmath}$ & 6.4 & 4.8 & 6.6 & 3.5 \\
\hline Saving $1 /$ & $\mathbf{3 . 4}$ & $\mathbf{3 . 3}$ & 4,0 & 3.0 & 2.4 & 2.9 & 1.7 & 1.9 \\
\hline Overall balance (deficit-) $2 /$ & 6.3 & 0.2 & 0.4 & -0.3 & -2.9 & -1.4 & -3.6 & -1.2 \\
\hline Financing (net) & -0.3 & -0.2 & -0.4 & 0.3 & 2.9 & 1.4 & 3.6 & 1.2 \\
\hline External & 1.5 & 2.6 & -1.8 & 2.2 & 5.0 & 2.7 & 4.4 & 2.3 \\
\hline Domestic (net) & -2.5 & -2.8 & 1.4 & $-2,0$ & -1.7 & -0.8 & 0.1 & 6.0 \\
\hline Privatization & 0.6 & 0.0 & 0.9 & 7.8 & 2.9 & 2.5 & 3.4 & 4.4 \\
\hline Trust fund for development & 0.0 & 0.0 & -1.0 & -7.8 & -3.1 & -29 & -3.8 & -0.3 \\
\hline External interest obligations & 4.6 & 5.0 & 2.9 & 3.2 & 3.2 & 3.9 & 2.0 & 4.2 \\
\hline \multicolumn{9}{|c|}{ (In millions of balboas) } \\
\hline \multicolumn{9}{|l|}{ Memorandum items: } \\
\hline External interest obligations & 402.3 & 393.0 & 241.6 & 281.6 & 303.2 & 368.0 & 146.5 & 311.3 \\
\hline GDP (market prices) & $7,733.9$ & $3,906.1$ & $8,151.1$ & $8,657.5$ & $9,143.8$ & $9,545.4$ & $7,203.0$ & $7,433.0$ \\
\hline Balance in Thist Fund for Development 4 & 0.0 & 00 & 78.0 & 754,1 & 1,0389 & $1,318.5$ & 1.303 .0 & $1,338.8$ \\
\hline
\end{tabular}

Sources: Office of the Comptrolier General; Ministry of Economy and Finance; and Fund staff estimates.

1/ Current revenue less cursent expendinirt.

2/ Revenue and grants, less expendirure.

3/ Part-year percentages ate artidualized.

4/ The Trust Fund for Development invests divestment proceeds abroad and transfers its javestment income to the central govemment to înance development projects, includits social projects. 
Table 20. Panama: Central Government Operations

\begin{tabular}{|c|c|c|c|c|c|c|c|c|}
\hline & \multirow[b]{2}{*}{1994} & \multirow[b]{2}{*}{1995} & \multirow[b]{2}{*}{1996} & \multirow[b]{2}{*}{1997} & \multirow[b]{2}{*}{1998} & \multirow[b]{2}{*}{1999} & \multicolumn{2}{|c|}{$\begin{array}{c}\text { Preliminary } \\
\text { January - September }\end{array}$} \\
\hline & & & & & & & 1999 & 2000 \\
\hline \multicolumn{9}{|c|}{ (In millions of balboas) } \\
\hline Revenue & 1.361 .9 & $1,473.7$ & $1,544,6$ & $1,600,4$ & $1,710,0$ & $1,940,4$ & $1,371.5$ & $1,392.5$ \\
\hline Tax revenue & 916.3 & 990.2 & 984.9 & $1,043.5$ & $1,104.1$ & 1.211 .2 & 873.5 & 834.7 \\
\hline Income tax & 352.4 & 405.4 & 392.4 & 416,9 & 399.5 & 508.4 & 354.8 & 362.7 \\
\hline Wealth taxes & 41.4 & 43.6 & 45.4 & 47.1 & 51.7 & 59.6 & 41.8 & 40.9 \\
\hline Taxes on foreign trade & 177.7 & 188.3 & 193.6 & 219.0 & 251.4 & 240.1 & 167.9 & 146.5 \\
\hline Taxes on demestic transactions & 344.8 & 352.9 & 353.5 & 360.5 & 401.3 & 403.0 & 309.0 & 284.5 \\
\hline Nontax sevenue & 442.7 & 481.6 & 558.2 & 554.3 & 603.9 & 726.0 & 494.9 & 562.8 \\
\hline Panama Canal & 81.2 & 92.0 & 94.1 & 95.4 & 96.3 & 138.8 & 86.3 & 104.5 \\
\hline Oil pipeline royalties & 3.0 & 3.1 & 0.0 & 0.0 & 0.0 & 0.0 & 0.0 & 0.0 \\
\hline Transfers from the sest of public sector & 220.9 & 264.4 & 345.9 & 257.6 & 223.] & 154.5 & 113.2 & 154,0 \\
\hline Other & 140.6 & 122.1 & 118.2 & 2013 & 284.5 & 432.7 & 295.4 & 304.1 \\
\hline Copitai revenue & 2.9 & 1.9 & 1.5 & 2.5 & 2.0 & 3.2 & 3.1 & 1.0 \\
\hline Grants & 1.0 & 7.8 & 4.6 & 70.6 & 57.3 & 5.0 & 0.0 & 2.1 \\
\hline Expenditure & $1,599.3$ & $1,627,4$ & $1,487.2$ & $1,667,5$ & $2,228.5$ & $2,173.1$ & $1,744.3$ & $1,693.7$ \\
\hline Current & $1, \mathbf{4 2 7 . 7}$ & $1,474.0$ & $1,327.1$ & $1,480.5$ & $1,797.9$ & $1,828.1$ & $1,353.9$ & $1,489,6$ \\
\hline Wages and salaries & 533.0 & 542.9 & 368.5 & 592.4 & 636.8 & 630.0 & 465.1 & 469,4 \\
\hline Severance payments & 0.0 & 0.0 & 0.0 & 0.0 & C. 0 & 55.0 & 0.0 & 0.0 \\
\hline Goods and Services & 134.1 & 111.8 & 112.5 & 147.5 & 144.3 & 163.2 & 128.5 & 139.9 \\
\hline Pensions and transfers & 405.6 & 417.2 & 385.7 & 394.1 & 648.1 & 485.1 & 372.9 & 449.5 \\
\hline \multicolumn{9}{|l|}{ Orwhich: } \\
\hline Social securrity agency & 212.2 & 216.7 & 170.7 & 194.0 & 4000 & 260.1 & 308.7 & 278.4 \\
\hline Decentralized agencies & 68.8 & 68.9 & 74.5 & 76.6 & 78.4 & 83.5 & 63.2 & 65.7 \\
\hline Public enterprises & 0.0 & 2.8 & 2.2 & 2.6 & 20 & 2.1 & 1.0 & 1.5 \\
\hline Interest & 350.3 & 394.4 & 251.4 & 299.7 & 321.9 & 447.3 & $3 \$ 1.0$ & 392.9 \\
\hline Internal & 24.2 & 25.3 & 28.6 & 32.9 & 42.4 & 83.2 & 57.3 & 88.4 \\
\hline External & 326.1 & 369.1 & 222.8 & 266.8 & 279.5 & 364.1 & 293.7 & 304.5 \\
\hline Other surrent expenditure & 4.8 & 7.7 & 8.9 & 46.9 & 46.8 & 47.5 & 36.4 & 37.9 \\
\hline Capital & 171.6 & 153.4 & 160.1 & 187,0 & 430.6 & 345.0 & 390.4 & 204.1 \\
\hline Fjxed mpital formation & 115.6 & 113.6 & 117.8 & 124.2 & 381.7 & 309.3 & 358.3 & 155.9 \\
\hline Transfers of cappilal & 56.0 & 39.8 & 42.3 & $\$ 5.1$ & 29.2 & 35.7 & 32.1 & 38.2 \\
\hline To decentralized agencies & 7.9 & 10.8 & 6.4 & 2.4 & 3.5 & 2.3 & 0.1 & 1.8 \\
\hline To public enterprises & 18.8 & 0.1 & 1.9 & 5.5 & 0.2 & $\ldots$ & 0.0 & $\ldots$ \\
\hline Other & 29.3 & 28.9 & 34.0 & 47.2 & 25.5 & 33.6 & 32.0 & 36.4 \\
\hline On lending & 0.0 & 0.0 & 48.0 & -30.0 & 0.0 & 0.0 & 0.0 & 0.0 \\
\hline Saving $1 /$ & -68.7 & -2.2 & 2160 & 117.4 & -89.9 & 109.1 & 14.5 & -92.1 \\
\hline Overall balance (deffclt-) 2 & -236.4 & -145.9 & $\mathbf{3 4 . 0}$ & -4.2 & -461.4 & -227.7 & $-\mathbf{3 7 2 . 8}$ & -293.1 \\
\hline
\end{tabular}


Table 20. Panama: Central Government Operations (Concluded)

\begin{tabular}{|c|c|c|c|c|c|c|c|c|}
\hline & \multirow[b]{2}{*}{1994} & \multirow[b]{2}{*}{1995} & \multirow[b]{2}{*}{1996} & \multirow[b]{2}{*}{1997} & \multirow[b]{2}{*}{2998} & \multirow[b]{2}{*}{1999} & \multicolumn{2}{|c|}{$\begin{array}{c}\text { Preliminary } \\
\text { January - September }\end{array}$} \\
\hline & & & & & & & 1,999 & 2000 \\
\hline \multicolumn{9}{|c|}{ (In millions of balboas) } \\
\hline Flnancing & 236.4 & 145.9 & -14.0 & 4.2 & 461.4 & 227.7 & 372.8 & 293.1 \\
\hline External & 147.0 & 269.8 & -96.9 & 240.1 & 471.8 & 264.1 & 295.7 & 177,7 \\
\hline Disbutsements & 58.0 & 99.5 & 250.6 & $1,483.1$ & 655.0 & 625.3 & 603.2 & 448.1 \\
\hline Repayments & 198.0 & 196.0 & 274.6 & $1,195.9$ & 231.1 & 393.0 & 336.6 & 318.6 \\
\hline Debt tescheduling & 481.0 & 29.9 & $3,342.8$ & 35.7 & 19.2 & 31.8 & 29.1 & 24.6 \\
\hline Arrears & -144.0 & 336.4 & $-3,415.7$ & -67.8 & 0.0 & 0.0 & 0.0 & 0.0 \\
\hline Change in depesits abroad & & 0.0 & 0.0 & -15.0 & 38.7 & 0,0 & 0.0 & 23.7 \\
\hline Domestic (net) & 39.4 & -123.9 & 88.3 & -235.9 & -10.5 & -36.4 & -164.3 & 115.4 \\
\hline Of which: & & & & & & & & \\
\hline Banking system & -12.6 & -55.9 & 222.0 & -132.3 & -159.2 & 106.2 & 23.6 & -16.7 \\
\hline Arrears & 35.0 & 0.0 & 0.0 & 0.0 & 0.0 & 0.0 & 0.0 & 0.0 \\
\hline Privatization & 50.0 & 0.0 & 72.6 & 671.6 & 260.5 & 241.4 & 241.4 & 1.1 \\
\hline Trust Fund for Development & 0.0 & 0.0 & -78.0 & -671.6 & -260.5 & -241.4 & -241.4 & -1.1 \\
\hline \multicolumn{9}{|c|}{ (Anmulal percent change) } \\
\hline Current revenue & 0.4 & 8.2 & 4.8 & 3.6 & 6.8 & 13.4 & 13.3 & 2.1 \\
\hline Tax revenule & 6.2 & 8.1 & -0.5 & 5.9 & 5.8 & 9.7 & 6.9 & $-4,4$ \\
\hline Nontax teqetuse & -9.9 & 8.8 & 15.9 & -0.7 & 8.9 & 20.2 & 26.7 & 13.7 \\
\hline Total expenditure & -0.5 & 1.8 & $-8,6$ & 12.1 & 33.6 & -2.5 & $-2,4$ & -2.9 \\
\hline Current expenditure & 1.9 & 3.2 & -10.0 & 11.6 & 21.4 & 1.7 & -2.9 & 10.0 \\
\hline Capital expenditure & -16.5 & -10.6 & 4.4 & 16.8 & 130.3 & -19.9 & -0.7 & -47.7 \\
\hline \multicolumn{9}{|c|}{ (In percent of GDP 3/) } \\
\hline Current revenue & 17.6 & 18.6 & 18.9 & 18.5 & 18.7 & 20.3 & 19.0 & 18.8 \\
\hline Tax repenue & 11.8 & 12.5 & 12.1 & 12.1 & 12.1 & 12.7 & 12.1 & 11.2 \\
\hline Nontax revenue & 5.7 & 6.1 & 6.8 & 6.4 & 6.6 & 7.6 & 6.9 & 7.6 \\
\hline Total expenditure & 20.7 & 20.6 & 18.2 & 19.3 & 24.4 & 22.8 & 24.2 & 22.8 \\
\hline Current expenditure & 18.5 & 18.6 & 16.3 & 17.1 & 19.7 & 19.2 & 18.8 & 20.0 \\
\hline Capital expenditare & 2.2 & 1.9 & 2.0 & 2.2 & 4.7 & 3.6 & 5.4 & 2.7 \\
\hline Saving $1 /$ & -0.9 & 0.0 & 2.6 & 1.4 & -1.0 & 1.1 & 0.2 & -1.2 \\
\hline Overall batsuce (deficit-) 2 / & -3.1 & -1.8 & 0.2 & D.0 & $-8,0$ & -2.4 & -5.2 & -3.9 \\
\hline Finanche (net) & 3.1 & 1.8 & -0.2 & 0.0 & 5.0 & 2.4 & 5.2 & 3.9 \\
\hline Extemal & 1.9 & 3.4 & -1.2 & 28 & 5.2 & 2.8 & 4.1 & 2.4 \\
\hline Domestic & 0.5 & -1.6 & 1.1 & -2.8 & .0 .1 & $-\mathbf{0 . 4}$ & -2.3 & 1.6 \\
\hline Privatization & 0.6 & 0.0 & 0.9 & 7.8 & 2.8 & 2.5 & 3.4 & 0.0 \\
\hline Trust Fund for Development & 0.0 & 0.0 & -1.0 & .7 .8 & -2.8 & -2.5 & -3.4 & $\mathbf{0 . 0}$ \\
\hline \multicolumn{9}{|c|}{ (In millions of balboas) } \\
\hline \multicolumn{9}{|l|}{ Memorandum htems: } \\
\hline GDP (market prices) & $7,733.9$ & 7906.1 & $8,15 \mathrm{~L} .1$ & $8,657.5$ & $9,143.8$ & $9,545.4$ & $7,203,0$ & $7,433.0$ \\
\hline Balance in Trust Fund for Developenent 4 & 0.0 & 0.0 & 78.0 & 754.2 & $5,038.9$ & $1,3] 8.5$ & $1,303.0$ & $1,338.8$ \\
\hline
\end{tabular}

Sources: Office of the Comptroller General; Miristry of Economy and Finance; and Fund staff estimates.

1/ Current revemue less current expendifure.

2 Revenue and grants, less expenditure.

3/ Part-year percentages are anmulized.

4/ The Tnist Fund for Development invests divestment proceds abroad and transfers its investrnent income to the central government to finane cevelopment projects, including social projects. 
Table 21. Panama: Central Government Revenue

\begin{tabular}{|c|c|c|c|c|c|c|c|c|}
\hline & \multirow[b]{2}{*}{2994} & \multirow[b]{2}{*}{1999} & \multirow[b]{2}{*}{1996} & \multirow[b]{2}{*}{1997} & \multirow[b]{2}{*}{1998} & \multirow[b]{2}{*}{1999} & \multicolumn{2}{|c|}{$\begin{array}{c}\text { Preliminary } \\
\text { January - September }\end{array}$} \\
\hline & & & & & & & 1999 & 2000 \\
\hline \multicolumn{9}{|c|}{ (In millions of balboas) } \\
\hline Total revenue (includins grants) & $1,362.9$ & $1,481.5$ & $1,549.2$ & $1,670.9$ & $1,767,3$ & $1,945,4$ & 1,3715 & $1,400.4$ \\
\hline $\begin{array}{l}\text { Tax revemue } \\
\text { Direct taxes }\end{array}$ & $\begin{array}{l}916.3 \\
393.8\end{array}$ & $\begin{array}{l}990.2 \\
449.0\end{array}$ & $\begin{array}{l}994.9 \\
437.8\end{array}$ & $\begin{array}{r}1,043.5 \\
464.0\end{array}$ & $\begin{array}{r}1,104.1 \\
451.2\end{array}$ & $\begin{array}{r}1,211.2 \\
568.0\end{array}$ & $\begin{array}{l}873.5 \\
396.6\end{array}$ & $\begin{array}{l}834.5 \\
403.6\end{array}$ \\
\hline Income tax & 352.4 & 405.4 & 392.4 & 4169 & 399.5 & 508.4 & 354.8 & 362.7 \\
\hline Wealth tax & 41.4 & 43.6 & 45.4 & $47 . \pm$ & 51.7 & 59.6 & 41.8 & 40,9 \\
\hline Taxes on forcign trade & 177.7 & 188.3 & 193.6 & 219.0 & 251.4 & 240.2 & 167.6 & 146.5 \\
\hline Export taxes & 13.6 & 10.7 & 9.4 & 6.2 & 2.9 & 0.6 & 0.5 & 0.1 \\
\hline Import takes & 164.1 & 177.6 & 184.2 & 212.8 & 248.5 & 239.6 & 167.1 & 146.4 \\
\hline Taxes on domestic transactions & 344.8 & 352.9 & 353.5 & 360.5 & 401.3 & 403.0 & 309.0 & 284.4 \\
\hline Tobacco and beverages & 40.8 & 41.4 & 37.1 & 40.2 & 38.0 & 33.4 & 25.0 & 26.8 \\
\hline Value soded tax & 143.2 & 147.3 & 154.6 & 163.5 & 182.5 & 187.5 & 140.7 & 124.3 \\
\hline Petroloum produots & 93.9 & 95.3 & 97.6 & 93.9 & $1 \pm 5.2$ & 122.0 & 93.4 & 80.3 \\
\hline stamp taxes & 36.3 & 37.6 & 33.6 & 373 & 38.4 & & 28.1 & \\
\hline Other & 30.6 & 31.2 & 30.7 & 25.6 & 27.2 & 60.1 & 21.8 & 53.0 \\
\hline $\begin{array}{l}\text { Nontas revenue } \\
\text { Panamed Canal }\end{array}$ & $\begin{array}{r}442.7 \\
81.2\end{array}$ & $\begin{array}{r}481.6 \\
93.0\end{array}$ & $\begin{array}{r}558.2 \\
94.1\end{array}$ & $\begin{array}{r}554.3 \\
95.4\end{array}$ & $\begin{array}{r}603.8 \\
96.3\end{array}$ & $\begin{array}{l}726.0 \\
138.8\end{array}$ & $\begin{array}{r}494.9 \\
86.3\end{array}$ & $\begin{array}{l}562.8 \\
104.5\end{array}$ \\
\hline Oil pipeline royalties & 3.0 & 3.1 & 0.0 & 0.0 & 0.0 & 0.0 & 0.0 & 0.0 \\
\hline Other Services & 137.6 & 122.1 & 118.2 & 181.0 & 212.3 & 194.7 & 154,5 & 116.6 \\
\hline $\begin{array}{l}\text { Transfers from test of publie sector } \\
\text { Of which: }\end{array}$ & 220.9 & 264.4 & 345,9 & 257.6 & 223.1 & 154.5 & 113.2 & 154.0 \\
\hline Consolidated public sector & 154.7 & 184.7 & 217.2 & 150.4 & 125.9 & 58.9 & 50.3 & $\$ 5.8$ \\
\hline Nonconsolidated public sector & 11.6 & 13.6 & 64.3 & 10.7 .2 & 97.2 & 95.5 & 62.9 & 98.2 \\
\hline Interest earnings and dividends & 0.0 & 0.0 & 0.0 & 20.3 & 72.1 & 238.0 & 141.0 & 187.7 \\
\hline Capital revenue & 2.9 & 1.9 & 1.5 & 2.5 & 2.0 & 3.2 & 3.1 & 1.0 \\
\hline Grants & 1.0 & 7.8 & 4.6 & 70.6 & 57.3 & 5.0 & 0.0 & 2.1 \\
\hline \multicolumn{9}{|c|}{ (In percent of GDP 1 ) } \\
\hline Total revenue & 17.6 & 18.7 & 19.0 & 19.3 & 19.3 & 20.4 & 19.0 & 18.8 \\
\hline Tax revenue & 11.8 & 12.5 & 12.1 & 12.1 & 12.1 & 12.7 & 12.1 & 11.2 \\
\hline Direct taxes & 5.1 & 5.7 & 5.4 & 5.4 & 4.9 & 6.0 & 5.5 & 5.4 \\
\hline Income tax & 4.6 & $\$ .1$ & 4.8 & 4.8 & 4.4 & 53 & 4.9 & 49 \\
\hline Woalth tax. & 0.5 & 0.6 & 0.6 & 0.5 & 0.6 & 0.6 & 0.6 & 0.6 \\
\hline Taxes on foreiga trade & 2.3 & 2.4 & 2,4 & 2.5 & 2.7 & 2.5 & 2.3 & 2.10 \\
\hline Export caxes & 0.2 & 0.1 & 0.1 & 0.1 & 0.0 & 0.0 & 0.0 & 0.0 \\
\hline Inport taxes & 2.1 & 2.2 & 2.3 & 2.5 & 2.7 & 2.5 & 2.3 & 2.0 \\
\hline Taxes on domestic transactions & 4.5 & 4.5 & 4.3 & 4.2 & 4.4 & 4.2 & 4.3 & 3.8 \\
\hline Tobacoo and beverages & 0.5 & 0.5 & 0.5 & 0.5 & 0.4 & 0.3 & 0.3 & 0.4 \\
\hline Value added tax & 1.9 & 1.9 & 1.9 & 1.9 & 2.3 & 2.0 & 2.0 & 1.7 \\
\hline Petroleum products & 1.2 & 1.2 & 1.2 & 1.1 & 1.3 & 1.3 & 1.3 & 1.1 \\
\hline Stathp taxes & 0.5 & 0.5 & 0.4 & 0.4 & 0.4 & 0.0 & 0.4 & 0.0 \\
\hline Other & 0.4 & 0.4 & 0.4 & 0.3 & 0.3 & 0.6 & 0.3 & 0.7 \\
\hline Nontas revenue & 5.7 & 6.1 & 6.8 & 6.4 & 6.6 & 1.5 & 6.9 & 7,6 \\
\hline Panama Cansil & 1.0 & 1.2 & 1.2 & 1.1 & 1.1 & 0.0 & 1.2 & 1.4 \\
\hline Oil pipeline royalties & 0.0 & 0.0 & 0.0 & 0.0 & 0.0 & 2.0 & 0.0 & 0.0 \\
\hline Services & 1.8 & 1.5 & 1.5 & 2.1 & 2.3 & 1.6 & 2.1 & 1.6 \\
\hline $\begin{array}{l}\text { Transfers from rest of publie sector } \\
\text { Of whroh: }\end{array}$ & 2.9 & 3.3 & 4.2 & 3.0 & 2.4 & 0.0 & 1.6 & 2.1 \\
\hline Consolidated publio sector & 2.0 & 2.3 & 2.7 & 1.7 & 1.4 & 1.D & 0.7 & 0.8 \\
\hline Noncansolidated public sector & 0.1 & 0.2 & 0.8 & 1.2 & 1.1 & 2.5 & 0.9 & 1.3 \\
\hline Interest eamings and dividends & 0.0 & 0.0 & 0.0 & 0.2 & 0.8 & 0.0 & 2.0 & 2.5 \\
\hline Capital revenue & 0.0 & 0.0 & 0.0 & 0.0 & 0.0 & 0.0 & 0.0 & 0,0 \\
\hline Grants & 0.0 & a.1 & 0,1 & 0.8 & 0.6 & 0.0 & 0.0 & 0.0 \\
\hline
\end{tabular}

Sourpes: Offipe of the Comptroller General; Miristry of Economy and Finance; and Fund staff estimates.

1/ Part-year percentages are arnualized. 
Table 22. Panama: Central Government Expenditure

\begin{tabular}{|c|c|c|c|c|c|c|c|c|}
\hline & \multirow[b]{2}{*}{1994} & \multirow[b]{2}{*}{1995} & \multirow[b]{2}{*}{1996} & \multirow[b]{2}{*}{1997} & \multirow[b]{2}{*}{1998} & \multirow[b]{2}{*}{1999} & \multicolumn{2}{|c|}{$\begin{array}{c}\text { Preliminary } \\
\text { Jenuary - Soptemiber }\end{array}$} \\
\hline & & & & & & & 1999 & 2000 \\
\hline \multicolumn{9}{|c|}{ (In percent of GDP II) } \\
\hline Total expenditure $2 /$ & 20.7 & 20.2 & 19.6 & 18.5 & 17.5 & 22.8 & 24.2 & 22.8 \\
\hline Current expenditure & 18.5 & 186 & 16.3 & 17.1 & 19.7 & 19.2 & 18.8 & 20.0 \\
\hline Wages and selaries & 6.9 & 6.9 & 7.0 & 6.8 & 7.0 & 6.6 & 6.5 & 6.3 \\
\hline Goods and services & 1.7 & 1.4 & 1.4 & 1.7 & 1.6 & 1.7 & 1.8 & 1.9 \\
\hline Interest & 4.5 & 5.0 & 3.1 & 3.5 & 3.5 & 4.7 & 4.9 & 5.3 \\
\hline Pensions and transfers & 5.2 & 5.3 & 4.7 & 4.6 & 7.1 & 5.1 & 5.2 & 6.0 \\
\hline Other & 0.1 & 0.1 & 0.1 & 0.5 & 0.5 & $\mathbf{0 . 5}$ & 0.5 & 0.5 \\
\hline Capital expenditure & 2.2 & 1.9 & 2.0 & 2.2 & 4.5 & 3.6 & 5,4 & 2.7 \\
\hline Investment & 1.5 & 1.4 & 1.4 & 1.4 & 4.2 & 3.2 & 5.0 & 2.2 \\
\hline Transfers & 0.7 & 0.5 & 0.5 & 0.6 & 0.3 & 0.4 & 0.4 & 0.5 \\
\hline \multicolumn{9}{|l|}{ Memorandum item: } \\
\hline Noninterest expenditure & 16.1 & 15.6 & 15.2 & 15.8 & 20.6 & 18.1 & 19.3 & 17.5 \\
\hline \multicolumn{9}{|c|}{ (Armual percent change) } \\
\hline Total expenditure & -0.5 & 1.8 & -8.6 & 121 & 33.6 & -2.5 & 29.4 & -2.9 \\
\hline Current expenditure & 1.9 & 3.2 & -10.0 & 11.6 & 21.4 & 1.7 & 27,8 & 10.0 \\
\hline Wages and salaries & -6.1 & 1.9 & 4.7 & 4.2 & 7.5 & -1.1 & 9.5 & 0.9 \\
\hline Goods and services & -10.2 & -16.6 & 0.6 & 31.1 & -2.2 & 13.1 & 27.8 & 8.9 \\
\hline Interest & 20.5 & 12.6 & -36.3 & 19.2 & 7.4 & 39.0 & 10.0 & 11.9 \\
\hline Pensions and transfers & 4,3 & 2.9 & -7.5 & 2.2 & 64.5 & -25.2 & 63.5 & 20.5 \\
\hline Other & -4.0 & 60.3 & 15.7 & 427.0 & -0.2 & 1.5 & 10.3 & 4.1 \\
\hline Capital expenditure & -16.5 & -10.6 & 4.4 & 16.8 & 130.3 & -19.9 & 38.4 & -47.7 \\
\hline Investment & -28.8 & -1.7 & 3.7 & 12.0 & 189.4 & -19.0 & 44.3 & -53.7 \\
\hline Transfers & 30.2 & -28.9 & 6.3 & 30.3 & -47.0 & 22.3 & 18.2 & 19.0 \\
\hline \multicolumn{9}{|l|}{ Memorandum item: } \\
\hline Noninterest expenditure & -5.1 & -5.1 & -5.1 & -5.1 & -5.1 & -9.5 & 33.1 & -6.6 \\
\hline
\end{tabular}

Sources: Office of the Comptroller General; Ministry of Economy and Finance; and Fund staff estimates.

1/ Part-year percentages are annualized.

2/ Does not include onlending. 
Table 23. Panama: Operations of the Social Security Agency

\begin{tabular}{|c|c|c|c|c|c|c|c|c|}
\hline & \multirow[b]{2}{*}{1994} & \multirow[b]{2}{*}{1995} & \multirow[b]{2}{*}{1996} & \multirow[b]{2}{*}{1997} & \multirow[b]{2}{*}{1998} & \multirow[b]{2}{*}{1999} & \multicolumn{2}{|c|}{$\begin{array}{c}\text { Preliminary } \\
\text { January - September }\end{array}$} \\
\hline & & & & & & & 1999 & 2000 \\
\hline \multicolumn{9}{|c|}{ (In millions of balboas) } \\
\hline Current revenue & 522.3 & 586.5 & 613.5 & 613.0 & 666.8 & 689.9 & 527.6 & 576.5 \\
\hline Contributions & 396.3 & 452.6 & 475.0 & 488.8 & 522.9 & 556.9 & 427.9 & 457.3 \\
\hline Professional risk premiun & 35.0 & 40.5 & 38.5 & 36.8 & 40.6 & 44.3 & 33.4 & 35.6 \\
\hline Administered funds & 18.0 & 29.1 & 24.3 & 11.9 & 6.9 & 6.7 & 4.8 & 3.9 \\
\hline Income from investment & 39.0 & 53.8 & 59.5 & 58.5 & 64.3 & 63.4 & 46.5 & 55.6 \\
\hline Other & 34.0 & 10.5 & 16.2 & 17.0 & 32.1 & 18.6 & 15.0 & 24.1 \\
\hline Current expenditure & 651.8 & 720.2 & 725.5 & 780.6 & 815.2 & 846.0 & 624.6 & 674.7 \\
\hline Wages & {$[34.3$} & 143.3 & 151.4 & 156.2 & 166.0 & 171.6 & 127.6 & 132.4 \\
\hline Goods and services & 82.2 & 107.3 & 90.6 & 97.5 & 104.2 & 111.8 & 79.3 & 81.1 \\
\hline Transfers & 435.3 & 468.6 & 482.6 & 526.2 & $\$ 44.4$ & $\$ 62.0$ & 417.3 & 460.9 \\
\hline Domestic interest & 0.0 & 0.9 & 1.0 & 0.7 & 0.6 & 0.5 & 0.4 & 0.3 \\
\hline Operating balance (deficit -) & -129.5 & -133.7 & -112.0 & -167.6 & -148.4 & -156.1 & -97.0 & $-98,2$ \\
\hline Current transfers (net) & 211.7 & 216.7 & 170.7 & 193.5 & 399.5 & 259.6 & 203.3 & 278 \\
\hline Transfers from central government & 212.2 & 216.7 & 170.7 & 194.0 & 400.0 & 260.1 & 203.6 & 278.4 \\
\hline Transfers to central government & 0.5 & 0.0 & 0.0 & 0.5 & 0.5 & 0.5 & 0.3 & 0.4 \\
\hline Capital revenue & 10.8 & 11.4 & 12.2 & 9.7 & 10.5 & 11.7 & 8.8 & 11.1 \\
\hline Saring 11 & 93.0 & 94.4 & 70.9 & 35.6 & 261.6 & 115.2 & 115.1 & 190.9 \\
\hline Capitsl expenditure & 7.8 & 20.2 & 37.1 & 24.2 & 27.0 & 27.2 & 22.0 & 16.5 \\
\hline Fixed investment & 7.8 & 11.6 & 20.2 & 24.2 & 27.0 & 27.2 & 22.0 & 16.5 \\
\hline Financial investment & 0.0 & 8.6 & 16.9 & 0.0 & 0.0 & 0.0 & 0.0 & 0 \\
\hline Overall balance (deficit -) & 85.2 & 74.2 & 33.8 & 11.4 & 234.6 & 88.0 & 93.1 & \pm 74.4 \\
\hline \multicolumn{9}{|c|}{ (In percent of GDP 2h) } \\
\hline $\begin{array}{l}\text { Current revenue } \\
\text { Of which: }\end{array}$ & 6.8 & 7.4 & 7.5 & 7.1 & 7.3 & 7.2 & 7.3 & 7.8 \\
\hline Coniributions & 5.1 & 5.7 & 5.8 & 5.6 & 5.7 & 5.8 & 5.9 & 6.2 \\
\hline $\begin{array}{l}\text { Total expenditure } \\
\text { of which: }\end{array}$ & 8.5 & 9.4 & 9.4 & 9.3 & 9.2 & 9.1 & 9.0 & 9.3 \\
\hline Carrent & 8.4 & 9.1 & 8.9 & 9.0 & 8.9 & 8.9 & 8.7 & 9.1 \\
\hline Operating balance (deficit -) & -1.7 & -1.7 & -1.4 & -1.9 & -1.6 & -1.6 & -1.3 & -1.3 \\
\hline Current transfers (net) & 2.7 & 2.7 & 2.1 & 2.2 & 4.4 & 2.7 & 2.8 & 3.7 \\
\hline Overall balance (deficit -) & 1.1 & 0.9 & 0.4 & 0.1 & 2.6 & 0.9 & 1.3 & 2.3 \\
\hline
\end{tabular}

Sources: Social Security Agency, Miristry of Economy and Finance; and Fund staff estimates.

1/ Ineluding capital revenue.

2/ Part-year percentages are annualized. 
Table 24. Panama: Operations of the Decentralized Agencies 1/

\begin{tabular}{|c|c|c|c|c|c|c|c|c|}
\hline & \multirow[b]{2}{*}{1994} & \multirow[b]{2}{*}{1995} & \multirow[b]{2}{*}{1996} & \multirow[b]{2}{*}{1997} & \multirow[b]{2}{*}{1998} & \multirow[b]{2}{*}{1599} & \multicolumn{2}{|c|}{$\begin{array}{c}\text { Preliminary } \\
\text { Janutary - September } \\
\end{array}$} \\
\hline & & & & & & & 1999 & 2000 \\
\hline \multicolumn{9}{|c|}{ (In millions of balboss) } \\
\hline Operating revenue & 55.7 & 52.7 & 58.4 & $\$ 7.9$ & 70.4 & 77.2 & 56.8 & 60.1 \\
\hline Operating expendituse & 113.3 & 116.7 & 123.5 & 135.7 & 143.7 & 140.4 & 105.4 & 106.6 \\
\hline Interest & 7.3 & 6.7 & 6.2 & 6.7 & 9.0 & 3.6 & 4.6 & 4.8 \\
\hline Other & 106.0 & 110.0 & 117.4 & 129.0 & 134.7 & 136.8 & 100.8 & 101.8 \\
\hline Operating balance (deficit-) & -57.6 & -56.9 & -65.1 & -77.8 & -73.3 & -63.2 & -48.6 & -46.5 \\
\hline Current transfers (net) & 68.7 & 68.9 & 70.0 & 76.6 & 74.4 & 83.3 & 63.1 & 65.5 \\
\hline Transfers from central government & 68.8 & 68.9 & 74,5 & 76.6 & 78.4 & 83.5 & 63.2 & 65.7 \\
\hline Transfers to centrial government & 0.1 & 0.0 & 4.6 & 0.0 & 4.0 & 0.2 & 0.1 & 0.2 \\
\hline Transfers from public enterprises $2 l$ & -0.1 & 0.0 & -9.1 & 0.0 & 0.0 & 0.0 & 0.0 & 0.0 \\
\hline Capital transfers from central govertmment & 7.9 & 10.8 & 64 & 2.4 & 3.3 & 2.1 & 2.0 & 1.1 \\
\hline Capital revenue & 3.4 & 2.5 & 1.7 & 10.8 & 15.1 & 25.5 & 13.8 & 12.1 \\
\hline Saving $3 i$ & 14.5 & 14.5 & 6.5 & 9.6 & 16.2 & 45.6 & 28.3 & 31.1 \\
\hline Capltal expenditure & 9.6 & 11.5 & 20.3 & $\mathbf{2 3 . 0}$ & 24.5 & 19.0 & 13.4 & 16.7 \\
\hline Fixed investment & 19.6 & 13.6 & 15.6 & 23.0 & 24.5 & 19.0 & 13.4 & 16.7 \\
\hline Net lending & -10.0 & -3.1 & 4.7 & 0.0 & 0.0 & 0.0 & 0.0 & 0.0 \\
\hline Overall balance (deficit -) & 12.8 & 13.8 & -7.3 & .11 .0 & -5.0 & 28.7 & 16.9 & 15.5 \\
\hline \multicolumn{9}{|c|}{ (in percent of GDP) $4 /$} \\
\hline Operating revenue & 0.7 & 0.8 & 0.7 & 0.7 & 0.8 & 0.8 & 0.8 & 0.8 \\
\hline Operating expenditure & 1.5 & 1,5 & 1.5 & 1.6 & 1.6 & 1.5 & 1.5 & 1.4 \\
\hline Operating balance (deficit -) & -0.7 & -0.7 & -0.8 & 40.9 & -0.8 & -0.7 & -0.7 & -0.6 \\
\hline Current transfers (net) & 0.9 & 0.9 & 0.9 & 0.9 & 0.8 & 0.9 & 0.9 & 0.9 \\
\hline Overall bajance (deficit -) & 0.2 & 0.2 & -0.1 & -0.1 & .0 .1 & 0.3 & 0.2 & 0.2 \\
\hline
\end{tabular}

Sources: Office of the Comptroller General; Ministry of Economy and Finance; and Fund staff estimates.

1/ Includes the operations of the University of Puname Human Development Institute (IFARHU) Agricultural Development Bank (BDA), Agricultural Marketing Institute (DMA), and Nationsl Mortgage Bank (BHN).

$2 /$ Transfers recejved to finance vocational training.

3/ Incliding capital revenue.

4/ Part-year percentages are annuslized. 
Table 25. Panama: Operations of the Public Enterprises 1/

\begin{tabular}{|c|c|c|c|c|c|c|c|c|}
\hline & \multirow[b]{2}{*}{1994} & \multirow[b]{2}{*}{1995} & \multirow[b]{2}{*}{1996} & \multirow[b]{2}{*}{1997} & \multirow[b]{2}{*}{1998} & \multirow[b]{2}{*}{1999} & \multicolumn{2}{|c|}{$\begin{array}{c}\text { Preliminary } \\
\text { January - September }\end{array}$} \\
\hline & & & & & & & 1999 & 2000 \\
\hline \multicolumn{9}{|c|}{ (In millions of balboas) } \\
\hline Current revenut & 754.3 & 779.0 & 740.6 & 637.6 & 498.8 & 266.2 & 180.3 & 181.3 \\
\hline Operating expesditure & 385.0 & 408.4 & 447.2 & 397.2 & 369.6 & 142.7 & 102.2 & 120.7 \\
\hline Wages and salaries & 149.1 & 169.4 & 174.3 & 122.5 & 95.9 & 45.8 & 33.4 & 33.5 \\
\hline Goods and services & 158.7 & 164.2 & 152.3 & 127.7 & 174.5 & 58.9 & 41.8 & 42 \\
\hline Transfers & 33.5 & 34.3 & 73.1 & 60.6 & 25.4 & 16.6 & 13.2 & 19.3 \\
\hline Other & 14.7 & 15.6 & 27.8 & 59.1 & 50.2 & 11.3 & 6.5 & 22 \\
\hline Interest & 29.0 & 24.9 & 19.6 & 27.3 & 23.6 & 10.1 & 7.3 & 3.9 \\
\hline Domestic & 1.1 & 1.0 & 0.8 & 12.5 & 7.7 & 2.7 & 3.4 & 3.9 \\
\hline External & 27.9 & 23.9 & 18.8 & 14.8 & 15.9 & 7.4 & 3.9 & $\ldots$ \\
\hline Operating balance (deficlt - ) & 369.3 & 370.6 & 293.4 & 248.4 & 129.2 & 123.5 & 781 & 60.6 \\
\hline Current transfers net of tayes & -154.1 & -181.9 & -210.4 & -147.3 & -119.4 & -56.1 & -48.9 & $\mathbf{- 5 3 . 7}$ \\
\hline Transfers from central government & 0.0 & 2.8 & 2.2 & 2.6 & 2.0 & 2.1 & 1.0 & 1.5 \\
\hline Transfers to central governument & -154.1 & -184.7 & -212.6 & -149.9 & -121.4 & -58.2 & -49.9 & -55.2 \\
\hline Transfers to rost of public sector & 0.0 & 0.0 & 0.0 & 0.0 & 0.0 & 0.0 & 0.0 & 0.0 \\
\hline Capital revenus & 7.2 & 0.0 & 3.3 & 7.0 & 0.0 & 0.0 & 0.0 & 0.0 \\
\hline Capital transfers from entral goveaument & 18.8 & 0.1 & 1.9 & 5.5 & 0.2 & 0.0 & 0,0 & 0.7 \\
\hline Soving $y$ & 222.4 & 188.7 & 86.3 & 100.1 & 9.8 & 67.4 & $\mathbf{2 9 . 2}$ & 6.9 \\
\hline Capital expenditure & 104,6 & 97.8 & 104.3 & 96.2 & 104.7 & 67.9 & 12.8 & 20.5 \\
\hline Net borrowing & 0.0 & 0.0 & 48.0 & -30.0 & 0.0 & 0.0 & 0.0 & 0.0 \\
\hline Overalf balapice (deficit -) & 136.7 & 91.0 & 31.9 & -20.6 & -89.6 & -0.5 & 16.4 & -12.9 \\
\hline \multicolumn{9}{|c|}{ (In percent of GDP $3 /$ ) } \\
\hline Current revenue & 9.8 & 9.9 & 9.1 & 7.4 & 5.5 & 2.8 & 2.5 & 2.4 \\
\hline Operating expenditure & 5.0 & 5.2 & 5.5 & 4.6 & 4.0 & 1.5 & 1.4 & 1.6 \\
\hline Operating balance (deficit -) & 4.8 & 4.7 & 3.6 & 2.8 & 1.5 & 1.3 & 1.1 & 0.8 \\
\hline Current transfers (net) & -2.0 & -2.3 & -2.6 & -1.7 & -1.3 & -0.6 & -0.7 & -0.7 \\
\hline Capital expenditure & 1.4 & 1.2 & 1.3 & 1.1 & 1.1 & 0.7 & 0.2 & 0.3 \\
\hline Overall balance (deficit t) & 1,8 & 1.2 & 0.4 & -0.2 & -1.0 & 0.0 & 0.2 & -0.2 \\
\hline
\end{tabular}

Sources: Office of the Comptroller General; Ministry of Economy and Finance; and Fund staff estimates.

I/ Includes the operations of the Hydraulic Resources and Electricity Institute (IHRE), National Telecommunications Institute (INTEL) (untii May 1997). Colon Free Znne (operating agancy), Civil Aviation Authority, National Water and Sewerage Institute (IDAAN), Ia Victoria Sugar Corporation, Eourism Institute, Bayano Cement Plant (until September 1994), and the Port Authority which on March 1, 1997 privatized about three-quarters of its operations.

2/ Inchuding capital revenuse.

3/ Part-year percentages are annualized. 
Table 26. Panama: Nonfinancial Public Sector Gross Domestic Debt

(In millions of balboas; end of period)

\begin{tabular}{|c|c|c|c|c|c|c|c|c|}
\hline & \multirow[b]{2}{*}{1994} & \multirow[b]{2}{*}{1995} & \multirow[b]{2}{*}{1996} & \multirow[b]{2}{*}{1997} & \multirow[b]{2}{*}{1998} & \multirow[b]{2}{*}{1999} & \multicolumn{2}{|c|}{ September } \\
\hline & & & & & & & 1999 & 2000 \\
\hline $\begin{array}{l}\text { Consolidated nonfinancial } \\
\text { public sector }\end{array}$ & $1,0.03 .5$ & 946.1 & $1,136.6$ & $1,168.3$ & $1,073.5$ & $1,425.7$ & $1,445.4$ & $\ldots$ \\
\hline Loans & 41.8 & 37.0 & 207.0 & 230.2 & 245.8 & 217.2 & 227.7 & $\ldots$ \\
\hline Securities & 961.7 & 909.2 & 929.5 & 938.1 & 827.7 & $1,208.5$ & $1,217.7$ & $\ldots$ \\
\hline Central government & $1,794.7$ & $1,670.7$ & $1,792.2$ & $1,735.6$ & $1,736.0$ & $2,107.4$ & $2,149.8$ & $2,186.7$ \\
\hline Loans & 31.1 & 25.8 & 196.7 & 223.2 & 243.1 & 198.4 & 213.3 & 165.7 \\
\hline Securities & $1,763.6$ & $1,644.9$ & $1,595.5$ & $1,512.4$ & $1,492.9$ & $1,909.0$ & $1,936.5$ & $2,021.0$ \\
\hline
\end{tabular}

Sources: Office of the Comptroller General; and Fund staff estimates. 
Table 27. Panama: Accounts of the Banking System 1/

(In rillions of balboas; end af period)

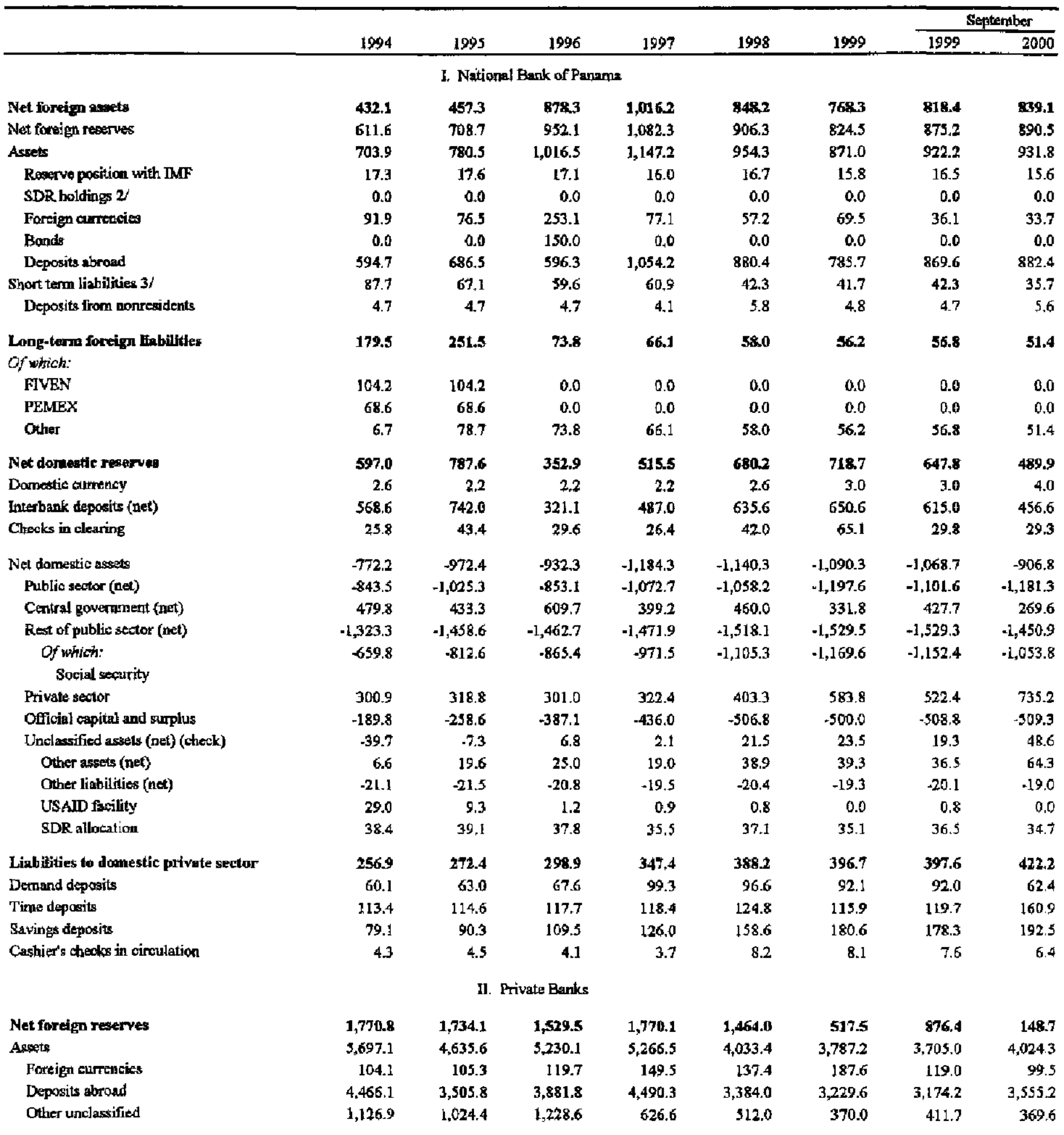


Table 27. Panama: Accounts of the Banking System 1/ (Continued)

(In millions of baiboas: end of period)

\begin{tabular}{|c|c|c|c|c|c|c|c|c|}
\hline & \multirow[b]{2}{*}{1994} & \multirow[b]{2}{*}{1995} & \multirow[b]{2}{*}{1996} & \multirow[b]{2}{*}{1997} & \multirow[b]{2}{*}{1998} & \multirow[b]{2}{*}{1999} & \multicolumn{2}{|c|}{ September } \\
\hline & & & & & & & 1999 & 2000 \\
\hline Liahilitiea & 899.4 & $1,138.3$ & 956.11 & 539.2 & $\$ 23.4$ & 565.9 & 511.5 & 516.0 \\
\hline Overseas operations (net) & $-3,026.9$ & $-1,763.2$ & $-2,744.7$ & $-2,957.2$ & $-2,146.1$ & $-2,703.8$ & $-\mathbf{2 , 3 1 7 . 1}$ & $-3,359.6$ \\
\hline Credit to nonresidents & $10,919.6$ & $11,028.3$ & $10,253.6$ & $11,328.7$ & $9,175.3$ & $8,574.8$ & $8,603.2$ & $8,535.6$ \\
\hline Deposits from nooresidents & $11,566.1$ & $9,992.7$ & $9,531.1$ & $10,612.4$ & $7,513.1$ & $7,709.3$ & $7,545.0$ & $8,058.0$ \\
\hline Foreign beriks & $8,530.7$ & $6,641.4$ & $6,267.1$ & $7,472.7$ & $5,495.3$ & $\$, 568.4$ & $5,397.3$ & $5,866.4$ \\
\hline Private nonresidants & $3,015.4$ & $3,351.3$ & $3,263,9$ & $3,139.7$ & $2,017.8$ & $2,140.8$ & $2,147.3$ & $2,191.6$ \\
\hline Other foreign tiabilities & $2,380.5$ & $2,798.8$ & $3,467.2$ & 3.673 .5 & $3,808.3$ & $3,569.4$ & $3,375.4$ & $3,837.2$ \\
\hline Net domestic reserves & -684.4 & $\$ 858.8$ & -6143 & -722.1 & -845.3 & -631.3 & -867.6 & -688.2 \\
\hline Domestic currency & 14.4 & 16.4 & 10.1 & 14.7 & 12.0 & 18.8 & 11.8 & 10.0 \\
\hline Interbank deposits (net) & -698.8 & -875.1 & -624.4 & .736 .9 & .857 .3 & -650.0 & -879.4 & -698.2 \\
\hline Net domestic assetw & $4,809.1$ & $5,498,4$ & $5,980.3$ & $6,925.3$ & $8,375.6$ & $9,810.2$ & $9,570,1$ & $10,904.1$ \\
\hline Public seetcr (net) & 74.3 & 62.3 & 72.5 & 1519 & 54.5 & 121.8 & 111.6 & 140.5 \\
\hline Credit. & 74.3 & 62.3 & 72.5 & 152.0 & 54.6 & 121.8 & 111.6 & 140.5 \\
\hline Deposits & 0.0 & 0.0 & 0.0 & 0.0 & 0.0 & 0.0 & 0.0 & 0.0 \\
\hline Private sector & $5,118.6$ & $5,852.4$ & $6,354.4$ & $7,237.5$ & $9,041.8$ & $10,528.3$ & $10,179.8$ & $11,490.9$ \\
\hline Unchassified assets (net) & -383.8 & -416.3 & 446.7 & -464.1 & -720.8 & -839.9 & -721.3 & -727.4 \\
\hline Liabilities to the private sector & $5,895.4$ & 6.373 .7 & $6,895.5$ & $7,973.3$ & $8,994.3$ & $9,696.5$ & $9,578.8$ & $10,364.6$ \\
\hline Monetary liabilities & $4,574.1$ & $4,941.9$ & $5,234.7$ & $6,028.2$ & $6,822.7$ & $7,438.8$ & $7,314.1$ & $7,877.9$ \\
\hline Dernand depposits & 728.6 & 737.7 & 758.3 & 889.7 & $1,027.5$ & $1,062.2$ & 949.6 & 897.6 \\
\hline Time and savings deposits & $3,845.5$ & $4,204.2$ & $4,476.5$ & $5,138.6$ & $5,795.3$ & $6,376.7$ & $6,364,5$ & $6,980.3$ \\
\hline Tine deposits & $3,136.2$ & $3,483.2$ & $3,672.5$ & $4,203.1$ & $4,700.8$ & $5,140.6$ & $5,150.5$ & $5,757.8$ \\
\hline Savings deposits & 709.2 & 721.0 & 804.0 & 935.5 & $1,094.5$ & $1,236.1$ & {$[, 214,0$} & 1.222 .4 \\
\hline Private capital and surplus & $6,321.3$ & $1,431.8$ & $1,660.8$ & $1,945.1$ & $2,571.5$ & $2,257.7$ & $2,264.8$ & $2,486.7$ \\
\hline \multicolumn{9}{|c|}{ III. Savings Bank } \\
\hline Fortign essets (net) & -5.0 & $-1,1$ & -2.0 & -1.5 & 1.4 & 9.7 & 2.4 & $\begin{array}{l}4.3 \\
0.0\end{array}$ \\
\hline Net domestic rewerves & 60.1 & 118.4 & 146.3 & $16] .4$ & 184.0 & 175.2 & 188.9 & 225.6 \\
\hline Domestic eurrency & 0.9 & 0.2 & 0.2 & 0.2 & 0.1 & 0.0 & 0.1 & 0.1 \\
\hline Deposits in local banks (net) & 55.1 & 114.2 & 142.1 & 157.9 & 180.3 & 171.8 & 184.5 & 223.4 \\
\hline Derrand deposits & 10.6 & 0.6 & 2.2 & 3.8 & 3.0 & 4.7 & 4.5 & 5.8 \\
\hline Time deposita & 78.2 & 127.3 & 165.0 & 188.7 & 183.4 & 167.1 & 188.9 & 217.6 \\
\hline Deposits of banks & -33.7 & -13.7 & -25.1 & -34.7 & .6 .1 & 0.0 & -8.9 & 0.0 \\
\hline Cheoks in clearing $4 /$ & 4.1 & 4.1 & 4.0 & 3.3 & 3.7 & 3.4 & 4.3 & 2.1 \\
\hline Net domestic assets. & 215.8 & 189.0 & 175.6 & 188.1 & 177.0 & 204.8 & 194.3 & 168.0 \\
\hline Public sector (net) & -31.9 & .67 .6 & .77 .1 & -86.6 & -108.6 & -105.0 & -108.7 & $-203,8$ \\
\hline Centsal government & 1.1 & 2.2 & 5.9 & 4.7 & 0.7 & 3.7 & 0.7 & 0.7 \\
\hline Loenis and advances. & 1.1 & 2.2 & 5.9 & 4.7 & 0.7 & 3.7 & 0.7 & 0.7 \\
\hline Deposits & 0.0 & 0.0 & 0.0 & 0.0 & 0.0 & 0.0 & 0.0 & 0.0 \\
\hline Rest of public sector & -32.9 & -69.8 & -83.0 & -91.3 & -109.3 & -108.7 & -109.3 & -204.5 \\
\hline Loans and advances & 0.0 & 0.0 & 0.0 & -18.0 & -96.0 & -96.0 & -96.0 & -136.0 \\
\hline Deposits & -32.9 & -69.8 & -83.0 & -73.3 & -133 & -12.7 & -13.3 & -68.5 \\
\hline Private sector & 336. 1 & 349.6 & 353.3 & 388.3 & 398.6 & 424.5 & 415.9 & 455.9 \\
\hline Loans and discounts & 336.0 & 349.5 & 353.2 & 356.8 & 362.9 & 383.6 & 375.2 & 421.7 \\
\hline Investment & 0.1 & 0.1 & 0.1 & 31.4 & 35.7 & 40.9 & 40.7 & 34.2 \\
\hline Unclassified nssets (net) & -5.5 & -4.0 & -20.2 & -22.9 & -16.9 & -18.7 & -14.3 & 16.3 \\
\hline Official capital and surplus & 82.9 & 89.0 & 80.4 & 90.7 & 96.0 & 96.0 & 98.7 & 100.4 \\
\hline
\end{tabular}


Table 27. Panama: Accounts of the Banking System 1/ (Concluded)

(In millions of balbotats and of peried)

\begin{tabular}{|c|c|c|c|c|c|c|c|c|}
\hline & \multirow[b]{2}{*}{1994} & \multirow[b]{2}{*}{1995} & \multirow[b]{2}{*}{1996} & \multirow[b]{2}{*}{1997} & \multirow[b]{2}{*}{1998} & \multirow[b]{2}{*}{1,999} & \multicolumn{2}{|c|}{ Seplember } \\
\hline & & & & & & & 1999 & 2000 \\
\hline Lisblities to domestic private sector & 270.9 & 306,4 & 319.9 & 348.9 & 362,4 & 389.6 & 385.6 & 397.9 \\
\hline Denand deposits & $1 \mathbf{1 2}$ & 15.4 & 7.3 & 6.3 & 7.4 & 11.0 & 11.7 & 11.8 \\
\hline Time and saving deposits & 259.7 & 291.0 & 312.5 & 341.7 & 355.1 & 378.6 & 373.8 & 386.1 \\
\hline Time deposits & 990 & 111.8 & 113.5 & 132.6 & 127.5 & 134.9 & 131.7 & 146.1 \\
\hline Savings deporits & 160.7 & 179.2 & 199.1 & 2052 & 227.5 & 243.7 & 242.2 & 240.1 \\
\hline \multicolumn{9}{|c|}{ IV. Consolidated Banking Systen } \\
\hline Net forelen assets & $2,197.8$ & 2,1903 & $2,405.8$ & $2,784.8$ & $2,313.6$ & $1,295.6$ & $1,697.2$ & 992.1 \\
\hline Assets & $6,406.4$ & $5,425.1$ & $6,253.6$ & $6,420.3$ & $4,996.2$ & $4,673.9$ & $4,635,9$ & $4,965.7$ \\
\hline Lialbilities & $1,177.0$ & $1,466.9$ & $1,098.5$ & 674.2 & 530.7 & 669.8 & 616.9 & 608.4 \\
\hline Overseas operitions (pet) & $-3,031.6$ & $-1,767.9$ & $-2,749.3$ & $-2,961,3$ & $-2,151.9$ & $-2,708.6$ & $-1,321.8$ & $-3,365,2$ \\
\hline Credit to nonresidents & $10,919.6$ & $11,028.3$ & $10,253.6$ & $11,328.7$ & $9,775.3$ & $8,574.8$ & $8,603.2$ & $8,535.6$ \\
\hline Deposits fromn nonresidents & $11,370.7$ & $9,997.4$ & $9,535.8$ & $10,616.5$ & $7,518.9$ & $7,714.0$ & $7,549.7$ & $8,063,6$ \\
\hline Other foreign lisbilities & $2,380.5$ & $2,798.8$ & $3,467.2$ & $3,673,5$ & $3,808.3$ & $3,569.4$ & $3,375.4$ & $3,837.2$ \\
\hline Net donthatic assets & $4,221.0$ & $4,757.8$ & $5,104,4$ & 5,8902 & $7,423.0$ & $9,179.2$ & $8,657,2$ & $10,186.1$ \\
\hline Publis sector (net) & -801.1 & $-1,030,6$ & -857.7 & $-1,007.4$ & $-1,112.3$ & $-1,180.9$ & $-1,098.7$ & -1.244 .7 \\
\hline Crodit & 963,4 & 911,0 & $1,112.3$ & $1,094,0$ & 942.0 & 914.9 & 928.3 & 798.2 \\
\hline Deposits & $-1,764.5$ & $\cdot 1,941.7$ & $-1,970.0$ & $-2,101.4$ & $-2,054.2$ & $-2,095.7$ & $-2,027.0$ & $-2,042.9$ \\
\hline Private sector & $5,755,6$ & $6,520.9$ & $7,008.8$ & $3,948.1$ & $9,843.6$ & $11,536.6$ & $11,118.1$ & $12,682.0$ \\
\hline Official eapitat and surplus & 272.8 & 347.6 & 467.5 & 526.7 & 602.9 & 596.0 & 607.5 & 609.7 \\
\hline Unclassified assets (net) & -429.0 & -427.6 & -460.1 & -484.9 & -716.3 & -835.1 & -716.3 & -662.4 \\
\hline Other assets (net) & 428.9 & 432.2 & 472.8 & 528.4 & 688.9 & 734.6 & 710.7 & 9943 \\
\hline Other items (net) & 857.9 & 859.8 & 932.9 & $1,013.3$ & $1,385.2$ & $1,569.7$ & $1,426.9$ & $1,656.7$ \\
\hline USAID facility & -29.0 & -9.3 & -1.2 & -0.9 & -0.8 & 0.0 & -0.8 & 0.0 \\
\hline Net domestic reserven & -31.7 & 42.8 & -119.2 & -48.9 & 10.8 & 254.5 & -38.5 & 20.9 \\
\hline Domestic currency & 17.9 & 18.8 & 12,5 & 17.1 & 14.7 & 21.7 & 14.8 & 14.2 \\
\hline Net interbank deposits & -75.2 & $-18,9$ & -161.2 & -92.0 & -41.4 & 172.3 & .79 .9 & -18.2 \\
\hline Checks in clearing $4 /$ & 29.9 & 47.5 & 33.5 & 29.7 & 45.7 & 68.5 & 34.2 & 31.4 \\
\hline Cashier's checks in circulation & -4.3 & -4.5 & -4.1 & -3.7 & -82 & -8.1 & -7.6 & -6.4 \\
\hline Labnities to domestie private sector & $6,418,9$ & $6,948.1$ & $7,510.2$ & $8,665.0$ & $9,736,7$ & $10,474.7$ & $10,354.4$ & $11,178.3$ \\
\hline Monetary linbilitics & $5,097.5$ & $5,516.2$ & $5,849.4$ & $6,719.9$ & $7,565.2$ & $8,217.0$ & $8,089.6$ & $8,691.6$ \\
\hline Demand deposits & 799.9 & 816.1 & 833.2 & 595.2 & $1,131.4$ & $1,165.3$ & $4,053.3$ & 971.8 \\
\hline Time and savings deposits & $4,297.7$ & $4,700.1$ & $5,016.2$ & $3,724.8$ & $6,4 \mathbf{3 3} .7$ & $7,051.8$ & $7,036.3$ & $7,719,8$ \\
\hline Time deposits & $3,348.7$ & $3,709.7$ & $3,903.6$ & $4,454.1$ & $4,953.2$ & 5.391 .4 & $5,401.9$ & $6,064,8$ \\
\hline Savings deposits & 949.0 & 990.5 & $1,112.6$ & $1,270.7$ & $1,480.5$ & $1,660.4$ & $1,634.4$ & $1,655.0$ \\
\hline Private capital anc surplus & $1,321.3$ & $1,431.8$ & $1,660.8$ & $1,945.1$ & $2,171.5$ & $2,257.7$ & $2,264.8$ & $2,486.7$ \\
\hline
\end{tabular}

Sounces: National Bank of Panama, Superintendency of Banks, and The Savings Bank.

1/ Exejudes operations of international banks which are licensed to perform onily offshore operations, but includes the offshore operations of banks licensed to perform both comestic and offishore operations.

2/ Not included in BNP accounts sizce 1987, but is included in the Central Government Accounts

3/ Excluding the use of Fund credit.

4/ Ineludes bonds issued by the Central Government furing $1988-89$ in lieu of payment in cash to govemment employees of the 13 th-month salary bonus. 
Table 28. Panama: Summary Operations of the Banking System

\begin{tabular}{|c|c|c|c|c|c|c|c|c|}
\hline & \multirow[b]{2}{*}{1994} & \multirow[b]{2}{*}{1995} & \multirow[b]{2}{*}{1996} & \multirow[b]{2}{*}{1997} & \multirow[b]{2}{*}{1998} & \multirow[b]{2}{*}{1999} & \multicolumn{2}{|c|}{ September } \\
\hline & & & & & & & 1999 & 2000 \\
\hline \multicolumn{9}{|c|}{ (In percent of GDP) } \\
\hline Ner domestic assets & 54.6 & 60.2 & 62.6 & 67.9 & 81.2 & 96.2 & 90.7 & 102,8 \\
\hline Public sector (net) & -10.4 & -13.0 & -10.5 & -11.6 & -12.2 & -12.4 & -11.5 & -12.6 \\
\hline Private sector & 74.4 & 82.5 & 86.0 & 91.8 & 107.7 & 120.9 & 116.5 & 128.0 \\
\hline Other & -9.1 & -9.8 & -11.4 & -11.7 & -14.4 & -15.0 & $-13,9$ & -12.8 \\
\hline Liabilities to domestic private sector & 83.0 & 87.9 & 92,1 & 100.1 & 106.5 & 109.7 & 108.5 & 112.8 \\
\hline Monetary liabilities & 65.9 & 69.8 & 71.8 & 77.6 & 82.7 & 86.1 & 84.7 & 87.7 \\
\hline Demand deposits & 10.3 & 10.3 & 10.2 & 11.5 & 12.4 & 12.2 & 11.0 & 9.8 \\
\hline Time and saving deposits & 55.6 & 59.4 & 61.5 & 66.1 & 70.4 & 73.9 & 73.7 & 77.9 \\
\hline Time deposits & 43.3 & 46.9 & 47.9 & 51.4 & 54.2 & 56.5 & 56,6 & 61.2 \\
\hline Savings depasits & 12.3 & 12.5 & 13.6 & 14.7 & 16.2 & 17.4 & 17.1 & 16.7 \\
\hline Private capital and surplus & 17.1 & 18.1 & 20.4 & 22.5 & 23.7 & 23.7 & 23.7 & 25,1 \\
\hline \multicolumn{9}{|c|}{ (12-month change)1/ } \\
\hline Net domestic assets & 8.0 & 8.4 & 5,0 & 10.3 & 17.8 & 18.0 & 15.5 & 14.8 \\
\hline Public sector (net) & -5.5 & -3.6 & 2.5 & -2.0 & -1.2 & -0.7 & $-1,3$ & $-1,4$ \\
\hline Private sector & 14.2 & 11.9 & 7,0 & 12.5 & 21.9 & 17.4 & 17.0 & 15.1 \\
\hline \multicolumn{9}{|c|}{ (12-month change) $y$} \\
\hline \multicolumn{9}{|l|}{ Liabilities to the private sector } \\
\hline Monetary liabilities & 17.9 & 8.2 & 8.1 & 15.4 & 12.4 & 9.4 & 12.2 & 8.0 \\
\hline Money & 12.1 & 6.5 & 4.8 & 11.6 & 9.8 & 8.3 & 10.3 & 5.8 \\
\hline Quasi-money & 1.8 & 0.3 & 0.2 & 2.2 & 1.6 & 0.7 & 1.2 & -0.8 \\
\hline Time deposits & 10.4 & 6.3 & 4.5 & 9.4 & 8.2 & 7.6 & 9.1 & 6.6 \\
\hline \multirow[t]{2}{*}{ Savings deposits } & 9.0 & 5.6 & 2.8 & 7.3 & 5.8 & 4.9 & 6.8 & 6.4 \\
\hline & 1.3 & 0.6 & 1.8 & 2.1 & 2.4 & 2.7 & 2.2 & 0.2 \\
\hline
\end{tabular}

Sources: National Bank of Panama; Superintendency of Banks; and The Savings Bank.

1/ Percentage change in respect to bank liabilities to the private sectors at the beginning of the period. 
Table 29. Panama: Private Sector Deposits

\begin{tabular}{|c|c|c|c|c|c|c|c|c|}
\hline & \multirow[b]{2}{*}{1994} & \multirow[b]{2}{*}{1995} & \multirow[b]{2}{*}{1996} & \multirow[b]{2}{*}{1997} & \multirow[b]{2}{*}{1998} & \multirow[b]{2}{*}{1999} & \multicolumn{2}{|c|}{ September } \\
\hline & & & & & & & 1999 & 2000 \\
\hline \multicolumn{9}{|c|}{ (In millions of balboas: end of period) } \\
\hline Total private sector deposits & 5097.5 & 5516.2 & $5,849.4$ & $6,719.9$ & $7,565.2$ & $8,217.0$ & $8,089,6$ & $8,691,6$ \\
\hline Demand & 799.9 & 816.1 & 833.2 & 995.2 & 1,131.4 & $1,165.3$ & $1,053.3$ & 971.8 \\
\hline National Bank & 60.1 & 63.0 & 67.6 & 99.3 & 96.6 & 92.1 & 92.0 & 62.4 \\
\hline Savings Bank & 11.2 & 15.4 & 7.3 & 6.3 & 7.4 & 11.0 & 11.7 & 11.8 \\
\hline Private banks & 728.6 & 737.7 & 758.3 & 889.7 & $1,027.5$ & $1,062.2$ & 949.6 & 897.6 \\
\hline Time and savings & 4297.7 & 4700.1 & $5,016.2$ & $5,724,8$ & $6,433.7$ & $7,051.8$ & $7,036.3$ & $7,719.8$ \\
\hline National Bank & 192.5 & 204.9 & 227.2 & 244.4 & 283.4 & 296.5 & 298.0 & 353.4 \\
\hline Savings Bank & 259.7 & 291.0 & 312.5 & 341.7 & 355.1 & 378.6 & 373.8 & 386.1 \\
\hline Private banks & 3845.5 & 4204.2 & $4,476.5$ & $5,138.6$ & $5,795.3$ & $6,376.7$ & $6,364.5$ & $6,980.3$ \\
\hline Time deposits & 3348.7 & 3709.7 & $3,903.6$ & $4, \mathbf{4 5 4 . 1}$ & $4,953,2$ & $5,391,4$ & $5,411.9$ & $6,064.8$ \\
\hline National Bank & 113.4 & 114.6 & 117.7 & 118.4 & 124.8 & 115.9 & 119.7 & 160.9 \\
\hline Savings Bank & 99.0 & 111.8 & 113.5 & 132.6 & 127.5 & 134.9 & 131.7 & 146.1 \\
\hline Private banks & 3136.2 & 3483.2 & $3,672,5$ & $4,203.1$ & $4,700,8$ & $5,140,6$ & $5,150.5$ & $5,757.8$ \\
\hline Savings deposits & 949.0 & 990.5 & $1,112.6$ & $1,270.7$ & $1,480.5$ & $1,660.4$ & $1,634.4$ & $1,655.0$ \\
\hline National Bank & 79.1 & 90.3 & 109.5 & 126.0 & 158.6 & 180.6 & 178.3 & 192.5 \\
\hline Savings Bank & 160.7 & 179.2 & 199.1 & 209.2 & 227.5 & 243.7 & 242.2 & 240.1 \\
\hline Private banks & 709.2 & 721.0 & 804.0 & 935.5 & $1,094.5$ & $1,236.1$ & $1,214,0$ & $1,222.4$ \\
\hline \multicolumn{9}{|c|}{ (Percentage change over previous 12 -month period) } \\
\hline Total private sector deposits & 14.9 & 8.2 & 6.0 & 14.9 & 12.6 & 8.6 & 13.2 & 7.4 \\
\hline Demand & 13.6 & 2.0 & 2.1 & 19.4 & 13.7 & 3.0 & 11.4 & -7.7 \\
\hline Time and savings & 15.1 & 9.4 & 6.7 & 14.1 & 12.4 & 9.6 & 13.5 & 9.7 \\
\hline $\begin{array}{l}\text { Time } \\
\text { Savings }\end{array}$ & $\begin{array}{r}17.2 \\
8.3\end{array}$ & $\begin{array}{r}10.8 \\
4.4\end{array}$ & $\begin{array}{r}5.2 \\
12.3\end{array}$ & $\begin{array}{l}14.1 \\
14.2\end{array}$ & $\begin{array}{l}11.2 \\
16.5\end{array}$ & $\begin{array}{r}8.8 \\
12.1\end{array}$ & $\begin{array}{l}13.2 \\
14.5\end{array}$ & $\begin{array}{r}12.3 \\
1.3\end{array}$ \\
\hline
\end{tabular}

Sources: National Bank of Panama; Superintendency of Banks; and The Savings Bank. 
Table 30. Panama: Offshore Operations of Private Banks 1/

(In billions of U.S. dollars, end of period)

\begin{tabular}{|c|c|c|c|c|c|c|c|c|}
\hline & \multirow[b]{2}{*}{1994} & \multirow[b]{2}{*}{1995} & \multirow[b]{2}{*}{1996} & \multirow[b]{2}{*}{1997} & \multirow[b]{2}{*}{1998} & \multirow[b]{2}{*}{1999} & \multicolumn{2}{|c|}{ September } \\
\hline & & & & & & & 1999 & 2000 \\
\hline Foreign assets & 22.8 & 22.7 & 21.6 & 22,9 & 20.9 & 19.7 & 19.2 & 19,6 \\
\hline Foreign reserves & 8.4 & 7.0 & 7.3 & 7.7 & 6.1 & 6.5 & 5.8 & 7.1 \\
\hline General license banks & 5.7 & 4.6 & 5.2 & 5.3 & 4.0 & 3.8 & 3.7 & 4.0 \\
\hline Offshore banks 2 & 2.7 & 2.4 & 2.0 & 2.4 & 2.1 & 2.7 & 2.1 & 3.1 \\
\hline Credit to nonresidents & 14.4 & 15.6 & 14.3 & 15.2 & 14.8 & 13.2 & 13.4 & 12.5 \\
\hline General license banks & 10.9 & 11.0 & 10.3 & 11.3 & 9.2 & 8.6 & 8.6 & 8.5 \\
\hline Offshore banks & 3.5 & 4,6 & 4.0 & 3.9 & 5.6 & 4.7 & 4.8 & 4.0 \\
\hline Foreign liabilities & 20.8 & 20.7 & 19.9 & 20.9 & 19.5 & 18.9 & 18.1 & 19.1 \\
\hline Short-term liabilities & 1.1 & 1.3 & 1.1 & 0.7 & 0.7 & 0.5 & 0.5 & 0.5 \\
\hline General license banks & 0.9 & 1.1 & 1.0 & 0.5 & 0.4 & 0.6 & 0.5 & 0.5 \\
\hline Offshore banks & 0.3 & 0.2 & 0.1 & 0.2 & 0.3 & 0.0 & 0.0 & 0.0 \\
\hline Deposits from nonresidents & 17.2 & 16.5 & 15.3 & 16.5 & 14.7 & 14.1 & 13.7 & 14.1 \\
\hline General license banks & 11.6 & 10.0 & 9.5 & 10.6 & 7.5 & 7.7 & 7.5 & 8.1 \\
\hline Banks & 8.6 & 6.6 & 6.3 & 7,5 & 5.5 & 5.6 & 5.4 & 5,9 \\
\hline Nonbanks & 3.0 & 3.4 & 3.3 & 3.1 & 2.0 & 2.1 & 2.1 & 2,2 \\
\hline Offshore banks & 5.7 & 6.6 & 5.8 & 5.9 & 7.1 & 6.4 & 6.2 & 6.0 \\
\hline Other liabilities & 2.4 & 2.8 & 3.5 & 3.7 & 4.2 & 4.3 & 3.9 & 4.5 \\
\hline General license banks & 2.4 & 2.8 & 3.5 & 3.7 & 3.8 & 3.6 & 3.4 & 3.8 \\
\hline Offshore banks & 0.0 & 0.0 & 0.0 & 0.1 & 0.4 & 0.8 & 0.5 & 0.7 \\
\hline Capital and reserves & 0.3 & 0.3 & 0.3 & 0.4 & 0.3 & 0.3 & 0.3 & 0.4 \\
\hline
\end{tabular}

Source: Superintendency of Banks.

1/ Includes offshore operations of international license banks.

2/ Refers to intemational license banks. 
Table 31. Panama: Interest Rate Structure

\begin{tabular}{|c|c|c|c|c|c|c|c|c|}
\hline & \multirow[b]{2}{*}{1994} & \multirow[b]{2}{*}{1995} & \multirow[b]{2}{*}{1996} & \multirow[b]{2}{*}{1997} & \multirow[b]{2}{*}{1998} & \multirow[b]{2}{*}{1999} & \multicolumn{2}{|c|}{ September } \\
\hline & & & & & & & 1999 & 2000 \\
\hline \multicolumn{9}{|l|}{ Lending rates (less than one year) } \\
\hline Commercial & 10.2 & 10.6 & 10.5 & 10.2 & 9.9 & 9.9 & 10.0 & 9.9 \\
\hline Industrial & 9.8 & 10.1 & 10.1 & 9.3 & 9.0 & 8.6 & 8.0 & 9.2 \\
\hline Personal & 12.5 & 12.6 & 12.2 & 12.6 & 12.9 & 13.3 & 13.3 & 13.1 \\
\hline Domestic deposit rate (six-month) $1 /$ & 5.5 & 6.5 & 6.4 & 6.2 & 6.1 & 6.2 & 6.5 & 6.4 \\
\hline U.S. prime rate (six-month) & 7.1 & 8.8 & 8.5 & 8.5 & 8.3 & 7.9 & 8.1 & 9.5 \\
\hline LIBOR (six-month) & 5.1 & 6.1 & 5.6 & 5.9 & 5.5 & 5.3 & 5.9 & 6.8 \\
\hline $\begin{array}{l}\text { Difference between the deposit rate } \\
\text { and LIBOR }\end{array}$ & 0.4 & 0.4 & 0.8 & 0.3 & 0.6 & 0.8 & 0,6 & -0.4 \\
\hline
\end{tabular}

Source: Superintendent of Eanks. 
Table 32. Panama: Banking System Credit to the Domestic Private Sector by Economic Activity

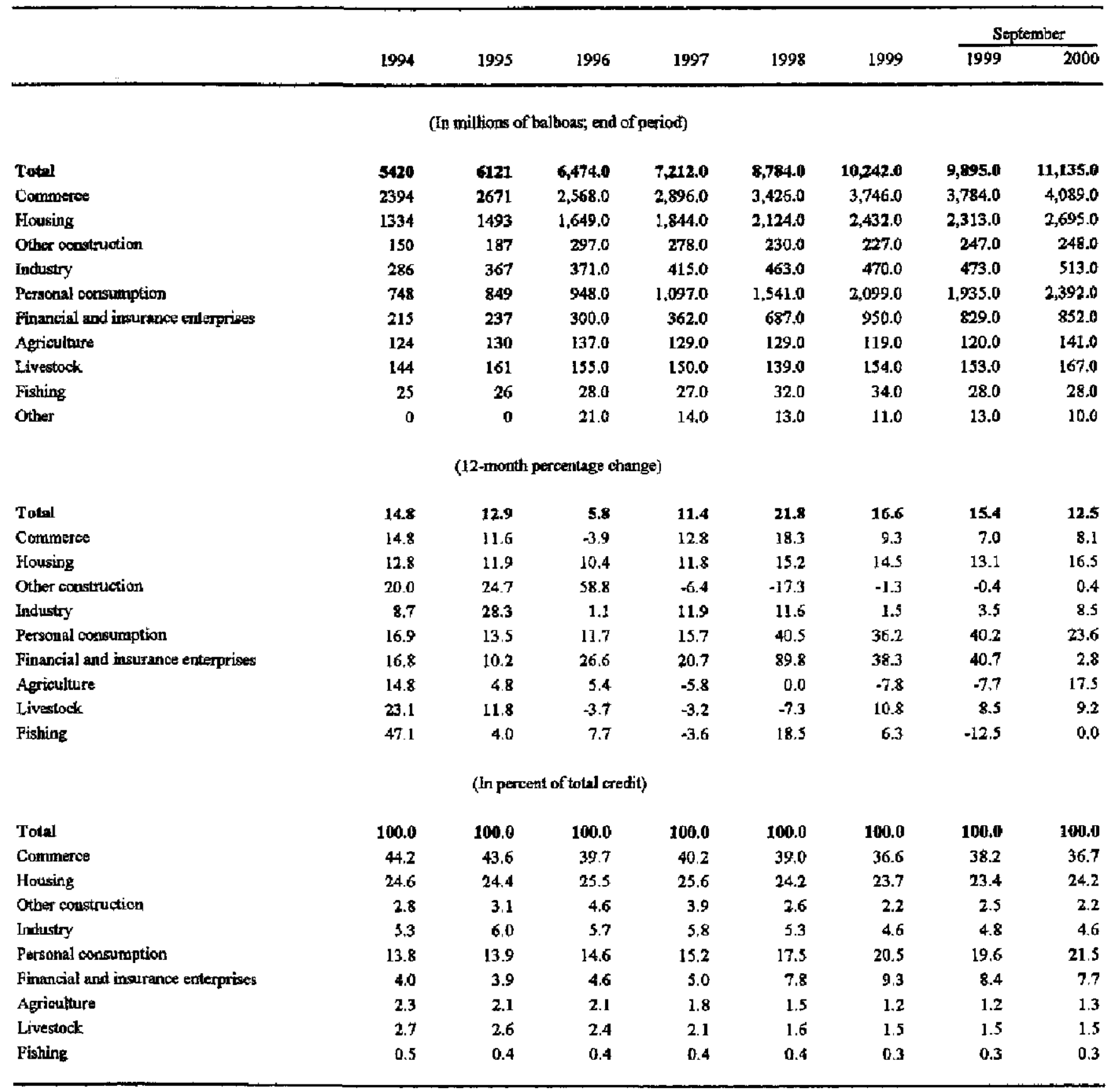

Source: Superintendent of Banks. 
Table 33. Panama: Public Sector Banks-Operating Revenue and Expenditure (In millions of balboas)

\begin{tabular}{|c|c|c|c|c|c|c|c|c|}
\hline & \multirow[b]{2}{*}{1994} & \multirow[b]{2}{*}{1995} & \multirow[b]{2}{*}{1996} & \multirow[b]{2}{*}{1997} & \multirow[b]{2}{*}{1998} & \multirow[b]{2}{*}{1999} & \multicolumn{2}{|c|}{ September } \\
\hline & & & & & & & 1999 & $\overline{2000}$ \\
\hline \multicolumn{9}{|c|}{ L. National Bank of Panama Operating Revenue and Expenditure } \\
\hline Operating profits or Josses (-) & 33.2 & 59.9 & 57.7 & 44.8 & 77.6 & 105.1 & 89.1 & 898 \\
\hline Operating revenue & 624 & 89.1 & 89.1 & 76.7 & 115.8 & 144.8 & 113.0 & 1166 \\
\hline Net interesi & $\mathbf{5 1 . 6}$ & 78.1 & 77.7 & 65.3 & 89.9 & 130.4 & 102,3 & 111.1 \\
\hline Interest reseipts (calh) & 98.5 & 139.3 & 142.4 & 144.2 & 173.2 & 222.6 & 163.9 & 191.2 \\
\hline Collected & 104.5 & 143.5 & 143.7 & 148.5 & 177.1 & 222.6 & 164.6 & 191.2 \\
\hline Not yet collected 3/ & $-6,0$ & -4.2 & -1.3 & -4.4 & -3.9 & 0.0 & -0.8 & 0.0 \\
\hline interest payments acerued & -46.9 & -61.2 & -64.7 & -78.9 & -83.3 & -92.2 & -61.6 & -80.2 \\
\hline Non interest inconte & 10.8 & 11.1 & 103 & 11.4 & 259 & 14.4 & 10.7 & 5.6 \\
\hline Operating expewditure & 29.2 & 29.2 & 30.4 & 32.0 & $\mathbf{3 8 . 2}$ & 39.7 & 23.9 & $\mathbf{2 6 , 8}$ \\
\hline Wages and salaries & 19.2 & 19.1 & 19.6 & 20.4 & 222 & 22.1 & 15.1 & 16.3 \\
\hline Goods and services & 8.4 & 8.7 & 10.2 & 11.0 & 13.7 & 13.3 & 8.4 & 10.1 \\
\hline Other & 1.6 & 1.3 & 0.6 & 0.6 & 2.2 & 4.3 & 0.4 & 0.4 \\
\hline \multicolumn{9}{|c|}{ II. Savings Bank } \\
\hline Opernting profits or lopses (-) & 3.6 & 1.2 & 4.6 & 3.3 & 3.2 & 2.8 & 3.4 & 6.3 \\
\hline Operating revenue & 17.9 & 17.6 & 22.1 & 21.9 & 25.8 & 24.8 & 17.6 & 22.3 \\
\hline Net interest & 16.3 & 16.7 & 163 & 16.9 & 223 & 21.0 & 14.6 & 16.8 \\
\hline Interest receipts (cosh) & 34.6 & 40.9 & 43.4 & 47.9 & $\mathbf{5 3 . 2}$ & 52.8 & 38.9 & $\mathbf{4 4 . 3}$ \\
\hline Collected & 42.5 & 47.9 & 45.7 & 50.3 & $\$ 3.2$ & 32.8 & 389 & 44.3 \\
\hline Loans & 37.7 & 38.2 & 36.3 & 36.2 & 37.4 & 36.8 & 26.9 & 30.1 \\
\hline Fixed deposits & 3.5 & 8.4 & 9.3 & 12.3 & 12.7 & 12.3 & 9.2 & 10.9 \\
\hline Investments & 1.3 & 1.3 & 0.1 & 1.8 & 3.1 & 3.7 & 2.9 & 3.3 \\
\hline Not yet collected $1 f$ & -8.0 & -7.0 & -2.4 & -2.3 & & 0.0 & 0.0 & 0.0 \\
\hline Interest payments accrued & -18.3 & -24.1 & -27.1 & -31.1 & -30.9 & -31.8 & -24.3 & -27.5 \\
\hline Non interest income & 1.6 & 0.9 & 5.8 & 5.1 & 3.4 & 3.8 & 3.1 & 5.5 \\
\hline Operating expenditure (cush) & 14.3 & 16.4 & 17.6 & 18.6 & 22.6 & 22.0 & 14.2 & 16.1 \\
\hline Expenditures & 22.7 & 20.3 & 21.0 & 20.7 & 24.7 & 24.5 & 16,0 & 17,9 \\
\hline \multicolumn{9}{|l|}{ Of which: } \\
\hline Wages and salaries & 8.2 & 10.5 & 11.4 & 11.8 & 12.6 & 13.2 & 9.9 & 10.1 \\
\hline \multicolumn{9}{|l|}{ Goods and services } \\
\hline \multicolumn{9}{|l|}{ Other } \\
\hline Deppreciation & -1.4 & -1.5 & -1.5 & -1.4 & -1.4 & -1.6 & -1.1 & -1.4 \\
\hline Provisions for bad loans & $-7,0$ & -2.3 & -2.0 & -0.7 & -0.8 & -0.9 & -9.7 & -0.4 \\
\hline
\end{tabular}


Table 33. Panama: Public Sector Banks - Operating Revenue and Expenditure (Concluded) (In millions of balboas)

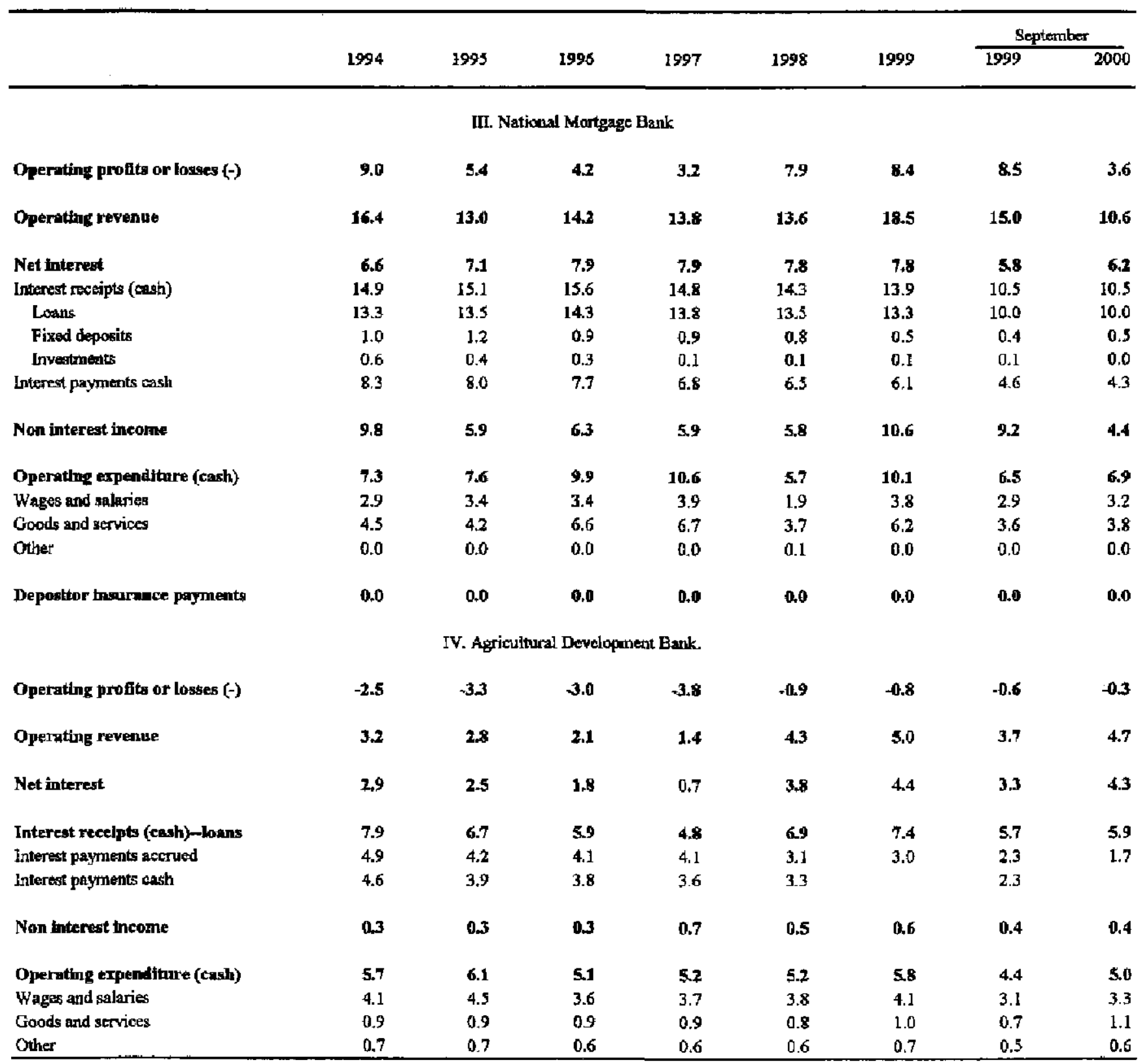

Sources: National Bank of Panama: Savings Bank; National Mortgage Bank; and the Agricultural Development Bank.

1/ Difference of interest receivable at the begining and at the end of the period.

2f In 1993 excludes B12.7 million of reversion of reserves for bad loans.

3/ Includes exchange losses of B 0.4 million in 1993, B 1.2 million in 1994 and B 0.9 million in repayments, and exchange profit of B 0.5 million in. 1996. Adjustment for settlement of IMF operations between the BNP and the central government. 
Table 34. Panama: Public Sector Banks-Fortfolio in Arrears

\begin{tabular}{|c|c|c|c|c|c|c|c|}
\hline & \multirow[b]{2}{*}{1995} & \multirow[b]{2}{*}{1996} & \multirow[b]{2}{*}{1997} & \multirow[b]{2}{*}{1998} & \multirow[b]{2}{*}{1999} & \multicolumn{2}{|c|}{ September } \\
\hline & & & & & & 1999 & 20001 \\
\hline \multicolumn{8}{|c|}{ I. National Bank of Panama } \\
\hline Tatal private aector portfollo 2 r & 276.9 & 268.6 & 260.6 & 327.6 & 533.9 & 472.7 & 677.9 \\
\hline Commerce & 39.1 & 36.8 & 43.4 & 45.5 & 58.2 & $\$ 1.2$ & 83.4 \\
\hline Agricuthire and forestry & 78.0 & 79.6 & 81.7 & 83.9 & 104.8 & 96.4 & 120.9 \\
\hline Personal loans & 99.5 & 92.6 & 75.9 & 184.7 & 339.6 & 299.0 & 435.1 \\
\hline Others & 60.2 & 59.6 & 59.6 & 13.4 & 31.4 & 26.1 & 38.5 \\
\hline Total arrears & 10.7 & 11.5 & 11.1 & 10.7 & 10.6 & 12.1 & 14.3 \\
\hline Commerce & 4.3 & 4.1 & 3.3 & 2.6 & 1.7 & 2.6 & 2.2 \\
\hline Agriculture and forestry & 3.7 & 4.4 & 4.7 & 5.0 & 5.0 & 5.5 & 6.7 \\
\hline Personal losms & 1.0 & 0.9 & I.1 & 1.7 & 2,8 & 2.5 & 3.9 \\
\hline Othere & 1.7 & 2.1 & 2.0 & 1.4 & 1.2 & 1.5 & 1.5 \\
\hline Share of arrears bi totel portiolio & 3.9 & 43 & 4.3 & $\mathbf{3 . 3}$ & 2.0 & 2.6 & 2.1 \\
\hline Conmuerce & 10.9 & 11.1 & 7.6 & 5.6 & 2.9 & 5.2 & 2.6 \\
\hline Aqrieulare and forestry & 4.8 & 5.5 & 5.8 & 60 & 4.8 & 5.7 & 5.6 \\
\hline Personal loans & 1.0 & 1.0 & 1.5 & 0,9 & 0.8 & 0.8 & 0.9 \\
\hline Others & 2.8 & 3.6 & 3.4 & 10.8 & 3.7 & 5.8 & 3.8 \\
\hline Loans with payjents overdue & 10.7 & 11.5 & 11.1 & 10.7 & 10.6 & 12.1 & 14.3 \\
\hline Between 30 and 90 days & 3.8 & 5.1 & 4.8 & 4.2 & 5.9 & 6.7 & 7.4 \\
\hline Over 90 days & 6.9 & 6.4 & 6.4 & 6.4 & 4.7 & 5.5 & 6.9 \\
\hline Percent of tott-l with payments overdue & 100.0 & 100.0 & 100.0 & 168.0 & 100.0 & 100.0 & 100.0 \\
\hline Between 30 and 90 days & 35.2 & 44.6 & 42.8 & 39.7 & 56.0 & 35.1 & 51.5 \\
\hline Over 90 days & 64.8 & 53.4 & 57.2 & 60.3 & 44.0 & 44.9 & 48.5 \\
\hline \multicolumn{8}{|c|}{ II. Savings Bank } \\
\hline Total portsolio & 336.9 & 3518 & 355.0 & 362.9 & 383.6 & 375.2 & 421.7 \\
\hline Mortages & 265.4 & 275.1 & 285.8 & 289.4 & 297.2 & 294.6 & 299.6 \\
\hline Personal loans & 60.2 & 62.1 & 55.0 & 60.8 & 74.3 & 68.9 & 109.9 \\
\hline Prendarios & 11.4 & 14.6 & 147 & 12.6 & 12.1 & 11.7 & 13.2 \\
\hline Loans overdoe & 61.6 & 22.8 & 20.1 & 64.8 & 64.5 & 62.9 & 107.3 \\
\hline Mortages & 49.8 & 139 & 11.4 & $\$ 4.1$ & 53.9 & 52.9 & 99.8 \\
\hline Personal losus & 11.1 & 6.4 & 6.3 & 8.6 & 8.1 & 8.1 & 7.2 \\
\hline Other & 0.7 & 2.5 & 2.4 & 2.0 & 2.5 & 1.9 & 0.5 \\
\hline Share of arrears in total portiolio & 18.3 & 6.5 & 5.7 & 17.8 & 16.8 & 16.8 & 0.0 \\
\hline \multicolumn{8}{|l|}{ Share of arrears in their individual portfolios } \\
\hline Mortages & 18.8 & 5.1 & 4.0 & 18.7 & 18.1 & 18.0 & 33.3 \\
\hline Personal loans & 18.5 & 10.3 & 11.5 & 14.2 & 10.9 & 11.7 & 6.5 \\
\hline Other & 6.0 & 17.1 & 16.9 & 16.2 & 20.8 & 16.2 & 3.5 \\
\hline
\end{tabular}


Table 34. Panama: Public Sector Banks-Portfolio in Arrears (Concluded)

\begin{tabular}{|c|c|c|c|c|c|c|c|}
\hline & \multirow[b]{2}{*}{1995} & \multirow[b]{2}{*}{1956} & \multirow[b]{2}{*}{1997} & \multirow[b]{2}{*}{1998} & \multirow[b]{2}{*}{1999} & \multicolumn{2}{|c|}{ Septerpber } \\
\hline & & & & & & 1999 & 200011 \\
\hline Loms overdue 1 / & 61.6 & 22.8 & 20.1 & 64.8 & 64.5 & 0.0 & 0.0 \\
\hline Between 2 and 9 months & 29.5 & $\ldots$ &.- & $\ldots$ & $\cdots$ & $\ldots$ & $\ldots$ \\
\hline More than 9 motiths & 322 & $\ldots$ & $\ldots$ & $\ldots$ & $\ldots$ & $\ldots$ & $\ldots$ \\
\hline Loans overdue (in percent) & 100.0 & 100.0 & 100.0 & 0.0 & 0.0 & 0.0 & 0.0 \\
\hline Detween 2 10 9 months & 47.8 & $\ldots$ & $\ldots$ & $\ldots$ & $\ldots$ & $\ldots$ & $\ldots$ \\
\hline More than 9 months & 52.2 & $\ldots$ & $\ldots$ & $\ldots$ & $\ldots$ & $\ldots$ & $\ldots$ \\
\hline \multicolumn{8}{|c|}{ If. National Housing Bank 3 / } \\
\hline Total portfollo & 174.4 & 188.5 & 195.4 & 204.7 & 233.9 & 2002 & 195.1 \\
\hline Total arrears & 42.2 & 45.6 & 8.1 & 16.0 & 38.6 & 28.6 & 31.9 \\
\hline Share of arrears in total porttolio & 24.2 & 24.2 & 4.1 & 7.8 & 16.5 & 14.3 & 16.4 \\
\hline \multicolumn{8}{|c|}{ IV, Agricultural Development Bank, 4} \\
\hline Total purtfollo & 76.6 & 74.2 & 76.1 & 83.9 & 85.3 & 86.3 & 88.1 \\
\hline Loong ovêrdue & 20.4 & 20.7 & 21.2 & 20.6 & 27.4 & 25.9 & 22.1 \\
\hline Loans nverdule as a share of total portrolio & 26.7 & 27.9 & 27.9 & 24.5 & 32.1 & 30.0 & 25.1 \\
\hline Loans with paynewts overdue & 20.4 & 20.7 & 21.2 & 20.6 & 27.4 & $\mathbf{2 5 . 9}$ & 22.1 \\
\hline Between 30 to 90 days & 0.7 & 1.0 & 1.1 & 1.2 & 4.6 & 3.3 & 2.2 \\
\hline More than 90 days & 19.7 & 19.7 & 20.2 & 19.4 & 22.8 & 22.6 & 20.0 \\
\hline Percent af total with payments overdue & 180.0 & 100.0 & 100.0 & 100.0 & 100.0 & 100.0 & 100.0 \\
\hline Between 30 to 90 deys & 3.4 & 4.9 & 5.0 & 5.8 & 16.9 & 12.8 & 9.7 \\
\hline More than 90 days & 96.6 & 95.1 & 95.0 & 94.2 & 83.1 & 87.2 & 90.3 \\
\hline
\end{tabular}

Sources: National Bank of Panama; The savings Bank; The National Mortgage Bank; and The Agrjecultural Development Banik,

I/ In September 2000 the significant increase in arrears in the accouts of the Caja de Ahorros refitects the decision of the Bank to strictly enforce the recording of any loans more than two days past the thirty-day period from the last payment, as arrears. Given that cheques issued by the Oovernment and state agencies- and some privafe sector firms- to their employes, are sometimes not cleared by commeroial banks on the last working day of the month, fixed deciuotions from this accounts are normally delayed by several days. Most banks cater for this by only includimg in past due those payments outstanding after 45 to 60 days.

2/From 1996 refers to loans overdue by more than 91 dhys.

3/ This portfolio includes bad loans related to projects financed through the Ministry of Housing aid at alleviating the problem of housing for lower income families.

4/ From 1993 the portiolio exaludes bad loans. 
Table 35. Panama: Balance of Payments

(In militions of balboas)

\begin{tabular}{|c|c|c|c|c|c|c|c|c|c|c|c|c|c|c|c|}
\hline & \multicolumn{3}{|c|}{1995} & \multicolumn{3}{|c|}{1996} & \multicolumn{3}{|c|}{1997} & \multicolumn{3}{|c|}{1998} & \multicolumn{3}{|c|}{1999} \\
\hline & Credit & Debit & $\overrightarrow{\text { Balknet }}$ & Credit & Debit & Balunce & Credit & Debit & Balance & Crectit & Debit & $\overline{\text { Bralinate }}$ & Credit & Debit & Balance \\
\hline Current eccount & $9,437.0$ & $9,806.1$ & -369.1 & $8,968.2$ & $9,278.1$ & -301.9 & $9,934.9$ & $10,523,3$ & .584 .4 & $9,967.3$ & $11,169.5$ & $-1,202.2$ & $8,786.8$ & $10,164.3$ & $-1,377.5$ \\
\hline Copeds and serwices & $7,610.4$ & $7,767.7$ & -157.3 & $7,381,2$ & $7,500.7$ & -119.5 & $0,318.1$ & $8,645.5$ & 327.4 & $8,047.1$ & 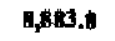 & -836.7 & $7,019.0$ & $7,820.1$ & $-801 . t$ \\
\hline Gionds. & $6,091.0$ & 6,6799 & -588.9 & $5,822.9$ & $6,467.0$ & .644 .1 & $6,669.7$ & $7,354,9$ & -685.2 & $6,349.7$ & $7,711,3$ & $-1,361.6$ & $3,299.5$ & $6,716.0$ & $-1,416.5$ \\
\hline Nonpotrolevin exporte (fo.b.) & $5,945.2$ & 0.0 & $5,945.2$ & $5,655.5$ & 0.0 & $5,655.5$ & $6,508.5$ & 0.0 & $6,508.5$ & 6222.5 & 0.0 & $6,222.5$ & $\$ 991.8$ & 0,0 & $3,091.8$ \\
\hline Potrolenm trade (t.o.b.) & 145.8 & 328.6 & -182.8 & 167.4 & 412.4 & -245.0 & 161.2 & 395.6 & -2344 & 127.2 & 291.4 & -164.2 & 207.7 & 416.4 & -208.7 \\
\hline Nonpetroleum imports $(f, o, b\}$, & 0.0 & $6,351.3$ & $-6,351.3$ & 0.0 & $6,054.6$ & $-6,054.6$ & 0.0 & 6,959.3 & $-6,959,3$ & 0.0 & $7419: 9$ & $-7,419.9$ & 0.0 & 6299.6 & $-6,299.6$ \\
\hline Services & $1,519.4$ & $1,087.8$ & 431.6 & $1,558.3$ & $1,033.7$ & 524.6 & $1,648.4$ & $1,290.6$ & 357.8 & $1,697.4$ & $1,172.5$ & 524.9 & $1,719.5$ & $1,104.1$ & 615.4 \\
\hline Transportation & 783.7 & 744.8 & 38.9 & 777.6 & 677.2 & 100.4 & 834.1 & 786.3 & 47.8 & 880.3 & 654.2 & 226.1 & 923.4 & 628.5 & 294.9 \\
\hline \multicolumn{16}{|l|}{ Of which: } \\
\hline $\boldsymbol{z L}$ & 0.0 & 451.6 & $-4 \$ 1.6$ & 0.0 & 371.2 & -371.2 & 0.0 & 443.8 & -443.8 & 0.0 & 2779 & -277.9 & 0.0 & 236.5 & -236.5 \\
\hline Travel & 309.4 & 120.7 & 188.7 & 359.9 & 140.3 & 219.6 & 374.2 & 153.8 & 218.4 & 378.8 & 176.2 & 202.6 & 387.2 & 184.5 & 202.7 \\
\hline Goverument & 221.7 & 38.6 & 123.1 & 2023 & 33.5 & 168.8 & 206.1 & 46.2 & 159.9 & 134.3 & 49.1 & 91.2 & 100.3 & 47.4 & 52.9 \\
\hline Other servicis & 204.6 & 183.7 & 20.9 & 218.5 & 182.7 & 35.8 & 234.0 & 294.3 & -58.3 & 304.0 & 299.0 & 5.0 & 308.6 & 243.7 & 64.9 \\
\hline Income & $1,644.1$ & $2,008.3$ & 364.4 & $1,422.1$ & $1,739.2$ & $\mathbf{3 1 7 . 1}$ & $1,436,0$ & $1,847,6$ & -411.6 & $1,725.2$ & 2,2,99.7 & -524.5 & $1,565,1$ & $2,305.7$ & $-740,6$ \\
\hline Labor income & 95.7 & 0.0 & 95.7 & 70.4 & 0.0 & 70.4 & 48.1 & 0.0 & 48.1 & 42.3 & 0,0 & 42.3 & 32.3 & 0.0 & 32.3 \\
\hline Investment income & $1,548.4$ & $2,008.5$ & -460.1 & $1,351.7$ & $1,739.2$ & -387.5 & $1,387.9$ & $1,847.6$ & -459.7 & 1682.9 & 2249.7 & -566.8 & 1532.8 & 2305.7 & -772.9 \\
\hline Interest on publis debt & 0.0 & 393.2 & -393.2 & 0.0 & 243.3 & -243.3 & 0.0 & 281.3 & -282.3 & 0.0 & 303.2 & -303.2 & a. & 368.0 & -368.0 \\
\hline Private sector & $1,548.4$ & $1,515.3$ & -65.9 & $1,351.7$ & $1,495.9$ & -144.2 & $1,387.9$ & $1,565.3$ & -177.4 & $1,682.9$ & 1946.5 & -263.6 & $1532 B$ & 1937.7 & -404.9 \\
\hline ZLC & 19.3 & 120.4 & -101.1 & 13.9 & 112.1 & -96.2 & 16.4 & 180.7 & -164.3 & 48.7 & 193.0 & -144.3 & 49.1 & 192.4 & -143.3 \\
\hline Olher & $1,529.1$ & $1,494.9$ & 34.2 & $1,337.8$ & $1,383.8$ & -46.0 & $1,371,5$ & $1,384.6$ & -13.1 & 1634.2 & 1753.5 & -119.3 & 1483.7 & 1745.3 & -261.6 \\
\hline Current transfers & 182.5 & 29.9 & 142.6 & 164.9 & 30.2 & 134.7 & 180.8 & 30.2 & 150.6 & 195.0 & 36,0 & 159.4 & 2027 & 38.5 & 164.2 \\
\hline Official transfers & 77.1 & 9.5 & 67.6 & 59.0 & 10.2 & 48.8 & 71.7 & 10.2 & 61.5 & 79.9 & 11.0 & 68.9 & 83.0 & 12.4 & 70.6 \\
\hline Other & 105.4 & 20.4 & $\mathbf{8 5 . 0}$ & 105.9 & 20.0 & 85.9 & 109.1 & 20.0 & 89.1 & 115.1 & 25.0 & 90.1 & 119.7 & 26.1 & 93.6 \\
\hline Paid by the U.S. Dept. of Definse & 92.6. & 0.0 & 92.6 & 93.9 & 0.0 & 93.9 & 97,4 & 0,0 & 97.4 & 99.2 & 0.0 & 99.2 & 103,3 & 0.0 & 103.3 \\
\hline Privale transfess & 12.8 & 20.4 & -7.6 & 12.0 & 20.0 & $-\mathbf{8 . 0}$ & 11.7 & 20.0 & -8.3 & 15.9 & 25.0 & -9.1 & 16.4 & 26.1 & -9.7 \\
\hline Capital and timmiclal account is & $3,812,0$ & $3,656,0$ & 156,0 & $3,393.8$ & $2,925.8$ & 4680 & $5,915,3$ & 5,483 & $43 ; .3$ & 7,848 \$ & $6,591.1$ & $1,237.4$ & $4,263,6$ & $3,038.2$ & $1,225,4$ \\
\hline Cepltal sccount & 8.5 & 0.0 & 8.5 & 2,5 & 0.0 & 2.5 & tz.7 & 0.0 & 72.7 & 50.3 & 0.0 & $50 . \%$ & 3.0 & 0.0 & 3.0 \\
\hline Official capital transfers & B.5 & 0.0 & 8.5 & 2.5 & 0.0 & 2.5 & 72.7 & 0.0 & 72.7 & 50.9 & 0.0 & 50.9 & 3.0 & 0.0 & 3.0 \\
\hline Prinvate capital transfers & 0.0 & 0.0 & 0.0 & 0.0 & 0.0 & 0.0 & 0.0 & 0.0 & 0.0 & 0.0 & 0.0 & 0.0 & 0.0 & 0.0 & 0.0 \\
\hline
\end{tabular}

CInternational Monetary Fund. Not for Redistribution 
Table 35. Panama: Balance of Payments (Concluded)

(In millians of balboas)

\begin{tabular}{|c|c|c|c|c|c|c|c|c|c|c|c|c|c|c|c|}
\hline & \multicolumn{3}{|c|}{1995} & \multicolumn{3}{|c|}{1996} & \multicolumn{3}{|c|}{1997} & \multicolumn{3}{|c|}{1998} & \multicolumn{3}{|c|}{1999} \\
\hline & Credit & Debil & Balance & Credia & Debit & Balkaco & Credit & Dethit & Balanies & Creditt & Debrit & Balances & Crodit & Debit & Balance \\
\hline Financial acoount & $3,303.5$ & $3,656.4$ & 147.5 & $\mathbf{3 , 3 9 1 . 3}$ & $2,915.8$ & 465.5 & $5,842.6$ & $5,483.0$ & 359.6 & $7,797.6$ & 6,591.1 & $1,206.5$ & $4,260,6$ & $3,1038.2$ & $1,232.4$ \\
\hline Official capital & 155,0 & 223.7 & -68.7 & 186.4 & 294.3 & -108.4 & $\mathbf{1 , 4 5 4 , 3}$ & $2,018.6$ & -564.3 & 690.3 & 895.4 & -165.1 & 690.0 & 665,5 & -35.5 \\
\hline Noufitancial prbic aeclor & 99.7 & 223.7 & -124.0 & 186.4 & 294.8 & -108.4 & $1,454.3$ & $2,018.6$ & -564.3 & 6003 & 851.0 & -160.7 & 630.0 & 663.9 & $=33.9$ \\
\hline Medium- and long-term & 99.7 & 223.7 & -124.0 & 186.4 & 276.8 & -90.4 & $1,440.6$ & $1,222.9$ & 217.7 & 661.6 & 302.3 & 359.3 & 630.0 & 384.3 & 245.7 \\
\hline Released collateral & 0.0 & 0.0 & 0.0 & 0.0 & 0.0 & 0.0 & 13.7 & 0.0 & 13.7 & 0.0 & 0.0 & 0.0 & 0,0 & 0.0 & 0.0 \\
\hline Change in deposits abroad & 0.0 & 0.0 & 0.0 & 0.0 & 18.0 & -16.0 & 0.0 & 639.3 & -639.3 & 28.7 & 36.8 & $-28 . I$ & 0.0 & 279.6 & -279.6 \\
\hline Other & 0.0 & 0.0 & 0.0 & 0.0 & 0.0 & 0.0 & 0.0 & 158.4 & -156.4 & 0.0 & 4\$1,9 & -491.9 & 0,0 & 0.0 & 0,0 \\
\hline Official bank & 55.3 & 0.0 & 55.3 & 0.0 & 0.0 & 0.0 & 0.0 & 0.0 & 0.0 & 0.0 & 4.4 & -4.4 & 0 & 1.6 & -1.6 \\
\hline Privale capital & $3,648.5$ & $3,432.3$ & 216.2 & $3,204,9$ & $2,631,0$ & 573.9 & $4,388,3$ & $3,464.4$ & 923.9 & 7,1073 & $5,735.7$ & $1,371,6$ & $3,670.6$ & $2,372.7$ & $1,257.9$ \\
\hline Direct investnkent & 309.7 & 43.0 & 266.7 & 428.0 & 17.6 & 410.4 & $1,236.4$ & 0.6 & 1,255. B & $1,307,9$ & 101.8 & 1,206.1 & $\$ 70.1$ & $\$ 3.2$ & 516.9 \\
\hline Fanams Canal Commission & 31.4 & 0.3 & 31.2 & 17.7 & 0.0 & 17.7 & 52.9 & 0.6 & 52.3 & 89.1 & 0.1 & 89.0 & 130.9 & .0 .0 & 130.9 \\
\hline Colón Free Zono & 76.7 & 9.7 & 67.0 & 77.9 & 0,0 & 77.9 & 103.8 & 0.0 & 103.8 & 149.0 & 50.5 & 9.5 & 87.5 & 0.0 & 87.8 \\
\hline Othet privale sestax & 110,5 & 15.9 & 94.6 & 162.5 & 17.6 & 144.9 & 914.4 & 0.0 & 914.4 & 1029.8 & 0.0 & $1,029.8$ & 323.3 & 2.9 & 320.4 \\
\hline Bank:a & 91.1 & 17.1 & 74.0 & 169.9 & 0.0 & 169.9 & 185,3 & 0,0 & 185.3 & 40.0 & 51.2 & -11.2 & 28.1 & 50.3 & -22.2 \\
\hline Pordolio brestment & 318.5 & 0.0 & 318.5 & 570.9 & 25.9 & 545.0 & 0.0 & $1,045.4$ & $-1,045.4$ & 533.1 & 99.0 & 434.1 & 5.6 & 543.7 & -538.1 \\
\hline Colón Frec Zoure & 0.2 & 0.0 & 0.2 & 0.0 & 25.8 & -25.8 & 0.0 & 0.8 & -0.8 & 0.0 & 11.1 & -11.1 & 5.6 & 0.0 & 5.6 \\
\hline Banks & 318.1 & 0.0 & 318.1 & 570.9 & 0.0 & 570.9 & 0.0 & $1,044,6$ & $-1,044,6$ & 533.J & 87.9 & 445.2 & 0.0 & 543.7 & -543.7 \\
\hline Othet private sector & 0.2 & 0.0 & 0.2 & 0.0 & 0.1 & -0.1 & 0.0 & 0.0 & 0.0 & & & & & & \\
\hline Other private investment & $3,020.3$ & $3,389.3$ & -369.0 & $2,206.0$ & $2,587.5$ & -381.5 & $3,131,9$ & $2,418.4$ & 713.5 & $5,266.3$ & $\$, 534.9$ & -268.6 & $3,054.9$ & $1,775.8$ & $1,279.1$ \\
\hline Panmana Canal Comminsion & 0.0 & 47.7 & -47.7 & 1.3 & 35.6 & -34.3 & 0.0 & 2.3 & -2.3 & 0.0 & 47.7 & +7.7 & 0.0 & 63.8 & -63.8 \\
\hline Banks & $2,874,4$ & $3,173,5$ & -299.1 & $1,926.6$ & $2,210.4$ & -283.8 & $2,944.1$ & $2,171.4$ & 772.7 & 5108.0 & 5268.5 & -160.5 & 2986.2 & 1509.7 & $1,476.5$ \\
\hline Colón Free Zons & 823 & 141.7 & -59.4 & 230.8 & 149.7 & $\$ 1.1$ & 103.3 & 229.1 & -125.8 & 143.2 & 172.9 & -29.7 & 0.0 & 118.0 & -118.0 \\
\hline Other paivate sector & 63,6 & 26.4 & 37.2 & 47.3 & 191.8 & -144.5 & 84.5 & 15.6 & 68.9 & 15.1 & 45.8 & -30.7 & 68.7 & 84.3 & -15.6 \\
\hline Errors and omissions & $\cdots$ & $\cdots$ & -40.1 & $\cdots$ & $+\cdots$ & 133.0 & $\cdots$ & $\ldots$ & 298.7 & 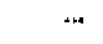 & $\cdots$ & -248.7 & - & - & 61.2 \\
\hline Overall balance & $\cdots$ & $\cdots$ & -253.2 & $m$ & $\cdots$ & 299.1 & $\cdots$ & $\cdots$ & 142.6 & $\cdots$ & -- & -153.5 & $\cdots$ & -- & -90.9 \\
\hline Financing & J69.J & 116.1 & 253.2 & $3,418.7$ & $3,717,8$ & -299.1 & 91.5 & 224.1 & -142.6 & 236.7 & 43.2 & 193.5 & 184.1 & 23.2 & 90.9 \\
\hline Reserves & 12.9 & 116.1 & -103.2 & 75.9 & 295.3 & -219.4 & 45.8 & 156.3 & 111.0 & 217.5 & 13.3 & 204.2 & E1.8 & 23.2 & 58.6 \\
\hline Net foreigs assets of the & & & & & & & & & & & & & & & 0.0 \\
\hline National Bank of Panama & 0.0 & 77.2 & -77.2 & 0.0 & 243.4 & -243.4 & $\theta .0$ & 130.2 & -130.2 & 176.0 & 0.0 & 176.0 & 81.8 & 0.0 & 81.8 \\
\hline Not use of Fand credit & 12.9 & 38.9 & -26.0 & 75.9 & 51.9 & 24.0 & 45.8 & 26.1 & 19.7 & 41.5 & 13.3 & 28.2 & 0.0 & 23.2 & -23.2 \\
\hline Reschatuding & 77.7 & 0.0 & 77.7 & $3,342,8$ & 0.0 & $3,342.8$ & 35.7 & 0.0 & 35.7 & 19.1 & 0.0 & 19,1 & 32.3 & 0.0 & 32.3 \\
\hline Arrear: & 278.7 & 0.0 & 278.7 & 0.0 & $3,422.5$ & $-3,422.5$ & 0.0 & 67.8 & -67.8 & 0.1 & 29.9 & -29.8 & 0.0 & 0.0 & 0.0 \\
\hline \multicolumn{16}{|l|}{ Mermarandum iterns: } \\
\hline Calön Free Zone & & & & & & & & & & & & & & & \\
\hline Commodity rade & $5,346.3$ & $4,682,4$ & 664.1 & $5,082,3$ & $4,218.1$ & 864.2 & $3,825.8$ & $4,892,7$ & 933.1 & 5487.2 & 4959.4 & 527.8 & 4434.9 & 3857.6 & 577.3 \\
\hline Services and income & 19.3 & 572.0 & -552.7 & 13.9 & 483.3 & -469.4 & 16.4 & 624.5 & -608.1 & 48.7 & 470.9 & -422.2 & 49.1 & 428.9 & -379.8 \\
\hline
\end{tabular}

Sources: Ofitce of the Comptroller General; Ministry of Planning and Eeonomic Policy, and Fund ntaff estimnates.

1/ Escluding errors and amissions. 
Table 36. Panama: Summary Balance of Payments

(In millions of bulboss, unless otherwist specified)

\begin{tabular}{|c|c|c|c|c|c|c|c|}
\hline Trade halance & -588.9 & -644.1 & .685 .2 & $-1,361.6$ & $-1,416.5$ & -72.3 .4 & -633.2 \\
\hline Exports & 744.4 & 740.6 & 843.9 & 862.5 & 864.6 & 409.2 & 478.5 \\
\hline Non-oil exports & 598.7 & 573.2 & 682.7 & 735.3 & 712.3 & 338.2 & 366.5 \\
\hline Petroleum exports & 145.7 & 167.4 & 161.2 & 127.2 & 152.3 & 71.0 & 112.0 \\
\hline Non-oil imports & $-1,668.8$ & $-1,836.5$ & $-2,090.6$ & $-2,475.5$ & $-2,505.1$ & -166.3 & -231.5 \\
\hline Colón Free Zone, net. & 664,1 & 864.2 & 933.1 & 527.8 & 577.3 & 262.5 & 272.5 \\
\hline Service balance & 431.6 & 524.6 & 357.8 & 524.9 & 615.4 & 336.4 & 370,8 \\
\hline $\begin{array}{l}\text { Transportation } \\
\text { Of which: }\end{array}$ & 38.9 & 100.4 & 47.8 & 226.1 & 294.9 & 1669 & 176.8 \\
\hline Colón Free Zone & -451.6 & -371.2 & -443.8 & -277.9 & -236.5 & -108.1 & .126 .9 \\
\hline Public sector interest & -393.2 & -243.3 & .282 .3 & -303.2 & -368.0 & .164 .5 & -196.1 \\
\hline $\begin{array}{l}\text { Curtent tranufers (net) } \\
\text { Of which: }\end{array}$ & 152.6 & 134.7 & 150.6 & 159.0 & 164.2 & 85.5 & 85.8 \\
\hline Official transfers (net) & 67.6 & 48.8 & 61.5 & 68.9 & 70.6 & $4[-1$ & 34.7 \\
\hline Capital and financial tecomnt balance & 1560 & 468.0 & 4323 & $1,257.4$ & $1,225.4$ & 957.1 & 716.0 \\
\hline Capital account & 8.5 & 2.5 & 72.7 & 50.9 & 3.0 & 0.0 & 0.0 \\
\hline Grants to nonfinancial public sector & 8.5 & 2.5 & 72.7 & 50.9 & 3.0 & 0.0 & 0.0 \\
\hline Financial account balance $\mathrm{U}$ & 147.5 & 465.5 & 359.6 & $1,206,5$ & $1,222,4$ & 957.1 & 716,0 \\
\hline Public sector (net) & -68.7 & .108 .4 & -564.3 & -165.1 & -35.5 & 466.9 & \\
\hline Nonfinancial public sector & -124.0 & .108 .4 & -564.3 & -160.7 & -33.9 & 469.9 & \\
\hline Drawings & 99.7 & 186,4 & $1,440.6$ & 661.6 & 630.0 & 567.1 & 76.2 \\
\hline Overall butance & -253.2 & 299.0 & 142.7 & -193.5 & -90.9 & 159.0 & 19.1 \\
\hline Financing & 253.2 & -299.1 & -142.6 & 193.5 & 90.9 & -159.0 & -19.1 \\
\hline \multicolumn{8}{|l|}{ Net foroign assets of the National Bank } \\
\hline of Panama (increase -) & -77.1 & -243.4 & -130.2 & 176.1 & 81.8 & -166.9 & -5.6 \\
\hline Net use of Fund credit & -26.0 & 24.0 & 19.7 & 28.2 & .23 .2 & -8.0 & -24.9 \\
\hline Rescheduling & 77.7 & $3,342.9$ & 35.7 & 19.1 & 32.3 & 15.9 & 11.4 \\
\hline Arrears (net) & 278.6 & $-3,422.6$ & -67.8 & -29.9 & 0.0 & 0.0 & 0.0 \\
\hline \multicolumn{8}{|l|}{ Memorandum item: } \\
\hline Cutrent acoount (in percent of GDP) & -4.7 & -3.7 & 6.8 & -13.1 & 14.4 & $\ldots$ & $\ldots$ \\
\hline
\end{tabular}

Sources. Paramanian authorities; and Fund staff estimates. 
Table 37. Panama: Composition of Merchandise Exports

(In millions of balboas, unless otherwise specified)

\begin{tabular}{|c|c|c|c|c|c|c|}
\hline & 1994 & 1995 & 1996 & 1997 & 1998 & 1999 (p) \\
\hline Merchandise exports, f.o.b. I/ & 665.0 & 744.4 & 740.6 & 844.3 & 862.5 & 864.6 \\
\hline Petroleum & 107.4 & 145.8 & 167.4 & 173.8 & 127.2 & 152.3 \\
\hline Nonpetroleum exports, f.o.b. $2 /$ & 539.8 & 577.2 & 566.4 & 647.9 & 703.9 & 707.1 \\
\hline $\begin{array}{l}\text { Bananas } \\
\text { Value } \\
\text { Volume (millions of boxes) } \\
\text { Unit value per box }\end{array}$ & $\begin{array}{r}206.6 \\
41.4 \\
5.0\end{array}$ & $\begin{array}{r}190.4 \\
38.0 \\
5.0\end{array}$ & $\begin{array}{r}184.0 \\
34.8 \\
5.3\end{array}$ & $\begin{array}{r}179.8 \\
33.5 \\
5.4\end{array}$ & $\begin{array}{r}138.7 \\
25.5 \\
5.4\end{array}$ & $\begin{array}{r}182.2 \\
32.7 \\
5.6\end{array}$ \\
\hline $\begin{array}{l}\text { Sugar } \\
\text { Value } \\
\text { Volume (thousands of metric tons) } \\
\text { Unit value per pound }\end{array}$ & $\begin{array}{r}17.1 \\
54.8 \\
0.1\end{array}$ & $\begin{array}{r}18.0 \\
44.2 \\
0.2\end{array}$ & $\begin{array}{r}22.6 \\
46.6 \\
0.2\end{array}$ & $\begin{array}{r}28.7 \\
62.4 \\
0.2\end{array}$ & $\begin{array}{r}25.5 \\
66.2 \\
0.2\end{array}$ & $\begin{array}{r}14.4 \\
33.6 \\
0.2\end{array}$ \\
\hline $\begin{array}{l}\text { Shrimp } \\
\text { Value } \\
\text { Volume (thousands of metric tons) } \\
\text { Unit value per pound }\end{array}$ & $\begin{array}{r}69.5 \\
7.9 \\
4.0\end{array}$ & $\begin{array}{r}82.8 \\
10.4 \\
3.6\end{array}$ & $\begin{array}{r}74.6 \\
11.0 \\
3.1\end{array}$ & $\begin{array}{r}95.7 \\
12.7 \\
3.4\end{array}$ & $\begin{array}{r}136.9 \\
14.1 \\
4.4\end{array}$ & $\begin{array}{r}68.9 \\
7.6 \\
4.1\end{array}$ \\
\hline $\begin{array}{l}\text { Coffee } \\
\text { Value } \\
\text { Volume (thousands of metric tons) } \\
\text { Unit value per pound }\end{array}$ & $\begin{array}{r}14.0 \\
5.3 \\
1.2\end{array}$ & $\begin{array}{r}33.4 \\
10.5 \\
1.4\end{array}$ & $\begin{array}{r}18.8 \\
8.4 \\
1.0\end{array}$ & $\begin{array}{r}22.4 \\
7.5 \\
1.4\end{array}$ & $\begin{array}{r}24.5 \\
8.7 \\
1.3\end{array}$ & $\begin{array}{r}18.5 \\
7.9 \\
1.1\end{array}$ \\
\hline $\begin{array}{l}\text { Fishmeal } \\
\text { Value } \\
\text { Volume (thousands of metric tons) } \\
\text { Unit value per pound }\end{array}$ & $\begin{array}{r}5.1 \\
19.1 \\
0.1\end{array}$ & $\begin{array}{r}5.0 \\
20.5 \\
0.1\end{array}$ & $\begin{array}{l}2.2 \\
7.1 \\
0.1\end{array}$ & $\begin{array}{r}4.5 \\
11.1 \\
0.2\end{array}$ & $\begin{array}{r}6.6 \\
14.3 \\
0.2\end{array}$ & $\begin{array}{r}5.0 \\
18.0 \\
0.1\end{array}$ \\
\hline $\begin{array}{l}\text { Other senfoad } \\
\text { Value } \\
\text { Volume (thousands of metric tons) } \\
\text { Unit value per pound }\end{array}$ & $\begin{array}{r}18.4 \\
6.2 \\
1.4\end{array}$ & $\begin{array}{r}19.5 \\
5.4 \\
1.7\end{array}$ & $\begin{array}{r}22.1 \\
7.2 \\
1.4\end{array}$ & $\begin{array}{r}36.4 \\
13.4 \\
1.2\end{array}$ & $\begin{array}{r}56.4 \\
19.9 \\
1.3\end{array}$ & $\begin{array}{r}58.9 \\
22.2 \\
1.2\end{array}$ \\
\hline $\begin{array}{l}\text { Clothing } \\
\text { Value } \\
\text { Volume (metric tons) } \\
\text { Unit value per pound }\end{array}$ & $\begin{array}{r}20.5 \\
0.6 \\
34.2\end{array}$ & $\begin{array}{r}22.2 \\
0.6 \\
37.0\end{array}$ & $\begin{array}{r}20.1 \\
0.6 \\
33.5\end{array}$ & $\begin{array}{r}24.8 \\
0.7 \\
35.4\end{array}$ & $\begin{array}{r}25.9 \\
0.8 \\
32.4\end{array}$ & $\begin{array}{r}21.9 \\
0.8 \\
27.4\end{array}$ \\
\hline $\begin{array}{l}\text { Other exports } \\
\text { Value }\end{array}$ & 188.6 & 205.9 & 222.0 & 255.6 & 289.4 & 337.3 \\
\hline Balance of payments adjustments for coverag & -19.8 & -21.2 & -26.4 & -13.9 & -13.3 & -46.4 \\
\hline Re-exports & 37.6 & 42.6 & 33.2 & 36.5 & 44.7 & $\$ 1,6$ \\
\hline
\end{tabular}

Sources: Office of the Comptroller General; and Fund staff estimates.

(p) Preliminary

1/ Including re-exports and balance of payments adjustments.

$2 /$ Excluding re-exports and balance of payments adjustments. 


\section{Table 38. Panama: Petroleum Trade}

(In millions of balboas; volumes in millions of barrels; and unit values in balboas per barrel)

\begin{tabular}{|c|c|c|c|c|c|c|}
\hline & 1994 & 1995 & 1996 & 1997 & 1998 & 1999 \\
\hline Net imports & 191.7 & 157.7 & 227.5 & 210.7 & 149.2 & 201.0 \\
\hline $\begin{array}{l}\text { Total imports, f.o.b. } \\
\text { Crude oil }\end{array}$ & 299.1 & 303.5 & 394.9 & 371.9 & 276.4 & 353.3 \\
\hline $\begin{array}{l}\text { Value } \\
\text { From: }\end{array}$ & 118.8 & 135.0 & 289.0 & 262.2 & 170.2 & 287.2 \\
\hline Ectador & 95.3 & 116.6 & 95.8 & 162.0 & 84.7 & 164.0 \\
\hline Venezuela & 14.9 & 18.4 & 147,0 & 49.2 & 63.3 & 56.7 \\
\hline Mexico & 0.0 & 0.0 & 0.0 & 17.6 & 12.0 & 17.6 \\
\hline Other & 8.6 & 0.0 & 46.2 & 33.4 & 10.2 & 48.9 \\
\hline Refired products & 180.3 & 168.5 & 105.9 & 109.7 & 106.2 & 66.1 \\
\hline Refinery & 180.3 & 168.5 & 105.9 & 109.7 & 106.2 & 66.1 \\
\hline Other & 0.0 & 0.0 & 0.0 & 0.0 & 0.0 & 0.0 \\
\hline Total exports, f.o.b. & 107.4 & 145.8 & 167.4 & 161.2 & 127.2 & 152.3 \\
\hline To other countries & 10.5 & 8.7 & 20.5 & 22.3 & 37.3 & 54.3 \\
\hline Bunker oil for ships & 63.0 & 81.7 & 122.0 & 108.3 & 63.0 & 71.3 \\
\hline Fuel for aircraft & 33.9 & 55.4 & 24.9 & 30.6 & 26.9 & 26.7 \\
\hline \multicolumn{7}{|l|}{$\begin{array}{l}\text { Memorandum items: } \\
\text { Crude oil indexes }\end{array}$} \\
\hline Volume & 8.5 & 8.8 & 14.7 & 15.0 & 16.6 & 18.2 \\
\hline Unit value & 14.0 & 15.4 & 20.5 & 17.5 & 11.3 & 15.8 \\
\hline
\end{tabular}

Sources: Office of the Comptroller General; Ministry of Commerce and Industry; and Fund staff estimates. 
Table 39. Panama: Nontraditional Exports and Issue of Tax Credit Certificates

(In millions of balboas)

\begin{tabular}{|c|c|c|c|c|c|c|}
\hline & 1994 & 1995 & 1996 & 1997 & $1998 \mathrm{I} /$ & 1999 \\
\hline Nontraditional exports, f.o.b. 2 / & 82.2 & 100.8 & 129,5 & 125,6 & 175.2 & 183.7 \\
\hline Food & 1.0 & 3.1 & 2.8 & 11.9 & $\ldots$ & $\ldots$ \\
\hline Other agricultural products & 23.8 & 35.4 & 46.2 & 51.3 & $\ldots$ & $\ldots$ \\
\hline Beverages and tobacco & 9.8 & 8.2 & 10.3 & 9.7 & $\ldots$ & $\ldots$ \\
\hline Metals & 0.0 & 0.0 & 0.0 & 0.0 & $\ldots$ & $\ldots$ \\
\hline Mantufactures & 47.6 & 54.2 & 70.2 & 52.7 & $\ldots$ & ... \\
\hline Isspes of tax credit certificates $2 /$ & 12.6 & 13.8 & 19.1 & 18,8 & $\mathbf{2 5 . 3}$ & 34.3 \\
\hline Food & 0.1 & 0.3 & 0.3 & 2.2 & $\ldots$ & \\
\hline Agribusiness & & & & & 2.9 & 5.9 \\
\hline Other agricultural products & 5.4 & 5.2 & 8.5 & 7.9 & & \\
\hline Agricultural products & & & & & 8.6 & 5.6 \\
\hline Beverages and tobacco & 2.3 & 1.0 & 1.5 & 1.5 & $\ldots$ & $\ldots$ \\
\hline Sea products & & & & & 5.9 & 9.4 \\
\hline Manufactures & 4.8 & 7.3 & 8.8 & 7.2 & 7.5 & 13.4 \\
\hline $\begin{array}{l}\text { Ratio of tax eredit certificates } \\
\text { to nontraditional exports (in percent) }\end{array}$ & 15,3 & 13.7 & 14.8 & 14,9 & 14,4 & 18.6 \\
\hline
\end{tabular}

Sources: Panama Trade Development Institute (TPCE) until 1997; Ministry of Cotomerce and Industry in 1998; and Fund staff estimates.

1/ The classification of tax credit certificates for nontraditional exports changed in 1998.

2/ Excludes nontratitional exports not benefiting from tax credit certificates. 
Table 40. Panama: Composition of Merchandise Imports, c.i.f

(Value in miltions of balboas; indices: $1988=100$ )

\begin{tabular}{|c|c|c|c|c|c|c|}
\hline & 1994 & 1995 & 1996 & 1997 & 1998 & 1999 \\
\hline \multicolumn{7}{|l|}{ Food } \\
\hline Value & 211.9 & 230.9 & 267,0 & 269.9 & 326.3 & 342.8 \\
\hline Volume index & 315.4 & 346.9 & 385.1 & 381.2 & $\ldots$ & \\
\hline Unit value index & 72.1 & 71.4 & 74.8 & 76.3 & ... & \\
\hline \multicolumn{7}{|l|}{ Capital goods } \\
\hline Value & 541.9 & 596.3 & 679.6 & 762.9 & 891.3 & 839.4 \\
\hline Volume index & 379.8 & 373.0 & 427.1 & 488.8 & $\ldots$ & \\
\hline Unit value index & 105.6 & 116.7 & 119.2 & 116.5 & $\cdots$ & \\
\hline \multicolumn{7}{|l|}{ Petrolenm } \\
\hline Value & 118.8 & 135.0 & 289.6 & 262.2 & 188.0 & 302.0 \\
\hline Volume index & 125.1 & 129.5 & 216.4 & 220.8 & 244.3 & 267.8 \\
\hline Unit value index & 116.4 & 128.0 & 170.4 & 145.5 & 93.9 & 131.3 \\
\hline \multicolumn{7}{|c|}{$\begin{array}{l}\text { Other consamer and } \\
\text { intermediate goods }\end{array}$} \\
\hline Value & $1,522.8$ & $1,563.4$ & $1,532.8$ & $1,711.4$ & $1,996.1$ & $2,031.5$ \\
\hline Volume index & 405.9 & 386.9 & 386.5 & 423.3 & $\ldots$ & \\
\hline Unit value index & 75.8 & 81.1 & 82.2 & 83.2 & $\ldots$ & \\
\hline Total value & $2,402.1$ & $2,535.3$ & $2,781.1$ & $3,006.4$ & $3,398.3$ & $3,515.7$ \\
\hline
\end{tabular}

Sources: Office of the Comptroller General; and Fund staff estimates. 
Table 41. Panama: Direction of Trade 1/

(In percent)

\begin{tabular}{|c|c|c|c|c|c|c|}
\hline & 1994 & 1995 & 1996 & 1997 & 1998 & $\begin{array}{l}\text { Prel. } \\
1990\end{array}$ \\
\hline Exports, f.o.b. & 100.0 & 100.0 & 100.0 & 100.0 & 100.0 & 100.0 \\
\hline Westem Hemisphere & 61.0 & 66.6 & 73.3 & 73.6 & 68.1 & 70.8 \\
\hline United States & 37.8 & 41.9 & 47.5 & 45.2 & 40.0 & 42.2 \\
\hline Central America and the Caribbean & 19.2 & 19.6 & 19.3 & 21.2 & 20.6 & 21.6 \\
\hline South America & 2.7 & 3.7 & 4.1 & 3.9 & 3.7 & 3.4 \\
\hline Other & 1.3 & 1.4 & 2.4 & 3.3 & 3.8 & 3.6 \\
\hline Europe & 33.9 & 30.7 & 23.0 & 22.6 & 27.0 & 23,0 \\
\hline Belgium and Luxernbourg & 7.0 & 4.8 & 4.2 & 5.4 & 4.3 & 4.4 \\
\hline Germany & 12.8 & 12.4 & 4.5 & 3.1 & 3.4 & 10.7 \\
\hline Italy & 1.8 & 1.1 & 1.0 & 0.7 & 2,7 & 4.1 \\
\hline Sweden & 9.0 & 4.8 & 10.2 & 8.4 & 7.2 & 1.1 \\
\hline Other & 3.3 & 7.6 & 3.1 & 5.0 & 9.4 & 2.7 \\
\hline Other cauntries & 5.1 & 2.7 & 3.7 & 3,8 & 4.9 & 6.2 \\
\hline \multicolumn{7}{|l|}{ Of which: } \\
\hline Exports through the Colón Free Zone & 1.3 & 1.1 & 2.0 & 2.0 & 1.9 & 1.9 \\
\hline Imports, c.i.f. $2 /$ & 100.0 & 100.0 & 100.0 & 100.0 & 100.0 & 100,0 \\
\hline Western Hemisphere & 60.9 & 63.7 & 65.7 & 64.0 & 62.2 & 61.8 \\
\hline United States & 38.0 & 39.4 & 37.4 & 36.7 & 39.5 & 35.8 \\
\hline Mexico & 2.0 & 3.3 & 3.8 & 4.9 & 4.8 & 4.4 \\
\hline Central America and the Caribbean & 9.1 & 7.6 & 7.1 & 7.4 & 7.5 & 8.4 \\
\hline Costa Rica & 2.8 & 2.9 & 2.7 & 2.9 & 3.0 & 3.3 \\
\hline Trinidad and Tobago & 0.7 & 0.4 & 0.3 & 0.5 & 0.2 & 1.2 \\
\hline Other & 5.6 & 4.3 & 4.1 & 4.0 & 4.3 & 3.9 \\
\hline South Americg & 11.8 & 13.4 & 17.4 & 15.0 & 10.4 & 13.2 \\
\hline Venezuela & 2.2 & 3.2 & 7.2 & 3.9 & 3.5 & 2.9 \\
\hline Ecuador & 4.4 & 5.3 & 3.7 & 5.6 & 2.9 & 5.3 \\
\hline Brazil & 1.7 & 1.4 & I.1 & 10 & 0,8 & 1.0 \\
\hline Other & 3.5 & 3.5 & 5.4 & 4.5 & 3.2 & 4.0 \\
\hline Europe & 9.6 & 8.8 & 8.3 & 8.8 & 8.3 & 9.7 \\
\hline Germany & 1.8 & 1.9 & 1.7 & 1.3 & 1.3 & 1.4 \\
\hline France & 0.6 & 0.6 & 0.5 & 1.5 & 0.9 & 0.7 \\
\hline Spain & 1.0 & 1.2 & 1.0 & 1.3 & 1.3 & 1.5 \\
\hline Italy & 1.4 & 0.9 & 0.8 & 0.7 & 0.6 & 0.7 \\
\hline Netherlands & 1.8 & 1.3 & 0.9 & 0.6 & 0.7 & 0.6 \\
\hline United Kingdom & 0.6 & 0.6 & 0.6 & 0.8 & 1.2 & 1.0 \\
\hline Other & 2.4 & 2.3 & 2.8 & 2.6 & 2.3 & 3.8 \\
\hline \multicolumn{7}{|l|}{$\begin{array}{l}\text { Other countries } \\
\text { Of which: }\end{array}$} \\
\hline Imports from the Colon Free Zone & 15.3 & 14.3 & 13.6 & 13.9 & 12.8 & 12.5 \\
\hline
\end{tabular}

Sources: Office of the Comptroller General; and Fund staff estimates.

1/ Based on Customs data.

2/ Excludes sales of bunker oil. 
Table 42. Panama: Net Services Receipts

(In millions of balboas)

\begin{tabular}{|c|c|c|c|c|c|}
\hline & 1995 & 1996 & 1997 & 1998 & 1999 \\
\hline Total service receipts (net) & 431.6 & 524.6 & 357.8 & $\mathbf{5 2 4 . 9}$ & 615,4 \\
\hline Transportation & 38.9 & 100.4 & 47.8 & 226.1 & 294.9 \\
\hline Freight and insurance & -703.0 & -622.5 & -731.9 & -595.0 & -542.2 \\
\hline Colón Free Zone & -468.3 & -385.2 & -460.0 & -277.9 & -236.5 \\
\hline Other & -234.7 & -237.3 & -271.9 & -317.1 & -305.7 \\
\hline Canal receipts, net & 585.5 & 598.2 & 633.0 & 689.6 & 692.9 \\
\hline Other & 156.4 & 124.7 & 146.7 & 131.5 & 144.2 \\
\hline Travel & 188.7 & 219.6 & 210.4 & 202.6 & 202.7 \\
\hline Government & -20.7 & -18.4 & -41.7 & 4.3 & -8.8 \\
\hline \multicolumn{6}{|l|}{ Purchases by the U.S. } \\
\hline Department of Defense & 197.3 & 177.7 & 180.9 & 109.1 & 74.9 \\
\hline Other services (net) & 27.4 & 45.3 & -39.6 & -17.2 & 51.7 \\
\hline Total income receipts (net) & -364.4 & -317.1 & -411.6 & -524.5 & -740.6 \\
\hline $\begin{array}{l}\text { Investment income, net } \\
\text { Of which: }\end{array}$ & $-460,1$ & -387.5 & -459.7 & -566.8 & \\
\hline Interest on the public debt & -393.2 & -243.3 & -282.3 & -301.9 & -368.0 \\
\hline Colón Free Zone & -102.9 & -102.6 & -170.2 & -144.3 & -143.3 \\
\hline \multicolumn{6}{|l|}{ Wages paid by the U.S. } \\
\hline Department of Defense & 95.7 & 70.4 & 48.1 & 42.3 & 32.3 \\
\hline
\end{tabular}

Sources: Office of the Accountant General; and Fund staff estimates. 
Table 43. Panama: Operations of the Colón Free Zone

(In millions of balboas)

\begin{tabular}{|c|c|c|c|c|c|c|}
\hline & 1994 & 1995 & 1996 & 1997 & 1998 & $\begin{array}{l}\text { Prel. } \\
1999\end{array}$ \\
\hline Imports $1 /$ & $4,927.4$ & $5,160.5$ & $4,623.7$ & $5,389.6$ & $5,211.9$ & $4,038,0$ \\
\hline Textiles and clothing & $1,310.7$ & $1,255.2$ & 973.0 & $1,200.0$ & $1,080.0$ & 910.0 \\
\hline Beverages and tobacco & 120.7 & 119.7 & 176.1 & 207.8 & 150.3 & 119.4 \\
\hline Chemical products & 413,1 & 448.7 & 496,1 & 577,7 & 635.3 & 641.0 \\
\hline Instruments & 616.9 & 416.2 & 317.6 & 340.9 & 304.4 & 278,8 \\
\hline Machinery and transpor goods & $1,457.2$ & $1,783.7$ & $1,502.4$ & $1,654.8$ & & \\
\hline Other & $1,008.8$ & $1,137.0$ & $1,158,5$ & $1,408.4$ & $3,041.9$ & $2,088.8$ \\
\hline Exports, f.o.b. 1/ & $5,756.7$ & $5,731.4$ & $5,491.7$ & $6,276.0$ & $5,985.2$ & $4,795.7$ \\
\hline Textiles and clothing & $1,478.7$ & $1,339.4$ & $1,177.2$ & $1,384.2$ & 1,2196 & $1,069.3$ \\
\hline Beverages and tobacco & 143.1 & 142.2 & 183.1 & 218.0 & 188.7 & 155.7 \\
\hline Chemical products & 595.4 & 644.7 & 675.6 & 770.5 & 874.1 & 866.8 \\
\hline Instruments & 735,3 & 457.7 & 388.2 & 373.8 & 439.5 & 361.2 \\
\hline Machinery and transport goods & $1,666.5$ & $1,896.3$ & $1,803.4$ & $1,960.2$ & & \\
\hline Other & $1,137.7$ & $1,251.1$ & $1,264.2$ & $1,569.3$ & $3,263.3$ & $2,342.7$ \\
\hline \multicolumn{7}{|l|}{ Memorandum item: } \\
\hline $\begin{array}{l}\text { Number of Panamanians employ } \\
\text { in Colón Free Zone } 2 /\end{array}$ & 12,674 & 13,421 & 12,152 & 13,639 & 14,200 & 14,400 \\
\hline
\end{tabular}

Sources: Office of the Comptroller General; Administration of the Colón Free Zone; and Fund staff estimates.

1/ Excludes balance of payments adjustments.

2/ Average for the year. 
Table 44. Panama: Canal Statistics

\begin{tabular}{|c|c|c|c|c|c|c|c|}
\hline \multirow[b]{3}{*}{$\begin{array}{l}\text { Fiscal year } \\
\text { Ended } \\
\text { Sep. } 30 \\
\end{array}$} & \multirow{2}{*}{\multicolumn{4}{|c|}{ Total Traffic }} & \multicolumn{3}{|c|}{ Traffic Assessed Toll on Net Tonnage Basis 1/ } \\
\hline & & & & & \multirow{2}{*}{$\begin{array}{c}\text { Number } \\
\text { of } \\
\text { Transits } \\
\text { (In thousands) } \\
\end{array}$} & \multirow{2}{*}{$\begin{array}{c}\text { Net Toruage } 21 \\
\text { (In millions } \\
\text { of p.c. } \\
\text { net tons) } \\
\end{array}$} & \multirow{2}{*}{$\begin{array}{c}\text { Average Tonnage } \\
\text { per transit } \\
\text { (In thousands of } \\
\text { p.c. net tons) }\end{array}$} \\
\hline & $\begin{array}{l}\text { Number of } \\
\text { Transits } \\
\text { (In thousands) }\end{array}$ & $\begin{array}{c}\text { Tolls } \\
\text { (In millions } \\
\text { of baltogas) }\end{array}$ & $\begin{array}{l}\text { Cargo Tonnage } \\
\text { (In millions } \\
\text { of long tons) }\end{array}$ & $\begin{array}{l}\text { Average Toll } \\
\text { (balboa per } \\
\text { long ton) }\end{array}$ & & & \\
\hline \multicolumn{8}{|c|}{ Total traffic } \\
\hline 1994 & 14.03 & 419.22 & 170.8 & 2.45 & 13.67 & 195.2 & 14.28 \\
\hline 1995 & 15.14 & 462.75 & 190.4 & 2.43 & 14.76 & 216.3 & 14.65 \\
\hline 1996 & 15.19 & 486.69 & 198.5 & 2.45 & 14.87 & 228.3 & 15.35 \\
\hline 1997 & 14.75 & 493.58 & 189.9 & 2.60 & 14.46 & 217.5 & 15.04 \\
\hline 1998 & 14.24 & 545.74 & 192.2 & 2.84 & 14.08 & 222.6 & 15.81 \\
\hline 1999 & 14.34 & 568.91 & 196.0 & 2.90 & 14.07 & 227.6 & 16.18 \\
\hline \multicolumn{8}{|c|}{$\begin{array}{l}\text { Of which: } \\
\text { Commercial } \\
\text { Ooean traffic 3/ }\end{array}$} \\
\hline 1994 & 12.48 & 419.06 & 170.8 & 2.45 & 12.34 & 195.2 & 15.82 \\
\hline 1995 & 13.63 & 462.58 & 190.4 & 2.43 & 13.47 & 216.2 & 16.05 \\
\hline 1996 & 13.72 & 486.54 & 198.5 & 2.45 & 13.57 & 228.2 & 16.82 \\
\hline 1997 & 13.16 & 493.39 & 189.9 & 2.60 & 13.04 & 217.5 & 16.68 \\
\hline 1998 & 13.02 & 545.43 & 192.2 & 2.84 & 12.93 & 222.5 & 17,21 \\
\hline 1999 & 13.14 & 568.1 & 196.0 & 2.90 & 12.99 & 227.4 & 17.51 \\
\hline
\end{tabular}

Sources: Panama Canal Commission; and Fund staff estimates.

1/ Traffic tolls not assessed on net tonnage basis are assessed on displacement-tonnage basis.

2/ One Panama Canal (p.c) net ton equals 100 cubic feet space. Noncommercial ocean traffic is mainly U.S. Government traffic.

$3 /$ Ocean traffic incluđes ships of 300 p.c. net tons and over. 
Table 45. Panama: Principal Commodities Shipped Through the Canal

(In thousands of long tons)

\begin{tabular}{|c|c|c|c|c|c|c|c|c|c|c|c|c|}
\hline \multirow{2}{*}{$\begin{array}{l}\text { Fiscal Year } \\
\text { Ended September } 30\end{array}$} & \multicolumn{6}{|c|}{ Atlantic to Pacific } & \multicolumn{6}{|c|}{ Pacific to Atlantic } \\
\hline & 1994 & 1995 & 1996 & 1997 & 1998 & 1999 & $\overline{1994}$ & 1995 & 1996 & 1997 & 1998 & 1999 \\
\hline Total & 102,595 & 120,845 & 124,205 & 115,547 & 110,246 & 118,709 & 67,943 & 69,458 & 73,861 & 74,233 & 81,847 & 77,116 \\
\hline Agricultural & 31,531 & 43,684 & 41,420 & 34,592 & 34,801 & 42,839 & 13,075 & 12,172 & 13,124 & 12,580 & 12,094 & 12,810 \\
\hline Canned and refrigerated foods & 1,113 & 1,218 & 1,230 & 1,213 & 1,118 & 1,385 & 4,883 & 5,645 & 5,717 & 5,761 & 5,258 & 5,673 \\
\hline Grains & 29,547 & 41,118 & 39,279 & 32,399 & 32,901 & 40,653 & 4,520 & 2,956 & 3,155 & 2,912 & 2,892 & 3,524 \\
\hline Other & 871 & 1,348 & 911 & 980 & 782 & 801 & 3,672 & 3,571 & 4,252 & 3,907 & 3,944 & 3,613 \\
\hline Mining products & 21,427 & 21,960 & 22,022 & 20,596 & 18,424 & 18,650 & 19,233 & 21,458 & 23,796 & 25,152 & 24,478 & 20,299 \\
\hline Minerals & 186 & 159 & 130 & 101 & 70 & 150 & 5,602 & 5,268 & 6,842 & 7,126 & 6,224 & 5,127 \\
\hline Phosphates and fertilizers & 13,603 & 14,451 & 14,805 & 13,888 & 13,391 & 13,633 & 1,834 & 1,457 & 1,135 & 1,193 & 1,144 & 837 \\
\hline Ores and metals & 3,766 & 4,128 & 3,641 & 3,776 & 2,920 & 2,232 & 6,330 & 6,633 & 7,882 & 8,412 & 9,573 & 7,710 \\
\hline Coke and coal & 3,872 & 3,222 & 3,446 & 2,831 & 2,043 & 2,635 & 5,467 & 8,100 & 7,937 & 8,421 & 7,537 & 6,625 \\
\hline \multicolumn{13}{|l|}{ Crude oil and petroleum } \\
\hline products $1 /$ & 14,312 & 15,944 & 19,245 & 19,151 & 18,527 & 20,038 & 12,650 & 11,516 & 13,541 & 11,591 & 12,195 & 8,591 \\
\hline Chemicals & 8,258 & 8,557 & 9,555 & 8,860 & 7,299 & 8,311 & 1,451 & 1,557 & 1,820 & 1,502 & 1,990 & 2,812 \\
\hline Manufactures of iron and steel & 3,746 & 4,898 & 4,705 & 3,911 & 4,462 & 3,393 & 4,101 & 4,276 & 3,640 & 4,249 & 8,846 & 8,440 \\
\hline Machinery and equipment & 692 & 734 & 809 & 787 & 723 & 622 & 1,357 & 1,408 & 1,125 & 1,272 & 1,443 & 1,689 \\
\hline Lumber and wood products & 5,297 & 5,928 & 7,238 & 7,146 & 5,689 & 5,950 & 4,165 & 4,784 & 3,792 & 4,060 & 3,747 & 3,683 \\
\hline Miscellaneous & 17,332 & 19,140 & 19,211 & 20,504 & 20,321 & 18906 & 11,911 & 12,287 & 13,023 & 13,827 & 17,054 & 18,792 \\
\hline
\end{tabular}

Sources: Panama Canal Commission; and Fund staff estimates.

1/ Includes crude oil, diesel oil, fuel oil, gasoline, jet fuel, liquified natural gas, kerosene, and asphalt. 
Table 46. Panama: Travel Receipts and Expenditure, and Number of Visitors

\begin{tabular}{|c|c|c|c|c|c|c|}
\hline & 1994 & 1995 & 1996 & 1997 & 1998 & 1999 \\
\hline \multicolumn{7}{|c|}{ (In millions of balboas) } \\
\hline Net travel receipts & 139.4 & 188.7 & 219.6 & 211.7 & 202,6 & 202.7 \\
\hline Travel receipts & 261.6 & 309.4 & 359.9 & 376.8 & 378.8 & 387.2 \\
\hline Tourists & 138.1 & 157.6 & 198.8 & 154.8 & 149.8 & 169.0 \\
\hline \multicolumn{7}{|l|}{ Business, official, } \\
\hline and education related travel & 59.7 & 61.3 & 53.1 & 88.3 & 93.5 & 95.7 \\
\hline Travelers in transit and others & 638 & 90.5 & 108.0 & 133.7 & 135.5 & 122.5 \\
\hline \multicolumn{7}{|l|}{ Expenditure of } \\
\hline Panamanians traveling abroad & -122.2 & -120.7 & -140.3 & -165.1 & -176.2 & -184.5 \\
\hline \multicolumn{7}{|c|}{ (In thousands) } \\
\hline Visitors $1 /$ & 351.2 & 380.8 & 431.8 & 410.5 & 414.5 & 445.0 \\
\hline Tourists & 241.3 & 268.5 & 340,3 & 261,4 & 252,3 & 280.8 \\
\hline $\begin{array}{l}\text { Business, official, } \\
\text { and education related travel }\end{array}$ & 109.9 & 112.3 & 91.5 & 149.1 & 162.2 & 164,2 \\
\hline Travelers in transit $2 /$ & 283.6 & 394.0 & 460.6 & 576.7 & 565.0 & 502.0 \\
\hline
\end{tabular}

Sources: Office of the Comptrolier General; and Fund staff estimates.

1/ Entries into Panama excluding residents, immigrants, and persons in transit or whose destination is the Canal area.

2/ Nonresidents who spent less than 48 hours in Panama. 
Table 47. Panama: Public Sector: External Debt and Debt Service

(In millions of bolbons; stocks at end of period) $1 /$

\begin{tabular}{|c|c|c|c|c|c|c|}
\hline & 1995 & 1996 & 1997 & 1998 & 1999 & $\begin{aligned} \text { Jar.-Sep. } \\
2000\end{aligned}$ \\
\hline \multicolumn{7}{|l|}{ Stock of external debt } \\
\hline Total & $5,966 . \bar{I}$ & $5,127,2$ & $5,080.3$ & $5,415,8$ & $5,633,0$ & $5,697.9$ \\
\hline Multilateral & 764.5 & 806.0 & 933.4 & $1,146.5$ & $1,166.8$ & $1,102.2$ \\
\hline $\mathrm{IMF}$ & 110.6 & 130.9 & 142.2 & 170.4 & 148.7 & 103.3 \\
\hline IBRD & 182.5 & 198.7 & 229.6 & 288.0 & 297.5 & 282.1 \\
\hline $\mathrm{IDB}$ & 462.4 & 469.7 & 554.7 & 673.8 & 698.8 & 693.1 \\
\hline IFAD & 9.0 & 6.7 & 6.9 & 14.3 & 21.8 & 23.7 \\
\hline Bilateral & 858.0 & 562.0 & 524.7 & 523.5 & 500.4 & 446.1 \\
\hline Paris Chub 2/ & 400.2 & 385.4 & 333.1 & 313.2 & 299.4 & 264.8 \\
\hline Venezuela, Mexica & 299.2 & 0.0 & 0.0 & 0.0 & 0.0 & 0.0 \\
\hline Support group & 83.3 & 101.3 & 117.9 & 142.6 & 134.8 & 121.2 \\
\hline Taiwan 3/ & 75.3 & 75.3 & 73.7 & 67.7 & 56.2 & 60.1 \\
\hline Commercial & $4,299.6$ & $3,724.2$ & $3,593.3$ & $3,745.2$ & $3,965.6$ & $4,149.6$ \\
\hline $\begin{array}{l}\text { Medium- and long-term debt } \\
\text { Of which: }\end{array}$ & $4,193.6$ & $3,724.2$ & $3,593.3$ & $3,745.2$ & $3,965.6$ & $4,149.6$ \\
\hline Brady bonds & 3761.1 & $3,285.2$ & $2,027.9$ & $1,965.0$ & $1,781.6$ & $1,648.1$ \\
\hline Other bonds & 432.5 & 365.4 & $1,498.7$ & $1,762.5$ & $2,165.4$ & $2,483.2$ \\
\hline Short-term & 106.0 & 0.0 & 0.0 & 0.0 & 0.0 & 0.0 \\
\hline Suppliers 4 & 44.0 & 35.t & 28.9 & 0.6 & 0.2 & 0.0 \\
\hline \multicolumn{7}{|l|}{ Debt-service $5 t$} \\
\hline $\begin{array}{l}\text { Total } \\
\text { Princinal }\end{array}$ & 654.8 & 482.2 & $1,511,4$ & 663.2 & 784.5 & $\begin{array}{l}682.5 \\
332.3\end{array}$ \\
\hline $\begin{array}{l}\text { Principal } \\
\text { Interest }\end{array}$ & $\begin{array}{l}262.6 \\
392.2\end{array}$ & $\begin{array}{l}236.0 \\
246.2\end{array}$ & $\begin{array}{r}1,229.1 \\
282.3\end{array}$ & $\begin{array}{l}357.3 \\
305.9\end{array}$ & $\begin{array}{l}414.0 \\
370.5\end{array}$ & $\begin{array}{l}332.3 \\
350.2\end{array}$ \\
\hline Multilsteral & 171.5 & 170.2 & 139.2 & 119.8 & 141.6 & 142.0 \\
\hline Principal & 125.3 & 124.0 & 98.7 & 72.3 & 75.6 & 82.7 \\
\hline Interest & 46.2 & 46.2 & 44.8 & 47.5 & 66.0 & 59.3 \\
\hline Bilateral & 69.8 & 66.5 & 82.5 & 113.9 & 96.5 & 86.4 \\
\hline Principal 6/ & 31.2 & 30.4 & 57.2 & 89.0 & 71.1 & 66.7 \\
\hline Interest & 40.6 & 38.8 & 28.0 & 24.9 & 25.4 & 19.7 \\
\hline Commercial & 397.7 & 230.9 & $1,280.2$ & 423.2 & 546.0 & 453.9 \\
\hline Principal 7/ & 94.1 & 72.5 & $1,068.1$ & 191.6 & 266.9 & 182.6 \\
\hline $\begin{array}{l}\text { Interest } \\
\text { Of which: }\end{array}$ & 300.7 & 158.4 & 246.8 & 231.6 & 279.1 & 271.2 \\
\hline Short-term $8 /$ & 2.9 & 0.0 & 0.0 & 0.0 & 0.0 & 0.0 \\
\hline Suppliers & 16.7 & 11.8 & 7.9 & 6.3 & 0.4 & 0.2 \\
\hline Principal & 12.1 & 9.1 & 5.2 & 4.4 & 0.4 & 0.2 \\
\hline Interest & 4,6 & 2.7 & 2.7 & 1.9 & 0.0 & 0.0 \\
\hline
\end{tabular}

Sources: Ministry of Planning and Economic Policy; IBRD; IDB; and Fund staff estimates.

$1 /$ Iricludes accrued interest arrears.

$2 /$ Irclndes insured suppliers' credit.

3/ Debt of the National Bank of Panama.

4/ Noninsared suppliers' credits only.

5/ Includes imputed charges on overdue obligations.

$6 /$ Increase in 1998 is due to payment of arrears to Libyan Arab Foreign Bark.

$7 /$ Increases in 1997 and 1998 are due to repurchases of Brady bonds.

$8 /$ Consists of interest on credit lines and on money facilities of the National Bank; the latter is excluded from interest af the nonfinancial public sector. 
Table 48. Panama: External Public Debt Indicators

(In percent)

\begin{tabular}{|c|c|c|c|c|c|}
\hline & 1995 & 1996 & 1997 & 1998 & 1999 \\
\hline \multicolumn{6}{|l|}{ Debt-service ratios $1 /$} \\
\hline Principal due & 17.7 & 15.2 & 73.6 & 20.2 & 21.3 \\
\hline Interest due & 26.5 & 15.9 & 16.9 & 17.3 & 18.9 \\
\hline In terms of GDP & 8.3 & 5.9 & 17.5 & 7.3 & 8.2 \\
\hline Principal due & 3.3 & 2,9 & 14,2 & 3,9 & 4.3 \\
\hline Interest due & 5.0 & 3.0 & 3.3 & 3.3 & 3.9 \\
\hline In terms of exports of goods and services & 22.4 & 15.2 & 44.1 & 21.4 & 24.7 \\
\hline Principal due & 9.0 & 7.5 & 35.9 & 11.6 & 13.1 \\
\hline Interest due & 13.4 & 7,8 & 8.2 & 9.8 & 11.6 \\
\hline \multicolumn{6}{|l|}{ External debt ratios } \\
\hline External debt in terms of GDP 3 / & 75.5 & 62.9 & 58.7 & 59.2 & 59.0 \\
\hline $\begin{array}{l}\text { Multilateral and bilateral } 4 / \\
\text { Of which: }\end{array}$ & 20.5 & 16.8 & 16.8 & 18.3 & 17.5 \\
\hline IMF & 1.4 & 16 & 1.6 & 1.9 & 1.6 \\
\hline Other $5 /$ & 54.9 & 46.1 & 41.8 & 41.0 & 41.6 \\
\hline Effective interest rates on total debt $6 /$ & 6.6 & 4.8 & 5.6 & 5.6 & 6.6 \\
\hline \multicolumn{6}{|l|}{ Memorandum item: } \\
\hline Six-month LIBOR (year average) & 6.1 & 5.6 & 5.8 & 5.5 & 5.3 \\
\hline
\end{tabular}

Sources: Office of the Comptroller General; National Bank of Parlama; Ministry of Planning and Economic Policy, and Fund staff estimates.

1/ Debt-service ratios exclude payments due on short-term debt, but include payments due to the IMF.

2/ Central government receipts include transfers from the rest of the public sector and exclude grants.

3/ Including interest arrears and short-tem debt.

4/ Includes insured suppliers' credits.

5/ Includes nonguaranteed suppliers' credits.

6/ Interest rate on average debt outstanding during the period. Rates are affected by variations in exchange rates. 
Table 49. Panama: Operations on Medium- and Long-Term External Debt of the Nonfinancial Public Sector Classified by Creditor 1/

(In millions of balboas)

\begin{tabular}{|c|c|c|c|c|c|c|c|}
\hline & \multicolumn{6}{|c|}{ Operations in 1994} & \multirow[b]{2}{*}{$\begin{array}{c}\text { Out- } \\
\text { starlding } \\
12 / 31 / 94\end{array}$} \\
\hline & $\begin{array}{c}\text { Out- } \\
\text { standing } \\
12 / 31 / 93\end{array}$ & Drawings & $\begin{array}{l}\text { Amort- } \\
\text { ization } \\
\text { Due. }\end{array}$ & $\begin{array}{l}\text { Interest } \\
\text { Due }\end{array}$ & Payments & $\begin{array}{l}\text { Adjust- } \\
\text { ments } 2 r\end{array}$ & \\
\hline Total & $5,213.9$ & 52.3 & 270.3 & 343.6 & 286.8 & 68.4 & $5,391.4$ \\
\hline Multilateral & 767.3 & 30.5 & 95.5 & 51.2 & 146.7 & 30.5 & 733.0 \\
\hline RFF & 115.7 & 14.0 & 1.2 & 7.6 & 8.8 & 4.2 & 132.8 \\
\hline BRD & 244.3 & 1.4 & $\$ 3.5$ & 18.1 & 71.6 & 14]$. & 206.3 \\
\hline IDB & 397.3 & 14.6 & 39.4 & 24.7 & 64.1 & 12.3 & 384.8 \\
\hline IFAD & 10.0 & 0.5 & 1.4 & 0.8 & 2.2 & -0.1 & 9.1 \\
\hline Bilateral & 757.7 & 41.8 & 49.7 & 41.4 & 62.1 & 11.8 & 790.6 \\
\hline Paris Club $3 /$ & 417.7 & 1.8 & 17.6 & 20.8 & 38.4 & 6.5 & 408.4 \\
\hline Venezoela and Mexico & 262.1 & 0.0 & 12.1 & 16.9 & 0.0 & -1.8 & 277.2 \\
\hline Support group & 77.9 & 20.0 & 20.0 & 3.2 & 23.2 & 7.1 & 85.0 \\
\hline Taiwan 4 & 0.0 & 20.0 & 0.0 & 0.5 & 0.5 & 0.0 & 20.0 \\
\hline $\begin{array}{l}\text { Commercial } \\
\text { Of which: }\end{array}$ & $3,613.4$ & 0.0 & 116.3 & 251.8 & 65.6 & 30.5 & $3,830.1$ \\
\hline Brady bonds & $3,144.0$ & 0.0 & 104.4 & 228.5 & 6.0 & 30.5 & $3,397.0$ \\
\hline Other bonds & 469.4 & 0.0 & 11.9 & 23.3 & 59.6 & 0.0 & 433.1 \\
\hline \multirow[t]{3}{*}{ Suppliers $5 /$} & 75.5 & 0.0 & 8.9 & 3.4 & 12.8 & -8.3 & 57.8 \\
\hline & \multicolumn{6}{|c|}{ Operations in 1995} & \multirow[b]{2}{*}{$\begin{array}{c}\text { Out- } \\
\text { standing } \\
12 / 31 / 95\end{array}$} \\
\hline & $\begin{array}{c}\text { Out= } \\
\text { standing } \\
12 / 31 / 94\end{array}$ & Drawings & $\begin{array}{l}\text { Amort- } \\
\text { ization } \\
\text { Due }\end{array}$ & $\begin{array}{c}\text { Interest } \\
\text { Due }\end{array}$ & Payments & $\begin{array}{l}\text { Adjust- } \\
\text { ments 2/ }\end{array}$ & \\
\hline Total & $5,391.4$ & 112.6 & 262.6 & 390.3 & 288.9 & 179.4 & $5,784.8$ \\
\hline Multiłateral & 733.0 & 107.9 & 125.3 & 46.2 & 171.5 & 49.0 & 764.5 \\
\hline IMF & 132.8 & 12.9 & 38.9 & 8.7 & 47.7 & 3.9 & 110.6 \\
\hline BBRD & 206.3 & 2.8 & 43.1 & 15.5 & 58.6 & 16.5 & 182.5 \\
\hline IDB & 384.8 & 90.9 & 41.8 & $2] .3$ & 63.0 & 28.4 & 462.4 \\
\hline IFAD and $C A F$ & 9.1 & 1.3 & 1.5 & 0.7 & 2.3 & 0.2 & 9.0 \\
\hline Bilateral & 770.6 & 4.7 & 31.2 & 38.7 & 44.8 & 13.6 & 782.7 \\
\hline Paris Club 3/ & 408.4 & 4.7 & 18.5 & 22.3 & 40.9 & 5.7 & 400.2 \\
\hline Venezuela and Mexico & 277.2 & 0.0 & 12.6 & 12.4 & 0.0 & 9.6 & 299.2 \\
\hline Suppoit group & 85.0 & 0.0 & 0.0 & 3.2 & 3.2 & -1.7 & 83.3 \\
\hline Taiwan 4/ & 20.0 & 55.3 & 0.0 & 1.9 & 1.9 & 0.0 & 75.3 \\
\hline Commercial & $3,830.1$ & 0.0 & 94.1 & 300.7 & 55.9 & 118.5 & $4,193.6$ \\
\hline Of which: & $3,397.0$ & 0.0 & 93.6 & 269.8 & 24.4 & 118.7 & $3,761.1$ \\
\hline \multicolumn{8}{|l|}{ Brady bonds } \\
\hline Other bonds & 433.1 & 0.0 & 0.5 & 31.0 & 31.4 & -0.2 & 432.5 \\
\hline Suppliers 5/ & 57.8 & 0.0 & 12.1 & 4.6 & 16.7 & -1.7 & 44.0 \\
\hline
\end{tabular}


Table 49. Panama: Operations on Medium- and Long-Term External Debt of the Nonfinancial Classified by Creditor (Continued) $1 /$

\begin{tabular}{|c|c|c|c|c|c|c|c|}
\hline \multicolumn{8}{|c|}{ (In millions of balboas) } \\
\hline & \multirow[b]{2}{*}{$\begin{array}{c}\text { Out- } \\
\text { standing } \\
12 / 31 / 95 \\
\end{array}$} & \multicolumn{5}{|c|}{ Operations in 1996} & \multirow[b]{2}{*}{$\begin{array}{c}\text { Out- } \\
\text { standing } \\
12 / 31 / 96\end{array}$} \\
\hline & & Drawings & $\begin{array}{l}\text { Amont- } \\
\text { ization } \\
\text { Due }\end{array}$ & $\begin{array}{l}\text { Interest } \\
\text { Due }\end{array}$ & Payments & $\begin{array}{l}\text { Adjust- } \\
\text { ments 2/ }\end{array}$ & \\
\hline Total & $5,860.1$ & 262.3 & 238.5 & 246.0 & 662.4 & -578.8 & $5,127.2$ \\
\hline Multilateral & 764.5 & 234.5 & 124.0 & 46.2 & 170.2 & -69.0 & 806.0 \\
\hline $\mathbb{I M F}$ & 110.6 & 75.9 & $\$ 1.9$ & 6.5 & 58.5 & -3.6 & 130.9 \\
\hline IRRD & 182.5 & 68.6 & 31.4 & 12.5 & 43.9 & -21.0 & 198.7 \\
\hline $\mathrm{DB}$ & 462.4 & 90.0 & 39.0 & 26.4 & 65.3 & -43.8 & 469.7 \\
\hline IFAD and $C A F$ & 9.0 & 0.0 & 1.7 & 0.8 & 2.5 & -0.6 & 6.7 \\
\hline Bilateral & 858.0 & 27.8 & 30.4 & 38.7 & 250.4 & -112.1 & 562.0 \\
\hline Paris Club 3/ & 400.2 & 3.4 & 17.6 & 21.6 & 39.2 & -0.6 & 385.4 \\
\hline Venezuela and Mexico & 299.2 & 0.0 & 12.8 & 9.6 & 203.7 & -105.1 & 0.0 \\
\hline Support Group & 83.3 & 24.4 & 0.0 & 4.8 & 4.8 & -6.4 & 101.3 \\
\hline Taiwan $4 /$ & 75.3 & 0.0 & 0.0 & 2.7 & 2.7 & 0.0 & 75.3 \\
\hline $\begin{array}{c}\text { Commercial } \\
\text { Of which: }\end{array}$ & $4,193.6$ & 0.0 & 75.0 & 158.4 & 230.0 & -397.8 & $3,724.2$ \\
\hline Brady bonds & $3,761.1$ & 0.0 & 0.0 & 127.2 & 114.4 & -488.7 & $3,285.2$ \\
\hline Other bonds & 432.5 & 0.0 & 67.0 & 28.7 & 96.4 & 0.6 & 365.4 \\
\hline Commercial banks credit lines & 0.0 & 0.0 & 8.0 & 2.5 & 19.2 & 90.3 & 73.6 \\
\hline \multirow[t]{3}{*}{ Suppliers $5 /$} & 44.0 & 0.0 & 9.1 & 2.7 & 11.8 & 0.1 & 35.0 \\
\hline & & \multicolumn{5}{|c|}{ Operations in 1997} & \\
\hline & $\begin{array}{c}\text { Out- } \\
\text { standing } \\
12 / 31 / 96\end{array}$ & Drawings & $\begin{array}{l}\text { Amort- } \\
\text { ization } \\
\text { Due } \\
\end{array}$ & $\begin{array}{l}\text { Interest } \\
\text { Due }\end{array}$ & Payments & $\begin{array}{c}\text { Adjust- } \\
\text { ments } 2 /\end{array}$ & $\begin{array}{c}\text { Out- } \\
\text { standing } \\
12 / 31 / 97\end{array}$ \\
\hline Total & $5,127.2$ & $1,486.4$ & $1,227.5$ & 282.3 & $1,541.9$ & -273.7 & $5,080.3$ \\
\hline Multilateral & 806.0 & 247.1 & 97.0 & 42.1 & 139.2 & -22.6 & 933.4 \\
\hline $\mathbb{M} F$ & 130.9 & 45.8 & 26.1 & 7.5 & 33.6 & -8.4 & 142.2 \\
\hline IBRD & 198.7 & 54.5 & 29.2 & 13.8 & 43.1 & 5.7 & 229.6 \\
\hline DB & 469.7 & 144.6 & 39.8 & 20.3 & 60.0 & -19.9 & 554.7 \\
\hline IFAD and CAF & 6.7 & 2.2 & 1.9 & 0.5 & 2.5 & 0.0 & 6.9 \\
\hline Bilateral & $\$ 62.0$ & 39.3 & $\$ 8.8$ & 28.0 & 86.8 & -17.8 & 524.7 \\
\hline Paris Club 3f & 385.4 & 7.7 & 55.6 & 19.9 & 75.5 & -4.4 & 333.1 \\
\hline Venezuela and Mexico & 0.0 & 0.0 & 0.0 & 0.0 & 0.0 & 0.0 & 0.0 \\
\hline Support group & 101.3 & 31.6 & 1.6 & 5.4 & 7.0 & -13.4 & 117.9 \\
\hline Taiwan 4/ & 75.3 & 0.0 & 1.6 & 2.7 & 4.3 & 0.0 & 73.7 \\
\hline $\begin{array}{l}\text { Commercial } \\
\text { Of which: }\end{array}$ & $3,724.2$ & $1,200.0$ & $1,068.0$ & 211.3 & $1,312.3$ & .229 .9 & $3,593.3$ \\
\hline Brady bonds & $3,285.2$ & 0.0 & 991.4 & 161.8 & $1,189.8$ & -229.3 & $2,027.9$ \\
\hline Other bonds & 365.4 & $1,200.0$ & 66.0 & 43.3 & 109.3 & -0.7 & $1,498.7$ \\
\hline Commercial banks credit lines & 73.6 & 0.0 & 10.6 & 6.2 & 13.2 & 0.1 & 66.7 \\
\hline Suppliers 5/ & 35.0 & 0.0 & 5.2 & 2.7 & 7.9 & -0.9 & 28.9 \\
\hline
\end{tabular}


Table 49 Panama: Operations on Medium- and Long-Term External Debt of the Nonfinancial Public Sector (Continued)

(In millions of balboas)

\begin{tabular}{|c|c|c|c|c|c|c|c|}
\hline & \multirow[b]{2}{*}{$\begin{array}{c}\text { Out- } \\
\text { statiditig } \\
12 / 31 / 97 \\
\end{array}$} & \multicolumn{5}{|c|}{ Operations in 1998} & \multirow[b]{2}{*}{$\begin{array}{c}\text { Out- } \\
\text { standing } \\
12 / 31 / 98\end{array}$} \\
\hline & & Drawings & $\begin{array}{l}\text { Amort- } \\
\text { ization } \\
\text { Due }\end{array}$ & $\begin{array}{c}\text { Interest } \\
\text { Due }\end{array}$ & Payments & $\begin{array}{l}\text { Adjust- } \\
\text { ments } 21\end{array}$ & \\
\hline Total & $5,080.2$ & 700.2 & 308.7 & 308.9 & 597.9 & -78.6 & $5,415.8$ \\
\hline Multilateral & 933,4 & 273.1 & 72,3 & 47.9 & 120.2 & 12.3 & $1,146.5$ \\
\hline $\mathbb{I M F}$ & 142.2 & 41.5 & 13.3 & 8.1 & 21.4 & 0.0 & 170.4 \\
\hline IBRD & 229.6 & 91.3 & 25.9 & 14.5 & 40.4 & $-7,0$ & 288.0 \\
\hline IDB & 554,7 & 133.1 & 31.2 & 24.7 & 55.9 & 17.2 & 673.8 \\
\hline IFAD and CAF & 6.9 & 7.2 & 1.9 & 0.6 & 2.4 & 2.1 & 14.3 \\
\hline Bilateral & 524.7 & 97.0 & 64.0 & 23.3 & 87.3 & -34.2 & 523.5 \\
\hline Paris Club 3/ & $3,33,1$ & 82.5 & 56.4 & 16.9 & 73.3 & -46.0 & 313.2 \\
\hline Venezuela and Mexico & 0.0 & 0.0 & 0.0 & 0.0 & 0.0 & 0.0 & 0.0 \\
\hline Support Group & 117.9 & 14.5 & 1.6 & 3.8 & 5.4 & 11.8 & 142.6 \\
\hline Taiwan $4 /$ & 73.7 & 0.0 & 6.0 & 2.6 & 8.6 & 0.0 & 67.7 \\
\hline $\begin{array}{l}\text { Commercial } \\
\text { Of which: }\end{array}$ & $3,593.3$ & 333.0 & 168.0 & 235.8 & 384,1 & -32.8 & $3,745.2$ \\
\hline Brady bonds & $2,027.9$ & 0.0 & 58.1 & 99.1 & 138.1 & -23.9 & $1,965.0$ \\
\hline Other bonds & $1,498.7$ & $\mathbf{3 3 3 . 0}$ & 65.5 & 134.6 & 199.6 & $-4,2$ & $1,762.5$ \\
\hline Conmercial banks credit lines & 66.7 & 0.0 & 44.4 & 2.1 & 46.4 & -4.7 & 17.7 \\
\hline \multirow[t]{3}{*}{ Suppliers St } & 28.9 & 0.0 & 4.4 & 1.9 & 6.3 & -23.9 & 0.6 \\
\hline & & \multicolumn{5}{|c|}{1999} & \\
\hline & $\begin{array}{c}\text { Out- } \\
\text { standing } \\
12 / 31 / 98\end{array}$ & Drawings & $\begin{array}{l}\text { Amort- } \\
\text { ization } \\
\text { Due }\end{array}$ & $\begin{array}{c}\text { Interest } \\
\text { Due }\end{array}$ & Payments & $\begin{array}{l}\text { Adjust- } \\
\text { ments 2! }\end{array}$ & $\begin{array}{c}\text { Out- } \\
\text { standing } \\
12 / 3199 \\
\end{array}$ \\
\hline Total & $5,415,8$ & 634.5 & 413.6 & 370.7 & 752.6 & -35.6 & $5,6.32 .8$ \\
\hline Multilateral & $1,146.5$ & 79.4 & 75.6 & 81.0 & 142.5 & 2.4 & $3,366.8$ \\
\hline $\mathrm{IMF}$ & 170.4 & 0.0 & 23.2 & 6.5 & 29.8 & 1.6 & 348.7 \\
\hline IBRD & 288.0 & 31.1 & 21.7 & 19.1 & 40.7 & 0.0 & 297.5 \\
\hline IDB & 673.8 & 38.3 & 28.3 & 53.8 & 67.2 & 0.1 & 698.8 \\
\hline IFAD and CAF & 14.3 & 10.0 & 2.4 & 1.6 & 4.8 & 0.7 & 21.8 \\
\hline Bilateral & 523.5 & 47.9 & 71.1 & 23.4 & 94.0 & -0.6 & 500.2 \\
\hline Paris Club 3/ & 313.2 & 43.4 & 57.3 & 16.7 & 73.5 & -0.6 & 299.2 \\
\hline Venezuela and Mexico & 0.0 & 0.0 & 0.0 & 0.0 & 0.0 & 0.0 & 0.0 \\
\hline Support Group & 142.6 & 0.0 & 7.8 & 4.2 & 12.0 & 0.0 & 134.8 \\
\hline Taiwan $4 !$ & 67.7 & 4.5 & 6.0 & 2.5 & 8.5 & 0.0 & 66.2 \\
\hline $\begin{array}{l}\text { Commercial } \\
\text { Of which: }\end{array}$ & $3,745.2$ & 507.2 & 266.5 & 266.2 & 515.6 & -37.4 & $3,965.6$ \\
\hline Brady bonds & $1,965.0$ & 0.0 & 161,4 & 95.3 & 239.7 & -390 & $1,781.6$ \\
\hline Other bonds & $1,762.5$ & 499.6 & 98.8 & 168.6 & 267.4 & 2.1 & $2,165.4$ \\
\hline Commercial banks credit lines & 17.7 & 7.6 & 6.3 & 2.3 & 8.5 & -0.5 & 18.6 \\
\hline Suppliers 5/ & 0.6 & 0.0 & 0.4 & 0.1 & 0.5 & 0.0 & 0.2 \\
\hline
\end{tabular}


Table 49. Panama: Operations on Medium- and Long-Term External Debt of the Nonfinancial Public Sector (Concluded)

(In millions of balbaas)

\begin{tabular}{|c|c|c|c|c|c|c|c|}
\hline & \multirow[b]{2}{*}{$\begin{array}{c}\text { Out- } \\
\text { standing } \\
12 / 31 / 99\end{array}$} & \multicolumn{5}{|c|}{ January-September 2000} & \multirow[b]{2}{*}{$\begin{array}{c}\text { Ont- } \\
\text { standing } \\
9 / 30 / 00\end{array}$} \\
\hline & & Drawings & $\begin{array}{l}\text { Amort- } \\
\text { ization } \\
\text { Due }\end{array}$ & $\begin{array}{l}\text { Interest } \\
\text { Due }\end{array}$ & Payments & $\begin{array}{l}\text { Adjust- } \\
\text { ments 2/ }\end{array}$ & \\
\hline Total & $5,632.8$ & 448.2 & 209.1 & 312.5 & 630.7 & -61.9 & $5,700.9$ \\
\hline Multilateral & $1,166.8$ & 51.1 & 82.6 & 56.8 & 134.8 & -37.7 & $1,102.2$ \\
\hline $\mathbb{M} \mathbf{F}$ & 148.7 & 0.0 & 38.1 & 4.0 & 42.2 & -7.2 & 109.3 \\
\hline IBRD & 297.5 & 14.0 & 18.8 & 15.5 & 34.4 & -10.5 & 282.1 \\
\hline IDB & 698.8 & 32.1 & 24.1 & 35.0 & 54,3 & -18.5 & 693.1 \\
\hline IFAD and $C A F$ & 21.8 & 5.0 & 1.6 & 2.3 & 3.9 & -1.5 & 23.7 \\
\hline Bilateral & 500.2 & 17.5 & 63.7 & 18.6 & 822 & -5.0 & 449.1 \\
\hline Paris Club 3/ & 299.2 & 17.5 & 53.3 & 13.4 & 66.7 & 1.4 & 264.8 \\
\hline Venezuela and Mexico & 0.0 & 0.0 & 0.0 & 0.0 & 0.0 & 0.0 & 0.0 \\
\hline Support Group & 134.8 & 0.0 & 7.4 & 3.9 & 11.2 & -6.3 & 121.2 \\
\hline Taiwan 4/ & 66.2 & 0.0 & 3,0 & 1.3 & 4.3 & -0.1 & 63.1 \\
\hline $\begin{array}{l}\text { Commercial } \\
\text { Of which: }\end{array}$ & $3,965.6$ & 379.6 & 62.6 & 237.1 & 413.5 & -19.2 & $4,149.6$ \\
\hline Brady bonds & $1,781.6$ & 0.0 & 0.0 & 76.2 & 176.3 & -33.4 & $1,648.1$ \\
\hline Other bonds & $2,165.4$ & 350.0 & 33.3 & 160.1 & 203.0 & 10.7 & $2,483.2$ \\
\hline Commercial banks credit lines & 18.6 & 29.6 & 29.3 & 0.8 & 34.2 & 3.5 & 18.3 \\
\hline Suppliers 5/ & 0.2 & 0.0 & 0.2 & 0.0 & 0.2 & 0.0 & 0.0 \\
\hline
\end{tabular}

Sources: Ministry of Planning and Economic Policy; National Bank of Panama; IMF; IDB; BRD; and Fund staff estimates.

1/ Excluding short-term debt. Figures include interest arrears.

2/ Adjustments dive to valuation changes, data revisions, and/or debt reduction

$3 /$ Includes insured suppliers' credit.

4/ Debt of the National Bank of Panarna

5/Noninsured suppliers' credits only. 
Table 50. Panama: Arrears on Public Sector External Debt Service

(In millions of balboas; end of period)

\begin{tabular}{|c|c|c|c|c|c|c|c|c|c|c|c|c|}
\hline & \multicolumn{2}{|c|}{1994} & \multicolumn{2}{|c|}{1995} & \multicolumn{2}{|c|}{1996} & \multicolumn{2}{|c|}{1997} & \multicolumn{2}{|c|}{1998} & \multicolumn{2}{|c|}{1999} \\
\hline & Principal & Interest & Principal & Interest & Principal & Interest & Principal & Interest & Principal & $\overline{\text { Tnterest }}$ & Principal & Interest \\
\hline Total & $1,927.2$ & $1,598.9$ & $1,954,8$ & $1,983.3$ & 51.5 & 45.8 & 21.3 & 19.9 & 0.0 & 0.0 & 0.0 & 0,0 \\
\hline $\begin{array}{l}\text { Commercial banks } \\
\text { Of which: }\end{array}$ & $1,800.2$ & $1,478,6$ & $1,817.9$ & $1,841.1$ & 48.8 & 44.0 & 20.0 & 19.2 & 0.0 & 0.0 & 0.0 & 0.0 \\
\hline Short-term debt $1 /$ & 72.0 & 42.1 & 28.1 & 34.0 & 20.0 & 15.2 & 20.0 & 19.2 & 0.0 & 0.0 & 0.0 & 0.0 \\
\hline Bonded debt & 2.3 & 0.7 & 2.5 & 0.7 & 1.4 & 1.1 & 0.0 & 0.0 & 0.0 & 0.0 & 0.0 & 0.0 \\
\hline Mexico and Ventezuela & 121.2 & 117.2 & 133.1 & 140.5 & 0.0 & 0.0 & 0.0 & 0.0 & 0.0 & 0.0 & 0.0 & 0.0 \\
\hline Suppliers & 3.5 & 2.4 & 1.3 & 1.0 & 1.3 & 0.7 & 1.3 & 0.7 & 0.0 & 0.0 & 0.0 & 0.0 \\
\hline
\end{tabular}

Sources: Ministry of Planning and Economic Policy; IMF; IDB; IBRD; and Fund staff estimates.

$1 /$ Consists of credit lines to public enterprises and money facilities of the National Bank. 